\title{
Renewable Energy Opportunities at Fort Hood, Texas
}

$\begin{array}{lll}\text { WD Chvala } & \text { AE Solana } & \text { RW Reilly } \\ \text { WM Warwick } & \text { MR Weimar } & \\ \text { DR Dixon } & \text { JC States } & \end{array}$

June 2008

Pacific Northwest

NATIONAL LABORATORY

Proudly Operated by Battelle Since 1965 


\title{
DISCLAIMER
}

This report was prepared as an account of work sponsored by an agency of the United States Government. Neither the United States Government nor any agency thereof, nor Battelle Memorial Institute, nor any of their employees, makes any warranty, express or implied, or assumes any legal liability or responsibility for the accuracy, completeness, or usefulness of any information, apparatus, product, or process disclosed, or represents that its use would not infringe privately owned rights. Reference herein to any specific commercial product, process, or service by trade name, trademark, manufacturer, or otherwise does not necessarily constitute or imply its endorsement, recommendation, or favoring by the United States Government or any agency thereof, or Battelle Memorial Institute. The views and opinions of authors expressed herein do not necessarily state or reflect those of the United States Government or any agency thereof.

\author{
PACIFIC NORTHWEST NATIONAL LABORATORY \\ operated by \\ BATTELLE \\ for the \\ UNITED STATES DEPARTMENT OF ENERGY \\ under Contract DE-AC05-76RL01830
}

Printed in the United States of America
Available to DOE and DOE contractors from the
Office of Scientific and Technical Information,
P.O. Box 62, Oak Ridge, TN 37831-0062;
ph: (865) 576-8401
fax: (865) 576-5728
email: reports@adonis.osti.gov

\footnotetext{
Available to the public from the National Technical Information Service,

U.S. Department of Commerce, 5285 Port Royal Rd., Springfield, VA 22161

ph: (800) 553-6847

fax: $(703) 605-6900$

email: orders@ntis.fedworld.gov

online ordering: http://www.ntis.gov/ordering.htm
}

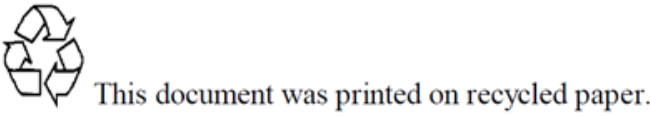

$(9 / 2003)$ 


\section{Renewable Energy Opportunities at Fort Hood, Texas}

$\begin{array}{lll}\text { WD Chvala } & \text { AE Solana } & \text { RW Reilly } \\ \text { WM Warwick } & \text { MR Weimar } & \\ \text { DR Dixon } & \text { JC States } & \end{array}$

June 2008

Prepared for the

U.S. Army Installation Management Command Headquarters

under Contract DE-AC05-76RL01830

Related Services

Pacific Northwest National Laboratory

Richland, Washington 99352 



\section{Executive Summary}

Energy has become an increasingly expensive component of military operations in the United States and abroad. The Department of Defense (DoD) identified renewable resource options and alternatives for domestic facilities in its Renewable Energy Assessment Final Report and associated Implementation Plan in 2005. Based on those results, DoD established a goal of obtaining 25\% of its domestic electricity from renewable sources by 2025. At the time, this was a stretch goal that pushed DoD beyond the renewable mandates in Executive Order 13123, which DoD was already exceeding. Since that time, new renewable mandates and schedules have been established in the Energy Policy Act of 2005 (EPAct) and in Executive Order 13423. In addition, the DoD renewables goal was formalized in the National Defense Authorization Act (NDAA) of 2007. The $110^{\text {th }}$ Congress (January 2007 through January 2009) considered increasing federal renewable energy goals to levels near those adopted by DoD in 2007. This provision was eliminated before passage of The Energy Independence and Security Act of 2007 (EISA). The issue is, however, likely to be reconsidered by Congress in the future.

The Army has numerous compelling reasons to substitute renewable energy for conventional energy procurements at its installations and facilities, including:

$\checkmark$ Reducing energy costs and energy cost volatility,

$\checkmark$ Enhancing supply reliability by utilizing local indigenous generating sources,

$\checkmark$ Increasing resilience and endurance through development of on-site renewable resources,

$\checkmark$ Exposing soldiers to renewable technologies that will be deployed in theater, and

$\checkmark$ Complying with applicable laws and policies.

This document provides an overview of renewable resource potential at Fort Hood based primarily upon analysis of secondary data sources supplemented with limited on-site evaluations. The effort was funded by the U.S. Army Installation Management Command (IMCOM) as follow-on to the 2005 DoD Renewables Assessment. This effort focuses on grid-connected generation of electricity from renewable energy sources and also ground source heat pumps for heating and cooling buildings, as directed by IMCOM.

This report creates a roadmap for focusing the installation's efforts on realistic projects, moving them from initial assessment through the design and financing to implementation. Implementation approaches are recommended for each economically viable technology. This report is a first step, but not the only step, towards meeting Fort Hood's renewable energy goals.

At the current time there are several renewable technologies that show economic potential at Fort Hood (see Table 1). These include electricity generation from wind and waste-to-energy plants, and retrofit of existing buildings with ground source heat pumps.

Wind-generated electricity on Fort Hood is a possibility. The cost of production is close to the cost of commercial power currently provided by Constellation Energy, and wind generation is likely to become more competitive as commercial electricity costs increase in the future. Horizon Wind, which is developing other wind projects in Texas, is interested in discussions with Fort Hood for either Hood's purchase of energy generated just off post, or for developing wind projects on Fort Hood. 
There are several viable approaches for establishing a waste-to-energy plant. The Fort is already talking to the City of Killeen and ZEROS, Inc. (developer of the zero-emission energy recycling oxidation system) about a 39-MWe plant based upon a proprietary technology. Should this opportunity falter, there are other waste-to-energy projects that might prove feasible using more conventional technologies. All of these projects, however, will be feasible only if there is an adequate supply of municipal and/or other wastes to fuel the plants. Enough waste is generated regionally-but is it available to the Fort, and if so, at what cost? Should the Fort decide to pursue these other options, the first step should be to confirm the availability and cost of delivering this waste onto the post.

Retrofit of heating, ventilation and air conditioning (HVAC) systems in existing buildings with ground source heat pumps (GSHPs) was assessed for every building on post. Open-loop systems, where groundwater is used directly as the heat transfer medium, were found to be cost effective for two large buildings, an administrative building (building 1001) and the PX (building 50004). Closed-loop GSHPs were found to be cost effective for 67 additional buildings. These buildings were either all-electric (heating and cooling) or benefitted from the abandonment of existing distribution lines. If retrofits are realized in all 69 of these buildings, about 20,924 MMBtus could be saved per year. The next step is a physical assessment of available heat sources and sinks (water in the case of open-loop systems, and adequate land space and suitable soil characteristics in the case of closed-loop systems).

Solar and geothermal electricity generation opportunities were also investigated in this analysis. Electricity generation is not cost effective from either of these potential resources-either because of a lack of a viable resource (geothermal) or inability to compete against the cost of commercial power being sold to Fort Hood (solar). Solar may find niche applications for direct use at remote applications, but substantial increases in commercial energy rates are required before it can be economic for gridconnected power generation. 
Table 1: Summary of Promising Renewable Energy Projects at Fort Hood

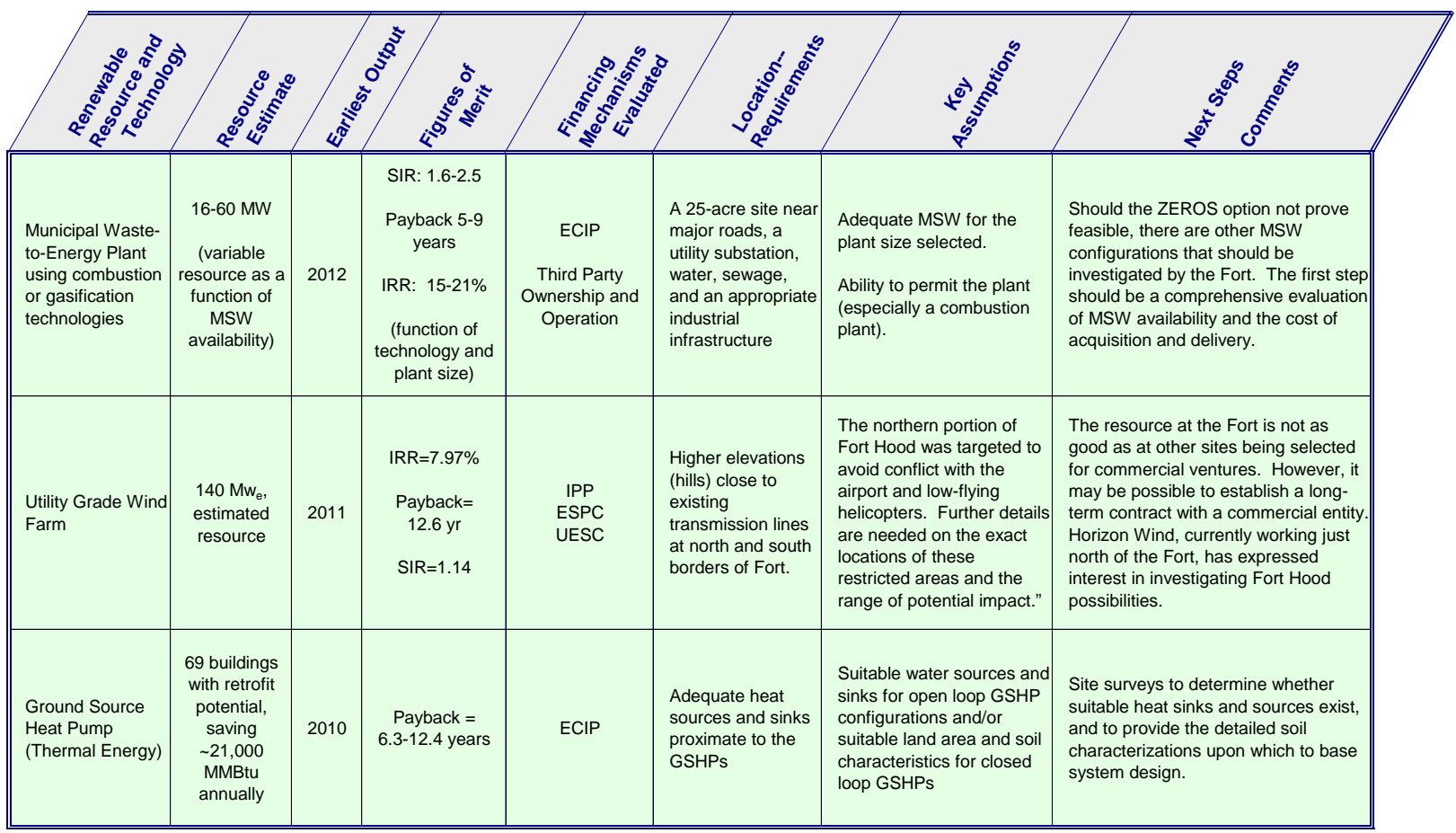

SIR = savings-to-investment ratio

IRR = Internal Rate of Return

ECIP $=$ Energy Conservation Investment Program

IPP $=$ independent power producer

UESC = Utility Energy Services Contract

ESPC $=$ Energy Savings Performance Contract

MSW $=$ municipal solid waste

WTE = waste-to-energy

GSHP = Ground Source Heat Pumps

Increasing use of renewable energy makes sense for the Army. The goal of this report is to help Army personnel make sense of renewable energy at Fort Hood. 


\section{Table of Contents}

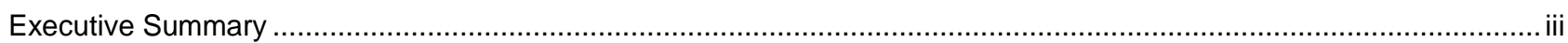

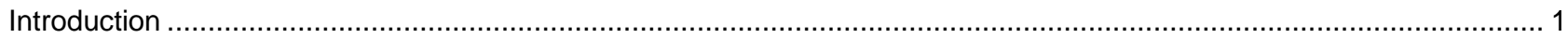

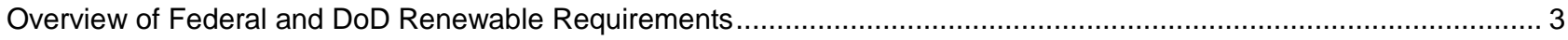

Analysis of Renewables at Fort Hood . . . .

Approach for Identifying, Analyzing, and Implementing Renewable Energy Projects .................................. 5

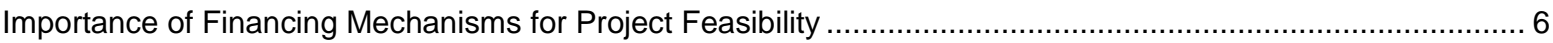

The Political and Economic Environment for Renewables at Fort Hood ................................................... 7

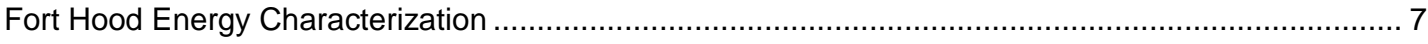

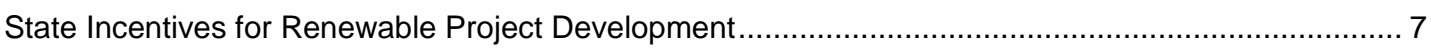

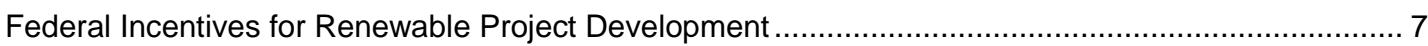

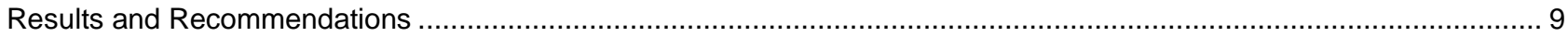

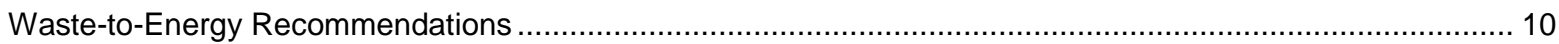

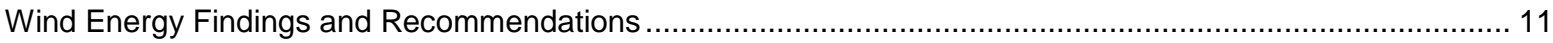

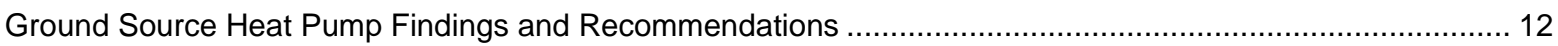

Geothermal Power Plant Findings and Recommendations........................................................... 13

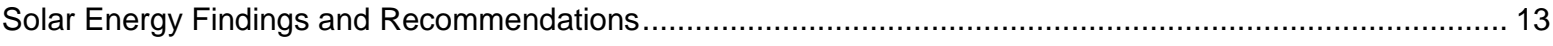

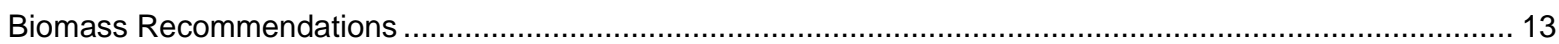

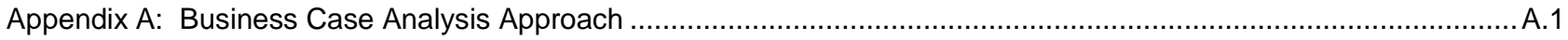

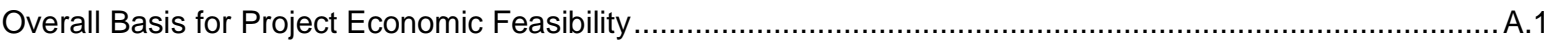

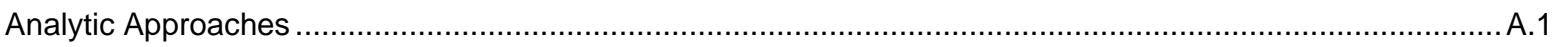

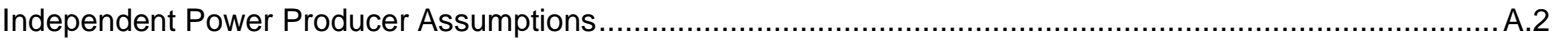

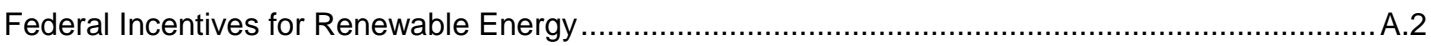

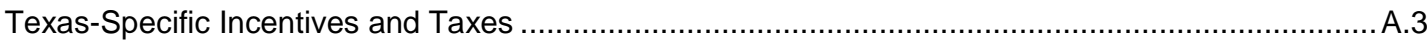

Other Independent Power Producer Assumptions............................................................. A. 3

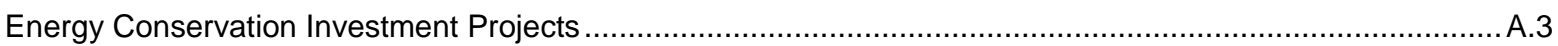

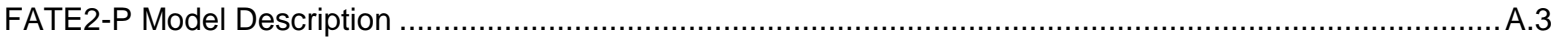

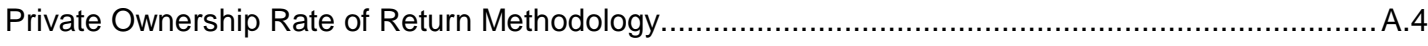

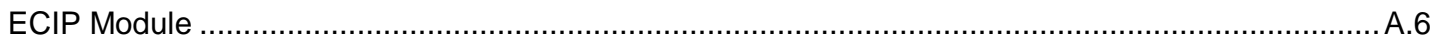

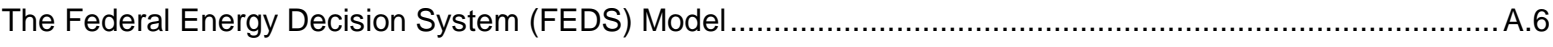

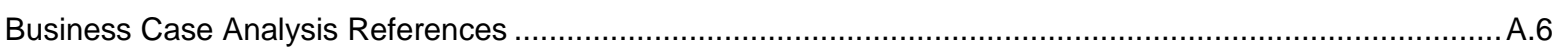

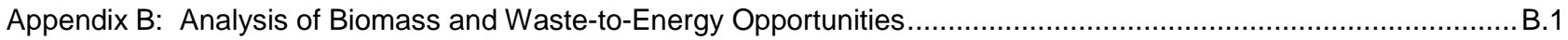

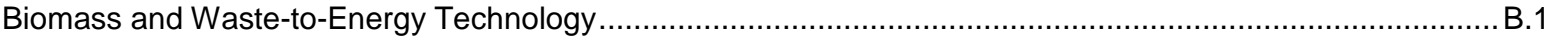

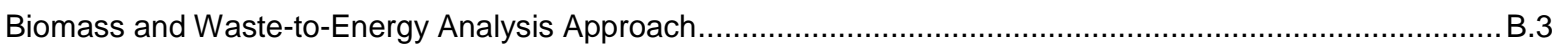

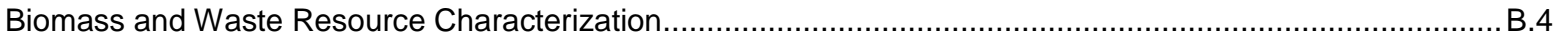

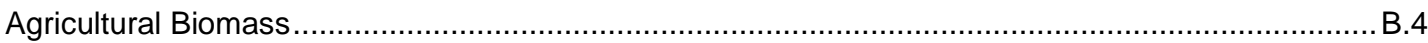

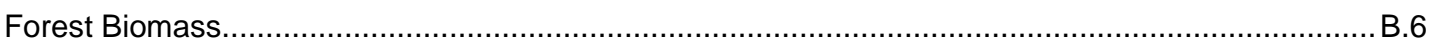

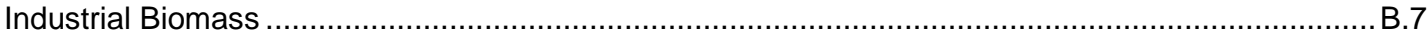

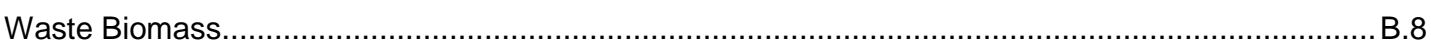


Biomass and Waste-to-Energy: Economic and Other Analysis Parameters

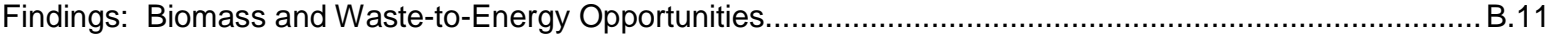

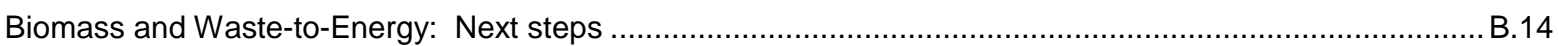

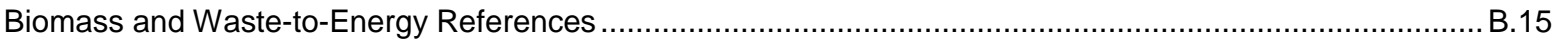

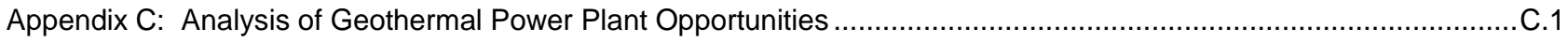

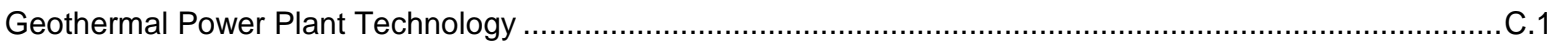

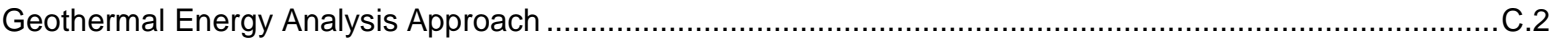

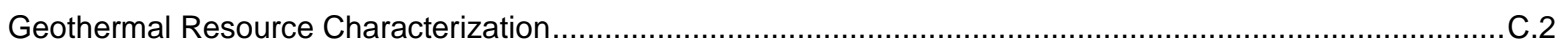

Geothermal Power Plants: Economic and Other Analysis Parameters.................................................

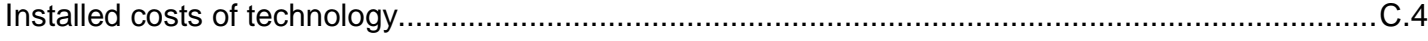

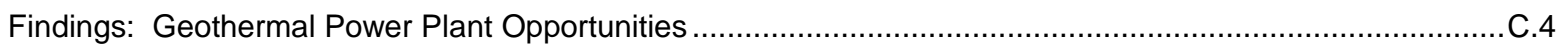

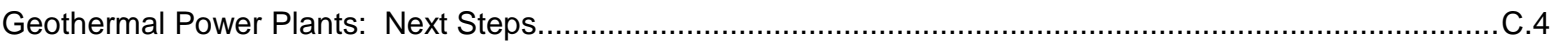

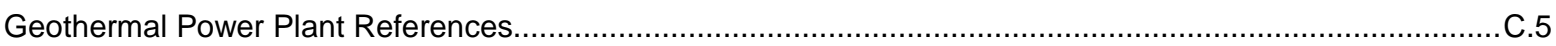

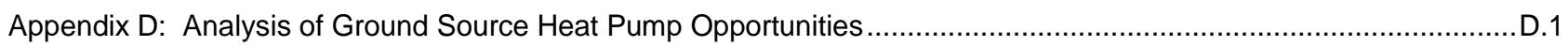

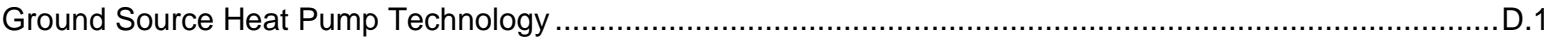

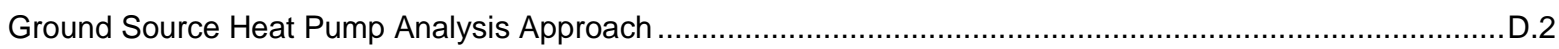

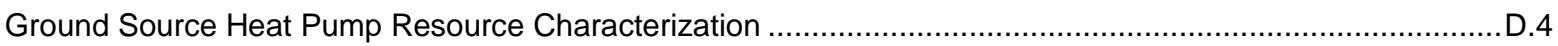

Ground Source Heat Pump: Economic and Other Analysis Parameters .............................................. D.5

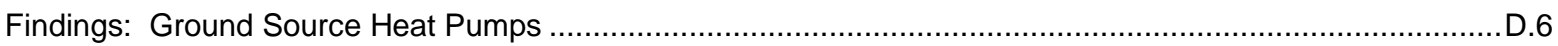

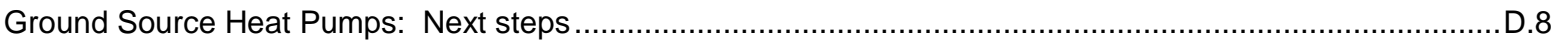

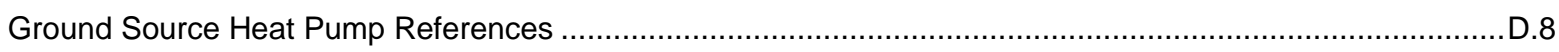

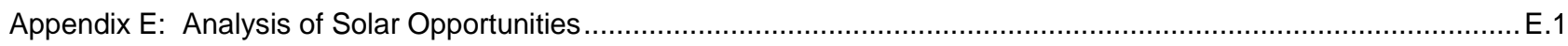

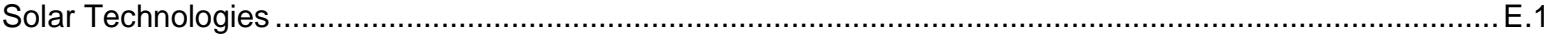

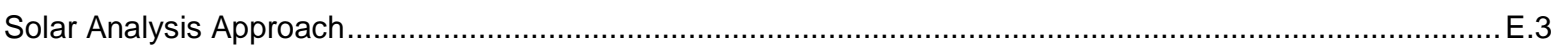

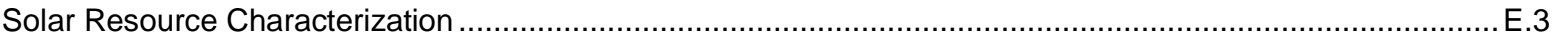

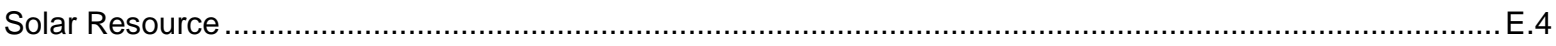

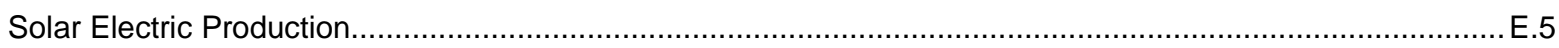

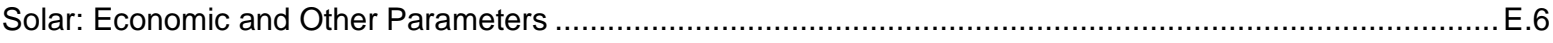

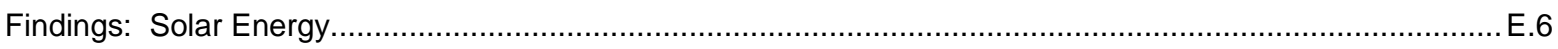

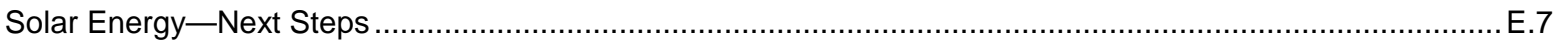

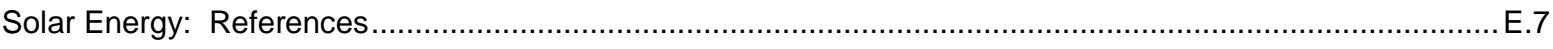

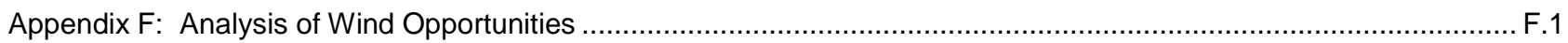

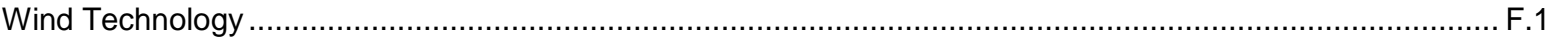

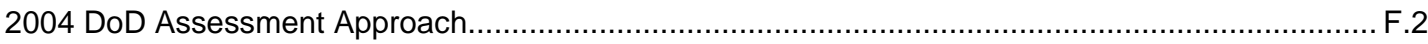

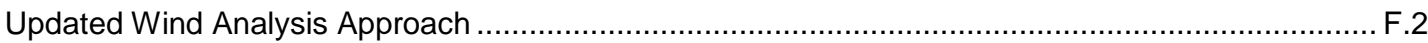

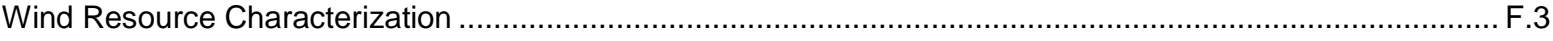

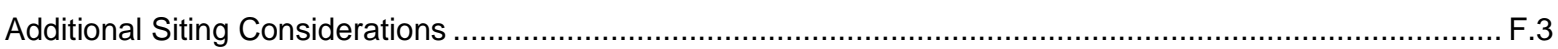

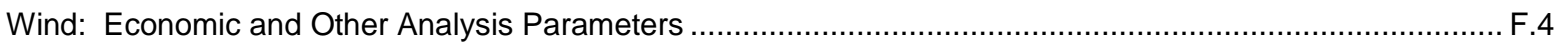

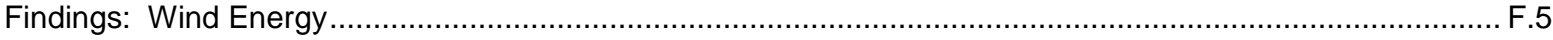




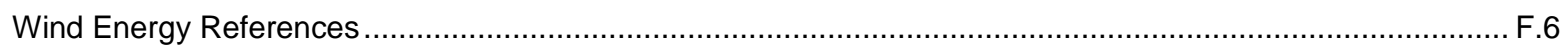




\section{Figures}

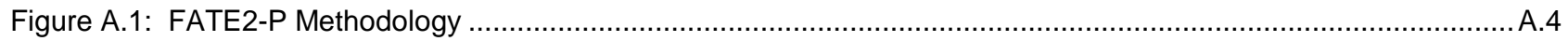

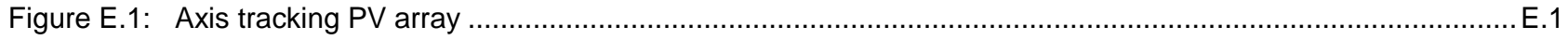

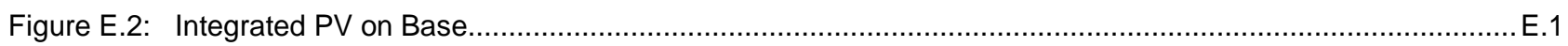

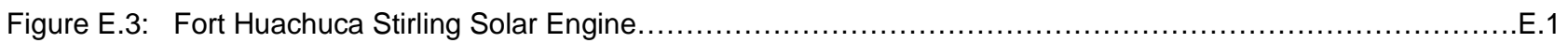

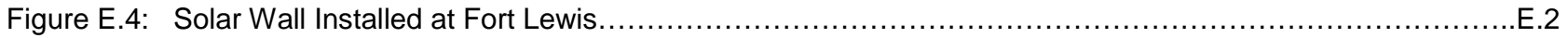

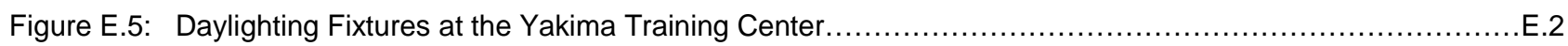

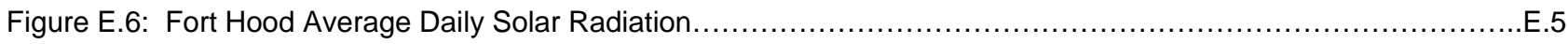

Figure F.1: Location of Transmission Lines in Relation to Fort Hood............................................................... F.4

\section{Tables}

Table 1: Summary of Promising Renewable Energy Projects at Fort Hood ............................................................

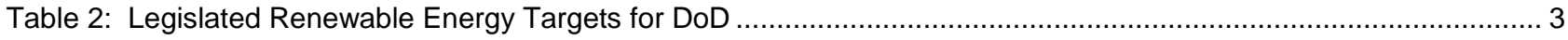

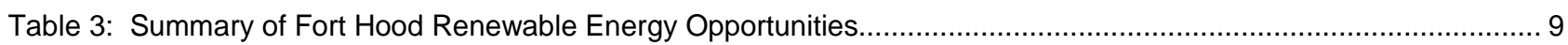

Table 4: MSW Waste-to-Energy Results for Combustion Technologies ........................................................... 10

Table 5: MSW Waste-to-Energy Results for Gasification and Plasma Melting Technologies ..................................... 11

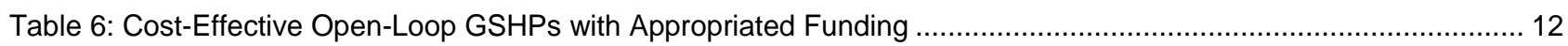

Table 7: Cost-Effective Closed-Loop GSHPs with Appropriated Funding …........................................................ 13

Table 8: Fort Hood Buildings with the Potential for Cost-Effective GSHP Retrofit..................................................... 13

Table A.1: MACRS Depreciation Rates for Renewable Energy Projects .............................................................

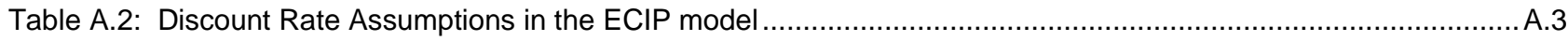

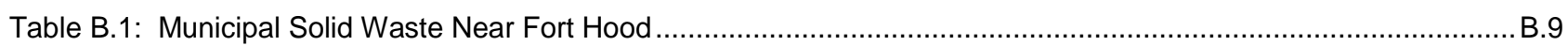

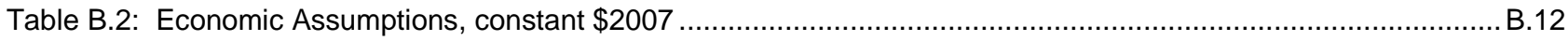

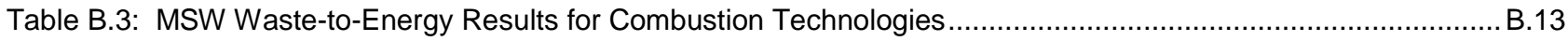

Table B.4: MSW Waste-to-Energy Results for Gasification and Plasma Melting Technologies................................ B.14

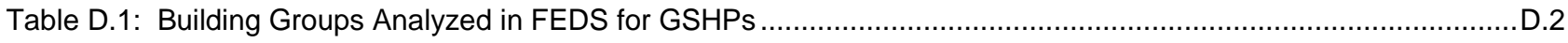

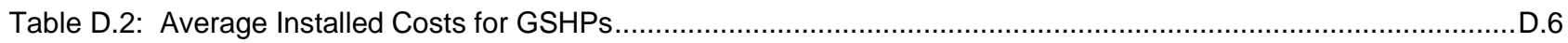

Table D.3: Economic Evaluation of GSHP Opportunities at Fort Hood Empty cells identify HVAC combinations where no

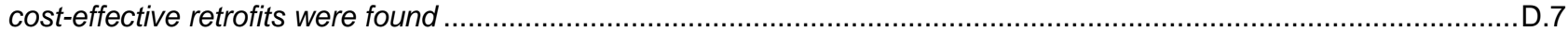

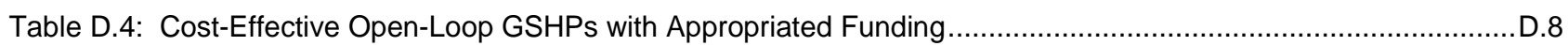

Table D.5: Cost-Effective Closed-Loop GSHPs with Appropriated Funding ….................................................... D.8

Table D.6: Fort Hood Buildings with the Potential for Cost-Effective GSHP Retrofit ............................................D.8

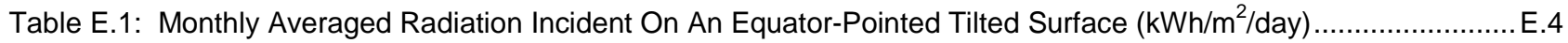




\section{Introduction}

Pacific Northwest National Laboratory (PNNL) has been directed by the U.S. Army Installation Management Command (IMCOM) to conduct detailed analyses of the potential for electricity generation at selected U.S. Army installations. The goal of the analyses is to identify economically feasible opportunities for generation of electricity from renewables-generation that is significant enough to warrant connection to the grid and/or to contribute in a meaningful way to the aggressive renewable energy goals of the Army and the Department of Defense.

In 2005, PNNL led a study to identify utility-scale electricity generation opportunities at Department of Defense installations. That study focused on solar, wind, and geothermal. A limited number of attractive large-scale commercial opportunities were identified and their implementation is now being pursued. The study also identified a number of potential smaller opportunities that needed to be investigated further before project implementation decisions could be made.

This analysis of opportunities at Fort Hood is one of a suite of analyses being conducted at Army installations as follow-on to the 2005 study. Its goal is to revisit potential renewable opportunities, updating the analysis for changes in economics, incentives, knowledge about the available renewable resource, and other factors. In addition, IMCOM has directed PNNL to evaluate the potential for retrofitting heating, ventilation and air conditioning (HVAC) systems in existing buildings with ground source heat pumps. This is obviously not an electricity generation opportunity, but it is an opportunity for significant energy savings across the DoD. As part of the analysis, IMCOM has directed PNNL to lay out the steps necessary to implement the project opportunities that are identified.

The overall findings of this analysis are summarized in the main body of the report. The business case approach that underlies the analysis of each renewable technology is documented in Appendix A. Appendix B describes the analysis conducted on biomass and waste-to-energy technologies. Appendix $\mathrm{C}$ describes the geothermal analysis; Appendix D, the ground source heat pump analysis; Appendix E, the solar analysis; and Appendix F, the wind energy analysis. 


\section{Overview of Federal and DoD Renewable Requirements}

The Army needs to satisfy multiple goals and constraints while securing its energy supplies_-focusing upon procurement of the lowest-cost energy that meets high reliability standards and minimum vulnerability to interruption from natural or intentional causes. Overlaid on this challenge is the need to comply with a series of somewhat contradictory statutes and policies, as laid out in Table 2 . These include:

$\checkmark \quad$ EPAct Section 203. This law mandates the minimum contribution of renewable energy to an installation's total electricity consumption. The target fractions are; 3\% for FY 2007 through FY 2009, 5\% through FY 2012, and not less than 7.5 \% beginning in FY 2013. Recently proposed legislation, Senate Bill 1321, would increase these goals to 10\% by FY 2010 and 15\% by FY 2015. Although the bill has become law as the EISA, the renewable energy provisions were not included in the final version. It is likely this provision will be reintroduced in energy legislation in the next Congress.

$\checkmark$ Executive Order 13423. The Executive Order reiterates the EPAct goals; however it uses a different basis for measuring and crediting progress than EPAct.

$\checkmark$ The National Defense Authorization Act (NDAA). The NDAA codifies DoD's voluntary goal of $25 \%$ of total energy from renewables by 2025, but doesn't include any interim targets.

Table 2: Legislated Renewable Energy Targets for DoD

\begin{tabular}{||r|c|c|c||}
\hline \hline & EPAct Section 203 & $\begin{array}{c}\text { Executive Order } \\
\mathbf{1 3 4 2 3}\end{array}$ & $\begin{array}{c}\text { National Defense } \\
\text { Authorization Act } \\
\text { (2007) }\end{array}$ \\
\hline \hline Target/Goal & $\begin{array}{c}\text { Increasing targets reaching } \\
7.5 \% \text { renewable content of } \\
\text { electricity consumed }\end{array}$ & $\begin{array}{c}\text { At least 7.5\% of electric } \\
\text { energy from new } \\
\text { renewable energy with } \\
50 \% \text { from new sources } \\
\text { (after 1998) }\end{array}$ & $\begin{array}{c}25 \% \text { of total energy } \\
\text { from Renewable } \\
\text { Energy Sources }\end{array}$ \\
\hline Target Dates & 2013 & 2013 & 2025 \\
\hline Mandatory? & Yes & Yes & No \\
\hline Considers thermal \\
energy "renewable?"
\end{tabular}

Although DoD would like a single set of requirements and guidelines, that is not the current situationthere are still multiple goals and somewhat conflicting oversight documents. The Department of Energy is responsible for developing guidance for EPAct and EO 13423. The previous Executive Order, EO 13123, had an expansive view of renewable energy. It allowed renewable energy that displaced conventional energy other than electricity to be credited as electricity savings. In other words, thermal energy saved from use of ground source heat pumps was treated as a reduction in electricity from conventional sources. However, the language in EPAct has a narrower definition. It specifies that the reduction must be from “electricity used.” DOE's current interpretation is that renewable energy that is not electricity, such as solar thermal energy, daylighting, or ground source heat pumps, cannot be credited towards the EPAct goals. DOE's guidelines for EO compliance allow credit for renewable energy that reduces electricity use from thermal sources; however, it adds a requirement that at least 
$50 \%$ of renewable energy must come from "new" resources (those put into service after January 1, 1999). Congress did not provide a definition of "renewable" in the NDAA language, and DOE is not responsible for establishing DoD or Army policies to achieve the goals in the NDAA. The current Army energy strategy and associated draft renewable policy takes an expansive view of renewables, which encompasses thermal energy from renewable sources. As a result, the Army needs to proceed in a way that makes sense for the Army in a good faith effort to satisfy Congressional, Administration, and Pentagon mandates and directives. The expectation is that the Army will meet the stricter definitions of EPAct on its way to meeting the much higher renewable goals of the NDAA. 


\section{Analysis of Renewables at Fort Hood}

This analysis is follow-on from the 2005 DoD Renewables Assessment. Its goal is to revisit the full suite of renewable alternatives at Fort Hood, updating the analyses to reflect changes in economics, incentives, local knowledge about the renewable resources, and other factors. This study contrasts with the DoD assessment in that the latter focused on "utility scale" renewable generating projects from wind and geothermal resources and solar for on-site use. The current study encompasses the full range of renewable energy options listed in EPAct, primarily focused on uses on site. The most significant additions are for biomass and waste-energy resources and for use of geothermal heat pumps.

\section{Approach for Identifying, Analyzing, and Implementing Renewable Energy Projects}

Renewable energy resources are unlike conventional resources because the "fuel" is essentially free. However harnessing this free resource requires substantial investment in resource exploration, characterization, and collection; project development; and ongoing maintenance and operation. A renewable resource is like purchasing a new car with a lifetime of fuel as part of the purchase agreement. First costs are much higher, but total cost may be (should be) lower over the long run.

Economic development of renewable energy depends upon:

$\checkmark$ Access to a renewable resource,

$\checkmark$ Development resources, and

$\checkmark$ Financing that is economically attractive and allowed by federal and DoD regulations.

Each of these is critically important.

Obviously, a renewable resource has to be available and accessible to be developed. The best resources are those with the greatest potential for displacing conventional fuels or power supplies. Development cost, however, is the great equalizer, and an excellent resource that is located many miles away may be inferior to a lesser resource nearby. For example, an excellent wind resource far from an adequate transmission line may be less attractive than an inferior resource adjacent to a transmission line. Similarly, waste resources that could be used in a central plant may not be economic, even if they are "free," if the availability, transportation, handling, and storage costs are greater than continued use of conventional heating fuels.

Development costs are relatively comparable for similar size projects. This is why the quality of the resource is so important—namely for the same investment, you get more out of a high quality resource than a lower quality one. But, development costs also include access to transmission to ship power to users, or alternatively, access to a retail customer. This is a critical difference because power shipped over transmission lines has to compete against the prevailing wholesale price for power from conventional resources. Typically, renewables are not competitive in these markets unless a buyer specifically demands renewable power. On the other hand, if the power can be used on site to displace power purchased from the local utility, it competes against that customer's retail power price or utility rate. Because retail power prices include costs for transmission, distribution, and administrative costs, they are higher than wholesale power prices and make renewable projects more attractive economically.

It is important that economic analyses of renewable energy opportunities use realistic data on avoided energy costs, project costs, and available incentive funds, if any. A common analytic mistake is the use of average cost per kWh-the so-called "blended" rate. Using the blended rate will lead to inaccurate 
results when the renewable resource is intermittent (like wind and solar) because intermittent resources cannot be guaranteed to reduce peak demand. Even non-intermittent resources may not result in reduced peak demand because of periodic maintenance shutdowns and unscheduled outages. The economic analyses in this report use only the energy component of the power bill to evaluate intermittent resources. This is admittedly conservative.

Additionally, the installation's utility may impose a stand-by or other fee in the face of a major on-site generation project that needs to be reflected in the projects avoided cost calculation. The analyses conducted here make no assumptions regarding standby charges for other types of renewable generation because those are typically assessed on a project-by-project basis.

\section{Importance of Financing Mechanisms for Project Feasibility}

Financing is a critical determinant of development costs because the high first costs are sensitive to financial factors such as incentive payments, tax breaks, and interest rates. Incentive payments and tax breaks reduce first costs, lowering both the overall project cost and interest costs. Because financing is so critical, project economics (payback rates, life-cycle costs, etc.) constitute the best initial screen for project potential. That screen needs to reflect various financing alternatives, which in turn, helps energy managers decide on the best project development approach.

The 2005 DoD Renewable Assessment focused on wind, solar and geothermal power production under the assumption these were the lowest cost and most available on DoD lands. The study was also focused on "utility-scale" projects on the premise that if a good renewable resource exists at a site, it should be developed to its maximum potential. Utility-scale projects far exceed any realistic expectation for appropriated funding, so the assessment focused on commercial (third party) development of projects. Besides funding limitations, there are other reasons that these large projects should be implemented by third-party investors - under current DoD philosophy, resource development is not a core DoD mission and should be left to the private sector. In addition, private developers value renewable energy credits (RECs) more highly than the Army does. As a result, letting the developers retain the RECs will reduce the cost of energy to the installation if the developer is selling power from the project to the site.

Private sector developers have to compete in wholesale power markets. As a result, one economic criterion for the DoD study was that projects be competitive with current and projected wholesale power prices. Utility-scale wind, geothermal, biomass, landfill gas and MSW projects, under the right conditions, can be (and are currently) competitive.

The DoD study found that "utility-scale" potential for geothermal and wind power production on military installations is rare. It did, however, identify good potential for projects to serve on-site needs, although these still require more site-specific data collection and analysis to develop projects. A similar lack of data forced the DoD assessment to ignore potential for biomass and waste energy projects. At the same time, the study revealed factors that make assessing the potential for biomass and waste energy more complicated than simply correlating resources on a map with the location of DoD facilities. Specifically, a significant fraction of the costs of biomass and waste energy projects is in fuel collection and delivery. If that infrastructure doesn't exist, economic projects are unlikely. For example, crop waste is often cited as a potential renewable fuel. However, farmers typically rotate crops so sources will vary over time and across the potential "fuel shed." In addition, farming is notoriously sensitive to the weather, making the quantity of waste highly variable. Without a reliable source of renewable fuel, biomass is neither reliable nor economic. As a result, assessment of biomass and waste energy projects needs to be based on an industry and market analysis rather than simplistic resource surveys. This is 
also the case for waste materials that can be used for "free" fuel. Agricultural wastes such as poultry litter are a nuisance currently and available for "free." However, the cost of transportation fuel has become an issue and plant operators are now being charged hauling fees. Higher fees are likely if demand for these materials increases with development of more projects that rely upon them.

\section{The Political and Economic Environment for Renewables at Fort Hood \\ Fort Hood Energy Characterization}

Fort Hood consumed 450,854 MWh in FY 2007 (including reimbursable loads). Hood is a summerpeaking facility, with its peak consumption in September (52,351 MWh), and a peak demand in July of 106,793 KVA. The total electricity bill in FY 2007 was $\$ 38.4 \mathrm{M}$, for an average or blended rate of $8.51 \mathrm{\$} / \mathrm{kWh}$. This breaks down into an energy charge of $\sim 7.9 \$ / \mathrm{kWh}$, and a demand charge of about $\$ 5.3 / \mathrm{kW}$. The demand charge includes transmission and distribution charges, and transition and system benefit funds, all on a per kW basis. Fort Hood reported in its most recent Army energy management report (2007) that less than 1\% of its kilowatt-hours are produced by self-generated renewable energy sources such as active daylighting, solar parking lot lights, and solar pedestrian crosswalk warning lights.

\section{State Incentives for Renewable Project Development}

Texas has partially deregulated its retail power market—parts of the state and some utilities are currently exempt. In the deregulated portion of the state, there are few direct incentives for the development of renewable generation projects. Utilities that remain regulated offer direct incentives, as do some of the municipal and cooperative utilities. Indirect incentives in the form of tax exemptions and other offsets are available for some renewable projects. Property and franchise tax (the Texas equivalent of a state corporate tax) exemptions are available for other renewable projects. Entities have to apply for tax exemption and be qualified by the state. A franchise tax exemption is available for solar and wind generation. Biomass gasification, solar, and wind generation projects are exempt from property tax. Biomass combustion technologies are not exempt (DSIRE 2007b). These incentives are obviously available only to tax-paying entities, and are not directly available to Fort Hood. They may, however, benefit a Fort Hood project supported by a third-party investor.

As part of the deregulation process, the state also adopted a renewable portfolio standard (RPS) that requires retail power suppliers to supply a fraction of their power from renewable resources. This RPS is primarily implemented through a Renewable Energy Certificate (REC) market operated by the Electric Reliability Council of Texas (ERCOT). The RPS has been a powerful catalyst for renewable energy development in the state, with Texas leading the nation in wind farm development.

\section{Federal Incentives for Renewable Project Development}

Federal incentives for renewable energy include investment tax credits for corporations, significantly accelerated depreciation of equipment, and production tax credits. A 30\% tax credit is available for photovoltaic (PV) projects, and 10\% for geothermal electricity projects. The credits may be taken on equipment placed in service prior to December 2008. There are no incentive limits for solar and geothermal electric projects. Wind is not eligible for the business energy tax credit. The tax basis for depreciation must be reduced by the amount of any federal subsidy used in the financing of the eligible equipment (26 USC § 48).

Depreciation for most renewable energy equipment qualifies for significantly accelerated depreciation. For solar, wind and geothermal, the modified acceleration cost recovery system (MACRS) provides for 5 -year recovery of the cost of equipment. The 5-year recovery period doesn't apply to biomass or waste energy equipment (26 USC § 168, 2005). 
The renewable energy production tax credit (PTC), originally established in 1992, provides a tax credit for each kilowatt-hour of electricity produced. The PTC is $2.0 \$ / \mathrm{kWh}$ for wind, geothermal, and closedloop biomass. The PTC is $1.0 / \mathrm{kWh}$ for electricity produced from open-loop biomass and municipal solid waste resources. The credit can be taken for 10 years from the time the equipment is placed in service (H.R. 6111, 2006).

Solar, has historically been eligible for a $10 \%$ investment tax credit. It was also briefly eligible for the PTC starting with the 2004 renewal and lasting through 2005. Starting in 2006, the investment tax credit for solar increased to 30\% of eligible system costs (with a \$2000 cap for residential systems) (H.R. 6111, 2006). The higher solar investment tax credit expires after December 31, 2008, although the $10 \%$ credit will remain in place.

All of the analysis conducted in this report assumes that the PTC and other tax credits will be available when the equipment is placed in service. 


\section{Results and Recommendations}

A summary of analysis results is presented in Table 3, broken down into economically viable (green), less favorable (amber), or nonviable (red) projects. The underlying analyses and recommendations for each of these technologies and potential projects are provided in the following subsections.

Table 3: Summary of Fort Hood Renewable Energy Opportunities

Renewable Assessment Results for Fort Hood

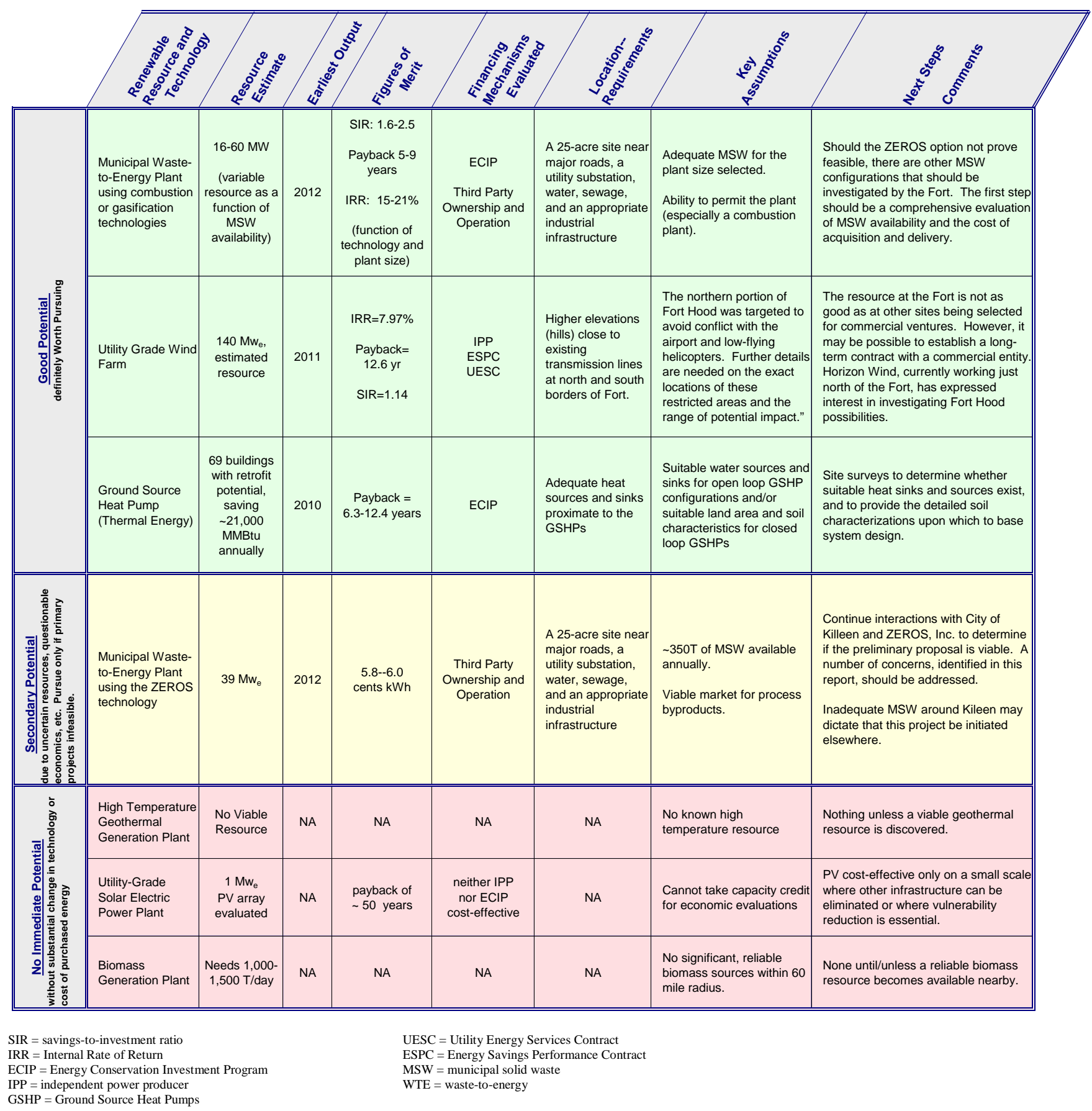




\section{Waste-to-Energy Recommendations}

Electricity generation using municipal solid waste (MSW) is an established power generation technology. Growth has been limited because of public and environmental concerns about combustion byproducts. New technologies that gasify materials thermally or with a plasma arc rather than combustion are available, but they are fairly new to the market and somewhat more expensive. Generation using wastes, including urban waste wood, appears to be feasible across a range of potential project sizes and energy conversion technologies at Fort Hood. The economics of these prospective projects are highly sensitive to plant size, and the availability and price of delivered MSW. There are multiple options to consider when using MSW for energy production: site waste only, site waste with city transfer station waste (TS), site waste with landfill waste (LF), and all waste. In addition, each of these options can use combustion, gasification, or plasma melting. The combinations that are cost effective or close to cost effective are presented in Tables 4 (combustion) and 5 (gasification and plasma technologies).

Table 4: MSW Waste-to-Energy Results for Combustion Technologies

\begin{tabular}{|c|c|c|c|c|}
\hline Waste Source(s) & Hood & $\begin{array}{c}\text { Hood, } \\
\text { Killeen Transfer Station, } \\
\text { \& Copperas Cove } \\
\text { Transfer Station }\end{array}$ & $\begin{array}{l}\text { Hood and } \\
\text { Temple } \\
\text { Landfills }\end{array}$ & All \\
\hline Technology & Combustion & Combustion & Combustion & Combustion \\
\hline Plant Size & $2.75 \mathrm{MW}$ & $16.1 \mathrm{MW}$ & $31.8 \mathrm{MW}$ & $45.1 \mathrm{MW}$ \\
\hline Feedstock Amount & $\begin{array}{l}25,000 \\
\text { tons/yr }\end{array}$ & 145,898 tons/yr & $\begin{array}{c}288,882 \\
\text { tons/yr }\end{array}$ & $\begin{array}{l}409,780 \\
\text { tons/yr }\end{array}$ \\
\hline Total Plant Cost & $\$ 4860.9 / \mathrm{kW}$ & $\$ 3415.8 / \mathrm{kW}$ & $\$ 2979.6 / \mathrm{kW}$ & $\$ 2778.4 / \mathrm{kW}$ \\
\hline Capital Cost & $\$ 4553.5 / \mathrm{kW}$ & $\$ 3199.8 / \mathrm{kW}$ & $\$ 2791.2 / \mathrm{kW}$ & $\$ 2602.7 / \mathrm{kW}$ \\
\hline Sales Tax & $\$ 307.4 / \mathrm{kW}$ & $\$ 216.0 / \mathrm{kW}$ & $\$ 188.4 / \mathrm{kW}$ & $\$ 175.7 / \mathrm{kW}$ \\
\hline Fixed O\&M Cost & $\$ 234.6 / \mathrm{kW}$ & $\$ 102.9 / \mathrm{kW}$ & $\$ 89.38 / \mathrm{kW}$ & $\$ 85.32 / \mathrm{kW}$ \\
\hline Variable O\&M Cost & $-3.5 \$ / k W h$ & $-3.6 \$ / k W h$ & $0.56 \$ / k W h$ & $-0.70 \$ / \mathrm{kWh}$ \\
\hline Feedstock Cost & $\$ 38.46 /$ ton & $\$ 40 /$ ton & $\$ 5.52 /$ ton & $\$ 15.86 /$ ton \\
\hline SIR & 1.0 & 2.5 & 1.6 & 2.2 \\
\hline Simple Payback & 13.4 years & 5.6 years & 8.5 years & 6.3 years \\
\hline $\begin{array}{l}\text { Internal Rate of Return (IRR), No } \\
\text { Financing }\end{array}$ & $9.05 \%$ & $20.55 \%$ & $15.16 \%$ & $19.47 \%$ \\
\hline
\end{tabular}

These scenarios show that a number of options are available to Fort Hood. If looking at only the noncombustion options (recommended because of reduced emissions and ease of permitting), using all waste in the area is the economic choice. However, the greater energy production and more attractive economics must be weighed against the increased on-post waste delivery traffic and the need to store a larger quantity of waste. So, smaller projects should be considered as well. Only Fort Hood can make the decision on whether to take on additional management challenges to gain additional energy output. 
Table 5: MSW Waste-to-Energy Results for Gasification and Plasma Melting Technologies

\begin{tabular}{|c|c|c|c|c|}
\hline Waste Source(s) & $\begin{array}{c}\text { Hood, Killeen Transfer } \\
\text { Station, \& Copperas Cove } \\
\text { Transfer Station }\end{array}$ & $\begin{array}{l}\text { Hood \& } \\
\text { Temple } \\
\text { Landfills }\end{array}$ & All & $\begin{array}{c}\text { Hood, Killeen Transfer } \\
\text { Station, \& Copperas Cove } \\
\text { Transfer Station }\end{array}$ \\
\hline Technology & Gasification & Gasification & Gasification & Plasma Melting \\
\hline Plant Size & $21.2 \mathrm{MW}$ & $42.1 \mathrm{MW}$ & $59.7 \mathrm{MW}$ & $10.9 \mathrm{MW}$ \\
\hline $\begin{array}{l}\text { Feedstock } \\
\text { Amount }\end{array}$ & 145,898 tons/yr & $\begin{array}{c}288,882 \\
\text { tons/yr }\end{array}$ & $\begin{array}{c}409,780 \\
\text { tons/yr }\end{array}$ & 145,898 tons/yr \\
\hline Total Plant Cost & $\$ 3492.5 / \mathrm{kW}$ & $\$ 3046.5 / \mathrm{kW}$ & $\$ 2840.8 / \mathrm{kW}$ & $\$ 6948.4 / \mathrm{kW}$ \\
\hline Capital Cost & $\$ 3271.7 / \mathrm{kW}$ & $\$ 2853.9 / \mathrm{kW}$ & $\$ 2661.2 / \mathrm{kW}$ & $\$ 6509.0 / \mathrm{kW}$ \\
\hline Sales Tax & $\$ 220.8 / \mathrm{kW}$ & $\$ 192.6 / \mathrm{kW}$ & $\$ 179.6$ & $\$ 439.4 / \mathrm{kW}$ \\
\hline Fixed O\&M Cost & $\$ 171.3 / \mathrm{kW}$ & $\$ 106.4 / \mathrm{kW}$ & $\$ 84.03 / \mathrm{kW}$ & $\$ 276.7 / \mathrm{kW}$ \\
\hline $\begin{array}{l}\text { Variable O\&M } \\
\text { Cost }\end{array}$ & $-3.1 \$ / k W h$ & 0.12 \&/kWh & $-0.83 \$ / k W h$ & $-6.6 \$ / k W h$ \\
\hline $\begin{array}{l}\text { Feedstock } \\
\text { Cost }\end{array}$ & $\$ 40 /$ ton & $\$ 5.52 /$ ton & $\$ 15.86 /$ ton & $\$ 40 /$ ton \\
\hline SIR & 1.8 & 1.6 & 2.2 & 1.0 \\
\hline Simple Payback & 7.8 years & 8.7 years & 6.3 years & 13.9 years \\
\hline $\begin{array}{l}\text { Internal Rate of } \\
\text { Return (IRR), } \\
\text { No Financing }\end{array}$ & $16.16 \%$ & $15.22 \%$ & $19.82 \%$ & $8.54 \%$ \\
\hline
\end{tabular}

\section{Wind Energy Findings and Recommendations}

There appears to be plenty of available land on Fort Hood with the potential for a low to medium quality wind resource, with the best resources typically located at higher elevations. There are many hills within the boundaries of Fort Hood that could have potentially good wind. This analysis is based upon a 140-MW wind project in the southern part of the Fort. However, there may be siting constraints because of helicopter operations and the airport, which may restrict development to the northern region of the Fort. If that is the case, then the viable project is probably limited to $100 \mathrm{MW}$ or less because of available capacity on the existing 69-kV transmission line on the northern perimeter. The larger project could be possible if the economics allow further transmission capacity development in the north.

Wind generation is almost economic at Fort Hood under three financing scenarios: a power purchase from a third party independent power producer (IPP), appropriated funds, and development in partnership with a utility. Each of these financing options has different costs for borrowed funds and different tax incentives. The cost of on-site wind production at the tested scale (100 MW or larger) is close to the cost of commercial power currently provided by Constellation Energy, and wind generation is likely to become more competitive as commercial electricity costs increase in the future. IPP projects require at least a $10 \%$ internal rate of return (IRR) after tax to attract private investment (15\% is more representative). At a commercial energy cost of $7.9 \$ / \mathrm{kWh}$, a $140-\mathrm{MW}$ project at Fort Hood would provide a $7.97 \%$ IRR, which is low, but close to being financeable. At $9.5 \$ / \mathrm{kWh}$, the project yields a 10.22\% IRR. ECIP projects require an SIR of 1.25, while UESC requires payback by life of renewable and SIR > 1.0. Competing against the $7.9 \$ / \mathrm{kWh}$, the SIR is 1.14 and the payback is 12.6 years. 
The wind resource at Fort Hood is not likely to be as good as at some other regional sites. However, Fort Hood may have some institutional characteristics that could make it attractive to a wind developer. Horizon Wind, a wind energy developer working in Texas, was consulted regarding the potential for a project on or near Fort Hood. Horizon has investigated the feasibility of a wind project in the area north of Gatesville, a community just north of Fort Hood. The company has expressed interest in holding discussions with Fort Hood if the Fort is (1) interested in being a long-term buyer for energy generated just off post, or (2) for developing a wind project on post.

It makes sense to pursue wind generation projects on post at this time because the current cost of commercial power is only slightly lower than the wind generation projection. One important characteristic of wind power is that its cost is not dependent upon the cost of fossil fuels. Because the cost of fossil-generated energy is expected to increase on a continuing basis, it may be possible to negotiate a fixed-price long-term (20-year) supply contract now that will save considerable money over the term of the contract. Fort Hood may also want to consider the possibility of buying energy off post through a negotiated renewable energy tariff with Constellation Energy, or a partnership with a wind developer for a project located either on post or off post.

\section{Ground Source Heat Pump Findings and Recommendations}

We evaluated the potential for retrofit of HVAC systems in all buildings with ground source heat pumps, looking at both open-loop systems and closed-loop systems. The retrofit was not deemed cost effective for most buildings on post, including all buildings with air-source heat pumps and all buildings without existing ductwork. Additionally, fan coil units, window air conditioning (AC) units, and related equipment cannot economically be replaced with GSHPs, regardless of the building type, size, or vintage. Chillers and boilers with air handling units were found to be the most cost-effective technology combination. Cost-effective opportunities were identified only for appropriated (ECIP) funds.

Alternative financing never resulted in a cost-effective project.

Tables 6 and 7 show the cost-effective GSHP options and their respective simple paybacks. Simple paybacks are noted in brackets. Only two buildings were found to be cost effective for open-loop GSHP retrofits (Table 6) at Fort Hood_-an administrative building (Building 1001) and the PX (Building 50004).

Table 6: Cost-Effective Open-Loop GSHPs with Appropriated Funding

\begin{tabular}{||c||c||}
\hline \hline HEATING/COOLING TECHNOLOGY & \multicolumn{1}{c||}{ Chiller with Air Handling Unit } \\
\hline \hline $\begin{array}{c}\text { Gas Boiler with } \\
\text { Air Handling Unit }\end{array}$ & Admin; 316,996sf; 1989 - high efficiency [7.1 yrs] \\
& PX; 307,330sf; 1977 - high efficiency [6.3 yrs] \\
\hline
\end{tabular}


Table 7: Cost-Effective Closed-Loop GSHPs with Appropriated Funding

\begin{tabular}{||c||c|c||}
\hline & $\begin{array}{c}\text { Chilled Water with } \\
\text { Air Handling Unit }\end{array}$ & Package DX Units \\
\hline \hline $\begin{array}{c}\text { Hot Water with } \\
\text { Air Handling Unit }\end{array}$ & $\begin{array}{l}\text { Admin; 3,919sf; 1999 - horizontal } \\
\text { high efficiency [*] }\end{array}$ & \\
\hline Electric Furnace & & $\begin{array}{l}\text { Range Facilities; 2,107sf; 1995 - } \\
\text { horizontal high efficiency [12.4 yrs] }\end{array}$ \\
\hline
\end{tabular}

*All retrofits from central heating and cooling are cost effective only if the CEP loop is abandoned.

With closed-loop GSHPs, only buildings using electric heating and cooling, and projects gaining savings from abandoned distribution lines were found to be cost effective. These buildings are listed in Table 8:

Table 8: Fort Hood Buildings with the Potential for Cost-Effective GSHP Retrofit

\begin{tabular}{|c|c|c|c|c|c|c|c|c|}
\hline 91230 & 56004 & 56152 & 56184 & 56206 & 56231 & 56250 & 56275 & 56285 \\
\hline 91231 & 56006 & 56161 & 56187 & 56212 & 56233 & 56251 & 56276 & 56286 \\
\hline 91232 & 56007 & 56173 & 56190 & 56214 & 56235 & 56255 & 56277 & 56290 \\
\hline 91233 & 56117 & 56174 & 56192 & 56215 & 56237 & 56257 & 56278 & \\
\hline 91234 & 56118 & 56177 & 56197 & 56223 & 56240 & 56266 & 56279 & \\
\hline 91235 & 56120 & 56179 & 56200 & 56225 & 56244 & 56267 & 56281 & \\
\hline 91236 & 56126 & 56180 & 56202 & 56227 & 56245 & 56270 & 56282 & \\
\hline 91237 & 56143 & 56181 & 56203 & 56230 & 56248 & 56271 & 56284 & \\
\hline
\end{tabular}

If retrofits are realized in all 69 of these buildings, about 20,924 MMBtus could be saved per year. The maximum electric load of this equipment, based on rated size, would be about 6.7 MW.

\section{Geothermal Power Plant Findings and Recommendations}

According to available data, Fort Hood lacks naturally occurring hot water/steam fields and elevated temperatures at economic depths (less than $3000 \mathrm{~m}$ ). Fort Hood also lacks sufficient heat flow rates for geothermal energy production. At this time, Fort Hood is not a candidate for utility-scale geothermal energy production.

\section{Solar Energy Findings and Recommendations}

Grid-connected (utility scale or smaller) solar photovoltaic plants are not close to being economic at Fort Hood because solar cannot compete with the low cost of commercial power from Constellation Energy. In making this judgment, the economic hurdle is the $7.9 \mathrm{\$} / \mathrm{kWh}$ energy component of the average electricity cost.

A representative fixed axis, grid-connected PV project has a 0.3 SIR and a 55.4-year simple payback. To get a positive net-present-value, the system would have to displace power that costs $41 \Phi / \mathrm{kWh}$. Even with carbon taxes and selling renewable energy credits it would be extremely difficult to develop a project like this. A representative axis-tracking PV system does only slightly better (as a result of its better capacity factor) at 49.9 year simple payback producing $38 \$ / \mathrm{kWh}$ power.

\section{Biomass Recommendations}

Generation of electricity from animal waste, forest thinnings, logging slash, mill residue, and wastewater sludge is not worth pursuing because of inadequate resource availability. Generation using crop residues, dedicated biomass crops, and industrial waste is not economic. Landfill gas is not viable 
because the projected output would be less than $1 \mathrm{MW}_{\mathrm{e}}$, and considerably less if the landfill were closed in favor of a waste-to-energy plant. The bottom line is that there are no viable biomass generation projects for Fort Hood at this time. This could change as interest in growing dedicated energy crops increases. Interest in these "closed-loop" biomass projects is growing as the biomass energy industry matures. 


\section{APPENDIX A}

\section{Business Case Analysis Approach}


Renewable Energy Opportunities at Fort Hood, Texas Pacific Northwest National Laboratory, June 2008 


\section{Appendix A: Business Case Analysis Approach}

\section{Overall Basis for Project Economic Feasibility}

The renewable projects considered in this analysis need to compare favorably against the commercial price of electricity currently purchased by the Fort to be economically feasible. Fort Hood purchases its electricity from Constellation Energy at a total cost of $8.5 \$ / \mathrm{kWh}$. The energy component is $7.9 \$ / \mathrm{kWh}$, with delivery and capacity charges costing, on average, $0.6 \$ / \mathrm{kWh}$. Wind and solar projects produce power intermittently, therefore they need to meet the energy-only price of $7.9 \$$ to be economically feasible. Base-loaded projects that eliminate the need for backup capacity, such as biomass and geothermal can be compared against the $8.5 \$$ hurdle.

All but one of the analyses was conducted using the Financial Analysis Tool for Electric Energy Projects financial analysis model (FATE2-P), described later in this appendix. The analysis for ground source heat pumps was conducted using the Federal Energy Decision Screen (FEDS) model, also described in this appendix.

\section{Analytic Approaches}

In assessing the economic feasibility of renewable energy projects at Fort Hood, PNNL generally evaluated two business case alternatives, (1) investment by an independent power producer (IPP), and (2) Energy Conservation Investment Project (ECIP) funding. These two funding sources have the best returns on federal investments among the available alternatives. Two other alternatives were examined when conditions were also favorable, (3) the utility energy services contract (UESC), and (4) the energy saving performance contract (ESPC).

Under an IPP scenario, an independent power producer will generally fund, construct, and operate a renewable energy facility, selling power into the competitive marketplace and/or directly to the site that hosts the energy project. This scenario is generally economic when the third-party investor can take advantage of substantial federal and state incentives. The incentives depend on the type of renewable energy and may include production tax credits, investment tax credits, substantially accelerated tax depreciation of assets, reductions in sales taxes, and exemption from property tax.

The Energy Conservation Investment Program is one standard DoD approach for making energy efficiency and renewable energy investments using federally appropriated funding. ECIP investment awards are made based upon savings to investment ratio (SIR) and simple payback (SPB) criteria. ECIP funding is limited, and is awarded on a competitive basis within the Army-only the most economic projects can be assured funding. The approach used in the analyses follows the Federal life cycle cost methodology (LCC) and Procedures in 10 CFR, Part 436, Subpart A. The LCC calculations are based on the Federal Energy Management Program (FEMP) discount rates and energy price escalation rates updated on April 1, 2007.

UESC and ESPC are very similar approaches, where a third party invests in an energy project on the federal facility in return for a share of the energy savings that result. The major difference is that under UESC, the third party is a utility - generally the utility providing energy to the federal facility. Under ESPC, the investment party is a non-utility, generally an engineering firm that specializes in energy projects. Under UESC and ESPC, the third party must be repaid out of each year's operational dollars, and the investment must be repaid within the lifetime of the asset. Generally, UESC is more viable than ESPC because utilities can obtain capital less expensively than can the ESPC contractor. But not all 
utilities fund UESC projects and the types of projects funded may be limited, opening the door for ESPC. The UESC/ESPC cannot generally capture depreciation or tax incentives that would be afforded an independent power producer.

\section{Independent Power Producer Assumptions}

In addition to capital and operating costs, project feasibility for the independent power producer is dependent on federal and state tax incentives, interest rates, inflation rates, and required rates of return discussed in the following sections.

\section{Federal Incentives for Renewable Energy}

Federal incentives for renewable energy include investment tax credits for corporations, significantly accelerated depreciation of equipment and production tax credits. Combining the incentives with attractive market prices can, in certain cases, lead to feasible renewable energy projects.

\section{$\underline{\text { Tax Credits }}$}

A 30\% business energy tax credit is available for photovoltaic projects. Geothermal and biomass electricity generation projects qualify for a $10 \%$ investment tax credit. The credits may be taken on equipment placed in service prior to December 2008 (JCT 2007). There are no incentive limits for solar and geothermal electric. Wind is NOT eligible for the business energy tax credit. The tax basis for depreciation must be reduced by the amount of any Federal subsidy used in the financing of the eligible equipment (26 USC $\S 48$ ). The basis of the facility is eligible for $50 \%$ of the total energy tax credit taken (JCT 2007).

\section{Depreciation}

Most renewable energy equipment qualifies for significantly accelerated depreciation using the modified accelerated cost recovery system (MACRS). According to 168(e) (3) (B) (vi) most renewable energy production facilities would qualify for 5 year accelerated depreciation (US Treasury 2007).

Table A-1 provides the depreciation rates used in the model for 5-year property. They reflect the use of the half-year convention. The basis is reduced by $50 \%$ of any energy investment tax taken (JCT 2007).

Table A.1: MACRS Depreciation Rates for Renewable Energy Projects

\begin{tabular}{|c|c|c|c|c|c||}
\hline Year 1 & Year 2 & Year 3 & Year 4 & Year 5 & Year 6 \\
\hline $60 \%$ & $16 \%$ & $9.6 \%$ & $5.76 \%$ & $5.76 \%$ & $2.88 \%$ \\
\hline
\end{tabular}

\section{Production Tax Credits}

The renewable energy production tax credit (PTC) provides a per-kWh-produced tax credit for electricity generated. The PTC is $2.0 \$ / \mathrm{kWh}$ in 2007 for wind, geothermal, and closed-loop biomass and can be taken for 10 years. The PTC is $1.0 / \mathrm{kWh}$ for electricity produced from open-loop biomass, municipal solid waste resources and can be taken for 5 years. Solar electricity generation has been excluded for equipment placed in service after December 2005 (H.R. 6111, 2006). The PTC has been allowed to lapse and then been renewed several times (DSIRE 2007a). All of the analysis assumes it will be available when the equipment is placed in service. 


\section{Texas-Specific Incentives and Taxes}

Texas provides a franchise tax exemption for solar and wind generation. Entities have to apply for the exemption and be qualified by the state. The franchise tax is the Texas equivalent of a state corporate tax. Biomass gasification as well as solar and wind are exempt from the property tax. Biomass combustion technologies are not exempt (DSIRE 2007b).

A franchise tax of $1 \%$ was used as the franchise tax rate on taxable margin. Taxable margin approximates net operating revenue for biomass projects. We approximated the Texas franchise tax by applying 1\% to the revenues minus the costs of goods sold (State of Texas (a) 2008).

The property tax rate for Fort Hood was conservatively assumed to be $0.5 \%$, somewhat higher than the 2006 property tax rate of $0.411 \%$. The rate is applied to the installed value of equipment but not the land value. The land value is assumed to be exempt from property tax because it is Federal land (State of Texas (b) 2008).

The Bell county sales tax of $6.75 \%$ was assumed as the sales tax rate for installed capital on Fort Hood (State of Texas (c) 2008).

\section{Other Independent Power Producer Assumptions}

The minimum after-tax internal rate of return used in the analysis of IPP opportunities was $10 \%$. The typical after-tax rate of return for most third-party developers is closer to 15\%, but there appears to be a subset of renewable energy developers willing to accept a lower return. Both costs and prices were assumed to escalate with an inflation rate of $1.9 \%$. It should be noted that third-party investors would probably need to negotiate backup power options with both the Fort and Constellation Energy to assure that Fort Hood doesn't face substantial emergency power costs for any unplanned outages.

\section{Energy Conservation Investment Projects}

The assumptions for ECIP are driven by the Federal Energy Management Program. Table A-2 lays out the discount rates underlying the model as of April 2007. The Real and nominal rates for DOE/FEMP imply a $1.9 \%$ inflation rate. New rates were obtained from Marlin Addison (2007).

Table A.2: Discount Rate Assumptions in the ECIP model

\begin{tabular}{|r|c|c|c|c|c|c|}
\hline Discount Rate & DOE FEMP & OMB 3-year & OMB 5-year & OMB 7-year & OMB 10-year & OMB 30-year \\
\hline real & $3.0 \%$ & $2.5 \%$ & $2.6 \%$ & $2.7 \%$ & $2.8 \%$ & $3.0 \%$ \\
\hline nominal & $5.0 \%$ & $4.4 \%$ & $4.5 \%$ & $4.7 \%$ & $4.8 \%$ & $5.0 \%$ \\
\hline
\end{tabular}

\section{FATE2-P Model Description}

The FATE2-P (Financial Analysis Tool for Electric Energy Projects) financial analysis model was used to evaluate the feasibility of renewable energy projects at Fort Hood. The spreadsheet model was developed by Princeton Economic Research, Inc. and the National Renewable Energy Laboratory for the U.S. Department of Energy. FATE2-P can be used to develop pro forma financial statements for a utility using a revenue requirements approach or an independent power producer using the discounted rate of return approach. Both approaches are diagrammed in Figure A-1. Other models produce very similar results given the same inputs. The revenue requirements approach follows a cost-based utility revenue requirements analysis, and the independent power producer approach uses a market-based discounted cash flow return. The FATE2-P model has been updated by PNNL to include the MILCON 
Energy Conservation Investment Program Module in addition to the rate of return methodology. The model has been used to model improved technology designs, resource variability, and favorable tax treatment on renewable energy products. The advantage this model over other models is that it is already suited for handling all of the renewable energy technologies in this study through one model, thus providing results on a comparable basis across all technologies.
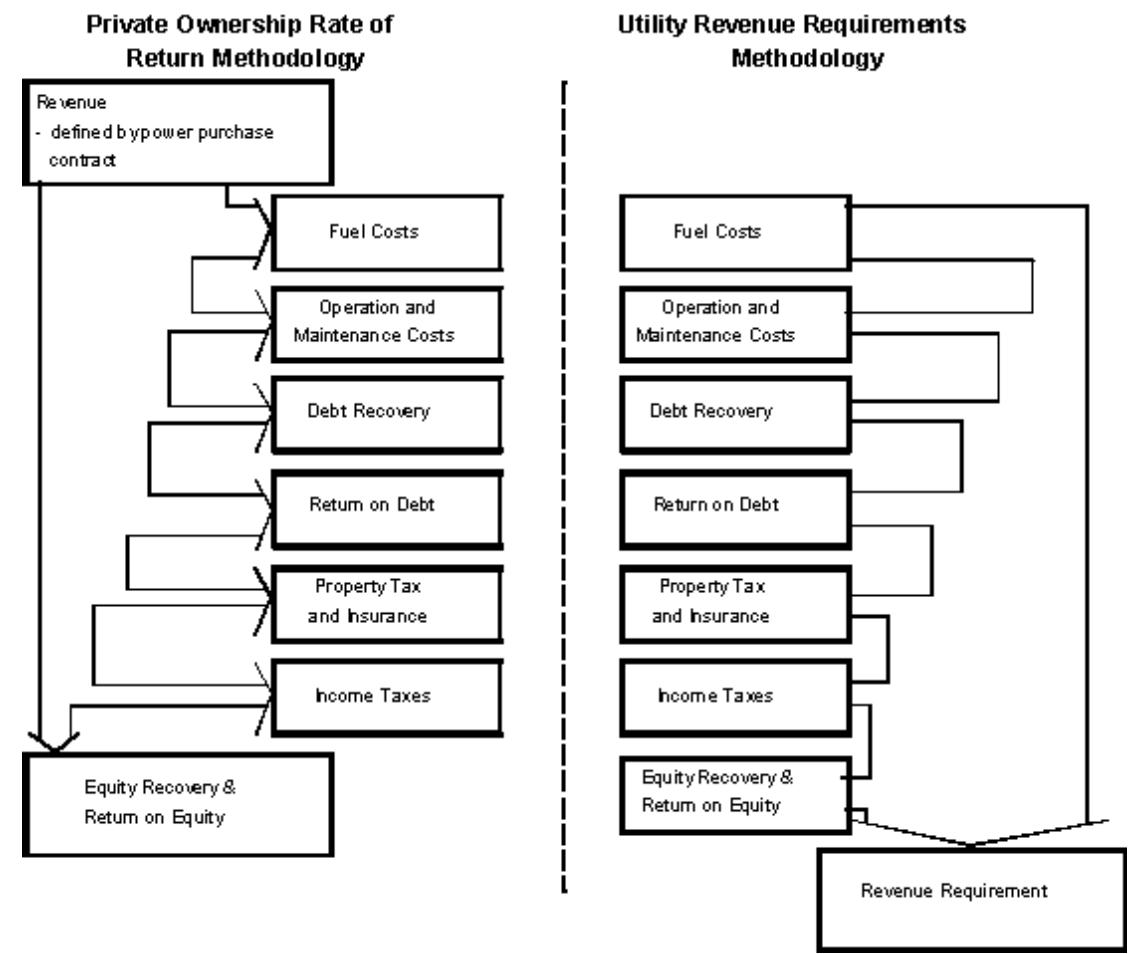

Figure A.1: FATE2-P Methodology

\section{Private Ownership Rate of Return Methodology}

The private ownership rate of return module (independent power producer) develops an annual after-tax cash flow based on the revenues defined in the power purchase contract and costs associated with constructing and operating the generation facility. The goal of this approach is to capture the relevant investment costs after-tax and compare them with the net cash flow from the investment after-tax over time. The model contains sections to capture the relevant costs of construction including the debt and equity capital accumulation to purchase the investment and the associated payback of debt and equity capital. In addition, the model has sections associated with revenue generation, cash flow, an income statement and associated statements to calculate tax liabilities to capture after-tax cash flow. The financing section includes several pertinent sections including sources and uses, construction and debt accumulation, reserve funds requirements, debt schedule, amortization of debt fees, and debt service coverage ratios.

$\checkmark$ The sources and uses of funds section shows the allocation of construction funds between components and sources of those funds. Uses of funds include construction cost, AFUDC (allowances for funds used during construction), underwriters' fees for both debt and equity.

$\checkmark$ The construction and debt accumulation statement is capable of handling a 6-year construction period starting at any date. Any construction draw schedule can be used for 1 to 6 years. An equal percentage draw schedule for each year of any given construction length is the default. 
$\checkmark$ The model contains major maintenance and debt-service reserve funds. Both types of accounts generate interest income that becomes a part of the income statement through a drawn-off interest calculation. The model doesn't currently calculate a working capital reserve account. Such an account would add interest costs to the cost statement in addition to the interest costs on the capital investment.

$\checkmark$ The debt schedule allows three types of financing: level payment, bullet, and customized. Level payment is pretty customary for projects that have adequate cash flow to satisfy debt coverage payments and are of short duration. Customized is required when certain years fall below the minimums set by the investment banking industry.

$\checkmark$ Cash flow statements can be constructed for up to 30 years of revenue generation plus the 6-year construction period.

$\checkmark$ The revenue module contains a variable capacity factor which must be filled in by the analyst to capture depletion of the geothermal fields, the capacity of wind or of the other renewables' capacities. This section also allows for secondary energy by-product credits (such as for steam if it has value), and up to 6 different types of subsidy payments if available. The model also accepts after-tax production credits, if available and includes any interest on reserves.

$\checkmark$ Cash expenses statements include standard operations and maintenance costs (both fixed and variable), general and administration (G\&A), insurance, and land fees. There is major maintenance expense along with a reserve fund dedicated to covering the major maintenance expense when it occurs. Up to two different fuel costs can be entered. There is also an entry for royalty fees associated with geothermal.

$\checkmark$ The earnings statement in this model calculates earnings and taxes based on a tax table. Operating income is generated by subtracting cash and operating expenses from revenue as described in the section above. Taxable income is determined by subtracting cash and non-cash expenses such as interest, depreciation, amortization of fees, IDC (interest during construction) and depletion allowances. Taxes paid and tax credits received are netted and after-tax book income is calculated. The net taxes paid become a part of the cash flow.

$\checkmark$ The model includes straight-line and MACRS (Modified Accelerated Cost Recovery System) depreciation approaches, with mid-quarter convention deprecation tables. Straight-line allows for the calculation of book basis value of assets and liabilities while MACRS allows for the taxable basis of the investment.

$\checkmark$ The model amortizes debt related fees over 15 years and equity organizational fees over 5 years. Equity tax advice is expensed in the first year, and equity broker fees are excluded.

$\checkmark$ The model calculates depletion allowances on geothermal projects. The model also depletes certain AFUDC when appropriate.

$\checkmark$ Income tax and other tax statements are prepared for federal and state taxes paid as well as tax credits earned. Tax calculations include excise taxes, federal, state and local taxes. Depreciation calculations used to capture after-tax cash flow can use either straight-line or MACRS. There is also section to incorporate local property taxes and special tax assessments.

$\checkmark$ Assumptions: The assumptions section is fairly extensive and covers construction costs, debt acquisition, equity acquisition, capacity factors, fixed and variable operations and maintenance $(\mathrm{O} \& M)$ inputs, financial factors such as interest rates, General and Administrative expenses, 
real escalation in O\&M charges, unfired fuel assumptions, byproduct credits, asset life, inflation rates, tax rates, property tax rates, insurance, Investment tax credits, AFUDC, local gross receipts tax, and special property tax assessments.

$\checkmark$ Total Plant Cost (Overnight) is divided into: Sales Tax; Rotor, Gearbox, Generator; Tower \& Civil Work; Controls, Transformer, Interconnect; Design/Engineering; Permitting/Environmental, Construction Labor \& Supervision; Contingency; Home Office Overhead; Real Escalation in Construction Cost; Misc. Depreciable Cost (last year of construction); Sales Tax on Miscellaneous Depreciable Cost; Land Cost; and Startup Cost.

\section{ECIP Module}

The FATE2-P model includes a life cycle cost module based on the Buildings Life Cycle Cost (BLCC) model (produced by the National Institute of Standards and Technology) and a MILCON Energy Conservation Investment Program (ECIP) Module, which in turn fills out Form 1391. The ECIP module currently reflects 2007 forecast discount and inflation rates. The ECIP module provides first year savings, simple payback, total discounted operational savings, savings-to-investment ratio (SIR), and adjusted internal rate of return.

\section{The Federal Energy Decision System (FEDS) Model}

FEDS is a building energy modeling software developed by Pacific Northwest National Laboratory to support the economic analysis of efficiency technologies at large, multi-building sites. Building characteristics are entered into the model using as much detail as possible, and the model uses the given information to make inferences for the remaining characteristics. Multiple sets of building data can be entered into the same model, so that an entire site can be represented at once. The optimization cycle uses data about the location of the site and the energy prices entered into the model to determine costeffective retrofits for each set of building data, and to calculate costs and savings. The suggested retrofits can range from lighting to building envelope to HVAC, covering all aspects of a building's energy use and considering interactive effects. In addition, the model can be adjusted to consider just one type of retrofit. In this renewable analysis conducted at Fort Hood, ground source heat pumps were the only technology analyzed.

\section{Business Case Analysis References}

Addison, M.S. and Associates, Tempe, AZ. 2007. "User-Friendly Building Life-Cycle Cost Analysis.” marlin.addison@doe2.com; provided June 2007.

DSIRE. 2007a. Federal Incentive for Renewables and Efficiency: Business Energy Tax Credit. http://www.dsireusa.org/library/includes/incentive2.cfm?Incentive_Code =US02F\&State=federal\&currentpageid=1\&ee=1\&re=1. Date visited 8/29/2007.

DSIRE 2007b. "Texas Incentives for Renewable Energy." http://www.dsireusa.org/library/includes/map2.cfm?CurrentPageID=1\&State=TX\&RE=1\&EE=1. Date visited 2/26/2008

H.R.6111. December 2006. “Tax Relief and Health Care Act of 2006” (Enrolled as Agreed to or Passed by Both House and Senate). Section 207

(JCT) Joint Committee on Taxation. October 4, 2007. “Description of the Chairman's Modification to the Provisions of the "Heartland, Habitat, Harvest and Horticulture Act of 2007" (JCX-96-07), 
Rushing, Amy S., Barbara C. Lippiatt. May 2007. “Energy Price Indices and Discount Factors for LifeCycle Cost Analysis - April 2007: Annual Supplement to NIST Handbook 135 and NISTIR 85-327322 (Rev. 5/07)”. NBS Special Publication 709

State of Texas. 2008a. "Comptrollers Online Tax Calculator.”

http://www.window.state.tx.us/taxinfo/taxforms/HB3Calc.pdf, Date accessed: 3/12/2008.

State of Texas. 2008b. “Texas Total County Property Tax Rates 1991 - 2006.” Texas Comptroller of Public Accounts. http://www.county.org/resources/countydata/products/TaxRates/general.html; Date accessed 3/12/2008.

State of Texas. 2008c. "Window on State Government: County Sales and Use taxes." http://www.window.state.tx.us/taxinfo/local/county.html . Date accessed: 3/12/2008.

United States Code Service. 26 USC § 48. Title 26. Internal Revenue Code. Subtitle A. Income Taxes. Chapter 1. Normal Taxes and Surtaxes. Subchapter A. Determination of Tax Liability. Part IV. Credits Against Tax. Subpart E. Rules for Computing Investment Credit

U.S. Department of Treasury. "2007 Instructions for Form 4562: Depreciation and Amortization (Including Information on Listed Property.” Internal Revenue Service.

United States Code Service. 26 USC § 168 (2006). Title 26. Internal Revenue Code. Subtitle A. Income Taxes. Chapter 1. Normal Taxes and Surtaxes. Subchapter B. Computation of Taxable Income. Part VI. Itemized Deductions for Individuals and Corporations

United States Code Service. 16 USC § 796 (2006). Title 16. Conservation. Chapter 12-Federal Regulation and Development of Power. Subchapter 1. Regulation of the Development of Water Power and Resources. Definitions. 
Pacific Northwest 


\section{APPENDIX B}

\section{Analysis of Biomass and Waste-to-Energy Opportunities}


Renewable Energy Opportunities at Fort Hood, Texas Pacific Northwest National Laboratory, June 2008 


\section{Appendix B: Analysis of Biomass and Waste-to-Energy Opportunities}

\section{Biomass and Waste-to-Energy Technology}

The term "biomass" refers to renewable fuels used for power production that include methane from landfills and wastewater treatment plants, agricultural waste, forest and wood processing waste, animal waste, industrial waste, dedicated biomass crops, and landfill gas. Waste-to-energy (WTE) is similar, but includes municipal solid waste (MSW) and construction and demolition (C\&D) waste as fuel sources. The Energy Policy Act of 1992 (EPAct) and some states and federal agencies (including DOE) differentiate these feedstocks into those that qualify as renewable sources for compliance purposes, and those that do not. While biomass and WTE projects may be very different as to their sources, fuel collection modes, and fuel cost profiles, in the end, energy production often relies on similar technologies.

The primary technologies for producing electricity rely upon steam turbines, gas turbines, or combined cycle turbine generators. Generators are energized by steam produced from direct combustion of raw material, or a synthetic gas (syngas) produced through anaerobic digestion or gasification. Direct combustion and anaerobic digestion technologies are mature and have been proven commercially. Gasification technologies are newer in the market, but are promising based on a number of successful installations. Anaerobic digestion is widely used but primarily for smaller applications in rural and municipal projects rather than large commercial installations.

The capital cost of biomass plants ranges from about $\$ 1500$ to $\$ 5000 / \mathrm{kW}$, depending upon scale and specific technologies used. Direct combustion technologies tend to be both larger and less capital intensive than those based on syngas. Digesters tend to be higher cost, primarily because of their smaller size. Operation and maintenance $(\mathrm{O} \& \mathrm{M})$ for digesters is also more, costing about $2.0 \$ / \mathrm{kWh}$, compared to about $1.0 \$ / \mathrm{kWh}$ for combustion plants. The advantage for digesters is the low cost of fuel, which is typically free, local waste (i.e., sewage sludge, manure). Even a "free" feedstock, such as crop wastes, does not guarantee a successful project, as collection, transportation, and storage costs can be, and often are, economically prohibitive. The economics of municipal solid waste (MSW) projects are typically more attractive than other biomass projects since fuel is often delivered free or even accompanied by payment in the form of a tipping fee. Most landfills are operated or franchised by a local government. Many of these derive operating revenues from fees that are added to the actual operating costs of the landfill. As a result, the tipping fee may be inflated over actual costs and therefore not an accurate representation of costs that can be avoided.

Combustion (direct-fired) systems burn biomass to produce steam in a boiler, turning a turbine connected to a generator. This method of producing electricity is quite inefficient, at about 20-30\%. In direct-fired systems, combustion products tend to form deposits on the heat transfer surfaces, increasing maintenance requirements and decreasing the lifetime of these surfaces, as a result of corrosion and erosion. Ash has to be collected and removed from the system. The variability of incoming feedstock in terms of its composition and moisture content can present problems in combustion systems, most notably with MSW and mixed feeds. Systems that use a more homogeneous feedstock benefit from more complete combustion, which increases efficiency and reduces combustion waste products and emissions. Various boiler designs try to address these issues.

Gasification is more efficient than combustion, but the technologies employed are not as mature or common in commercial operation. Gasification uses oxygen, steam, heat, and pressure to break down 
organic materials to produce syngas, which is primarily hydrogen and carbon monoxide. Syngas is cleaned to remove impurities, then used to generate electricity in a gas turbine or fuel cell, or used to produce transportation fuels or commercially valuable chemicals. The inorganic materials are discharged as inert solids that can often be used for another purpose. There are many types of gasification designs that use different amounts of oxygen and steam at different stages and temperatures, producing different amounts of waste heat, syngas, and solids.

One gasification process is just entering the commercial market now for use with MSW, but is worth noting because of its high potential and interest for use on military sites. The plasma melter uses plasma to heat the material being gasified, resulting in a much higher temperature and more complete reaction. This new technology produces only syngas from the organics, molten metal alloy from any metals, and an obsidian-like substance from the inorganics. No emissions are created during this process, and the solid waste can be sold and used for other purposes. Ash collected from syngas cleaning can be fed back into the plasma melter. Hazardous materials can also be gasified in this process, converting the toxic substances into the glass-like waste with no potential for leaching.

Digesters tend to be smaller systems and are typically used just for biomass. They are usually located at the biomass source, such as farms with significant amounts of animal manure and wastewater treatment facilities. Digesters break down biomass in warm, wet environments to produce methane, which can be captured as fuel for generating electricity. Aerobic digesters are common in poor countries for production of heating and cooking fuel in rural areas. Anaerobic digesters limit the amount of oxygen in the gasification process and therefore produce gas with a higher concentration of methane, which is better for power production. Because of the smaller size of digester systems, electricity is typically generated using fuel cells, microturbines, or reciprocating engines.

Methane is also produced through anaerobic digestion in landfills as the garbage underground breaks down. It is sometimes left in the ground, but the risk of fire has led most landfills to remove the methane and flare it in a controlled manner. The flare could be replaced with an electricity generation system if the economics are positive. The most economic opportunities for landfill methane capture and use are in cases where the landfill already has a collection system in place, is active or recently closed (methane production tapers off as landfills age), and has sufficient waste (typically at least 1 million tons) to generate a significant amount of methane. The landfill must be lined as well, to prevent water intrusion into the landfill that stifles digestion of the waste and methane production and to prevent the methane from migrating into the surrounding soil. New landfills are typically lined by law, although many older ones are not. Methane production even from large landfills is relatively low; as a result, power facilities that use it are typically small systems located on site using fuel cells, microturbines, or reciprocating engines.

For all of these technologies, except landfill gas, a power plant will require feedstock storage space, feedstock preparation equipment, feed equipment, processing equipment, product cleaning and collection equipment, electricity generation equipment, ash and waste storage space, water for steam and cooling, and emissions control equipment. The specific infrastructure and space required for each of these depends on the type of feedstock and process used and on existing site conditions. Some feedstocks require year-round storage, as they are only available seasonally (e.g., agricultural residue); some feedstocks are available almost continuously and require less storage space (e.g., municipal solid waste). The size of the system will depend on the amount of feedstock available. As an example of space needed, one plasma gasification project we evaluated could process 250 tons of MSW in an 80-ft by 175 -ft area, not including storage space. Any existing electrical generation equipment may be able to 
be used with a new gasification system, reducing site requirements, only needing sufficient space next to the existing system for the new equipment and connection lines.

Emissions control requirements depend upon the process used and on regulations affecting the site. Some gasification processes produce no criteria pollutants, such as $\mathrm{SO}_{\mathrm{X}}$ and $\mathrm{NO}_{\mathrm{X}}$. However, air emissions are inevitable if the resulting syngas is burned in a conventional power generator. Air emissions are not expected to pose a problem at Fort Hood.

Fort Hood is a large site with four main substations. There appears to be available space where a biomass plant could be located within a few miles of each substation. The location would also need to be accessible to trucks and possibly near the landfill if using MSW.

\section{Biomass and Waste-to-Energy Analysis Approach}

The critical factor in determining feasibility for biomass energy generation is feedstock availability. As listed above, there are a number of potential feedstocks, and each one was evaluated for use at Fort Hood. The following questions were asked about each feedstock:

$\checkmark$ Does this material exist in the surrounding region within 60 miles? (30 to 60 miles is assumed to be the maximum economic transport distance.)

$\checkmark$ How much is available within this area, on average? Is availability constant or variable, depending on crop rotation cycles and/or market conditions?

$\checkmark$ How much is available for use as a feedstock? Availability is based on the feedstock being able to be collected and the lack of competing uses or markets. For example, wheat straw it typically left in the field to protect and rebuild the soil. If it is collected, the resulting bales may have higher value as animal bedding than as fuel, creating a competing market for what was otherwise a waste material on the ground.

$\checkmark$ How much electricity can be produced from the available biomass? This is a function of the quantity of material available, moisture content, and its relative heat value.

In this analysis, if the electricity available from a feedstock were less than $1 \mathrm{MW}$, it was not considered a feasible resource. The narrowed list of possible feedstocks was then evaluated on a simple economic basis. Feedstock costs were estimated based on tipping fees, collection costs, transportation costs, current market rates, and other relevant information. Other operational costs and construction costs were estimated by scaling existing plant data for the three primary technology types. Based on the amount of feedstock available and the size of plant required, a levelized cost of electricity was estimated for each.

For any options that are reasonably close to being cost effective, further economic analysis was completed, including evaluating tax credits and other incentives, different financing options, ranges of potential construction and operation costs, and ranges of feedstock costs and amounts. Fort Hood's average electricity cost of $8.5 \$ / \mathrm{kWh}$ was used for this economic analysis.

Any associated risks or potential issues with these remaining options were noted to present all considerations surrounding an implementation decision. When possible, these were quantified. 
PNNL staff created a new tool that supports analyses of various plant sizes, costs, and fuel sources in a generic manner. This facilitates "what if" analyses where critical information about fuel source and cost is unavailable. The result is an estimate of what power from a project would cost using available data and staff assessments for missing data. It also allows staff to reverse engineer an answer using Fort Hood's power cost as a given. Specifically, the tool can be set up to provide an estimate of what size plant and fuel cost is needed to produce power for less than the current and projected future power rate. Data from a 2003 NREL study of biomass fuels was used to initiate the analytic tool. The 2003 study costs were converted into 2007 dollars and scaled according to varying plant sizes following the methodology used in the study. Any size plant can be evaluated and any value can be varied to test for financial feasibility. The tool was only used for preliminary screening because it does not adequately address taxes, incentives, or other factors. These economic factors have a significant impact on project feasibility, especially if it is assumed the power project will not be owned and operated by the government.

This analytic approach was used to evaluate all biomass options, without making preliminary assumptions about any feedstocks or technologies. In other words, it was used to develop preliminary estimates of electric generation costs using a "What if feedstock X were available?" The results of this preliminary analysis are useful for framing a biomass or waste energy strategy. If the analysis resulted in estimated costs that are unrealistically high, the option was rejected.

\section{Biomass and Waste Resource Characterization}

The following biomass and waste types were assessed for potential as feedstocks.

$\checkmark$ Agricultural (crop residues, animal waste, dedicated biomass crops)

$\checkmark$ Forest (thinnings, logging slash)

$\checkmark$ Industrial (mill residue, other industry waste)

$\checkmark$ Waste (MSW, urban wood waste, landfill gas, biogas or biosolids from wastewater treatment plants).

\section{Agricultural Biomass}

The USDA has a database of agricultural production information by county and state. Information was gathered here about corn, wheat, other crops/orchards/vineyards, and poultry, pig, and cow production. Fort Hood is surrounded by farmland that produces corn, wheat, and oats, and raises cattle.

\section{Crop Residue}

Crop residues are the plant remains in the field after harvest. Some crops have more residues than others; some, like hay, have no residues at all because the entire plant is harvested. A certain amount of residue left on the soil minimizes erosion and maintains nutrients in the soil. However, too much residue can inhibit growth of a new crop. Depending on tilling practices, climate, crop type, soil type, and slope of the land, residue may or may not be available for removal. In general, conventional till practices need more residue than no-till practices; warm wet climates need more residue than cold dry climates; corn fields need more residue than wheat fields; coarse, well-drained soils need more residue than poorly-drained, heavy clay soils; and steeper slopes need more residue than flat land. In addition, crop residue availability is dependent on competing uses, like cattle feed, and seasonal yields, which can change dramatically from year to year. 
In 2006 in counties within 60 miles of Fort Hood, 24.8 million bushels of corn, 1.7 million bushels of wheat, and 1.6 million bushels of oats were produced. These harvests left about 687,000 tons of corn stover, 88,000 tons of wheat straw, and 32,000 tons of oat residue on the fields. Available residue for biomass will be somewhere between these values and zero. It can be assumed for now that about $30 \%$ of the residues can be collected, resulting in about 206,000 tons of corn stover, 26,000 tons of wheat straw, and 10,000 tons of oat residue available for use. These numbers will have to be verified on a farm-by-farm basis for a more accurate analysis.

This amount of corn stover could be used to generate 18 to $23 \mathrm{MW}$ of electricity. The wheat straw could generate 2 to $3 \mathrm{MW}$, and the oat residue could generate about $1 \mathrm{MW}$. In total, crop residues could generate 20 to $27 \mathrm{MW}$ of electricity.

It would cost about $\$ 10 /$ ton to transport the residues to the plant, and about $\$ 10 /$ ton for the farmer's collection effort. Therefore, crop residue feedstock cost is about \$20/ton. Using all crops together to gain the most benefit from economy of scale, the most cost-effective biomass option would be gasification, producing electricity at $10 \$ / \mathrm{kWh}$. This is more expensive than Fort Hood's commercial rate, and is not an economic option at this time.

In addition, residue availability is dependent on competing uses, including cattle feed, which can pay almost \$42/ton for corn stover and over \$21/ton for wheat straw. Availability is also dependent on seasonal yields, which can change dramatically. Sufficient on-site storage of the residue is important to avoid incurring further costs for storage elsewhere. A significant amount of space is required to store crop residue, as it is only available twice a year, after harvest.

In conclusion, crop wastes are potentially available for use as biomass feedstock; however, the cost of electricity generated from these wastes is not competitive with commercial rates. In addition, annual crop yield varies because of crop rotation, market conditions, and weather patterns such that the volume of crop-specific feedstock is highly variable. This increases the risk that sufficient fuel will not be available on an annual basis. Finally, there are alternative markets that provide intervening opportunities in terms of market access (alternative markets are closer to the source) and market price. Therefore, it is not recommended to pursue corn, wheat, or oats as biomass resources.

\section{Animal Waste}

Manure from cattle, swine, and poultry farms is generally cleaned out of housing and feeding areas and used as fertilizer for crops. This has become a problem because of over-application. Bad odors and groundwater contamination are forcing farmers to find other ways to dispose of manure. Anaerobic digestion technologies can turn wet manure into energy, and often can be used with existing collection and treatment systems. Poultry waste has much lower moisture content than cow or swine manure, and can be used in combustion or gasification systems.

In 2006, there were no cattle feed lots within 60 miles of Fort Hood. All 524,000 cattle were kept in pastures (including the cattle on 200,000 acres of grazing land leased to farmers by Fort Hood). Manure in pastures is not good feedstock material because it is not typically collected (increasing the costs and decreasing the heating value as it dries in the field). Only the manure from cattle on a feedlot can be assumed to be available for electricity generation, and there are none within economic range of the Fort. 
If all cattle and calves in the area were considered, assuming that they may also spend some time in a feedlot, the manure could generate $73 \mathrm{MW}$ of electricity. However, using manure to generate energy at any distance from the source will not be cost effective. Cow manure is only $12 \%$ solids as excreted, and then is typically collected with a flush system, watering it down even further. On a dry basis, manure has an energy content of about $17 \mathrm{MMBtu} / \mathrm{ton}$, and is transportable; but wet manure has an energy content of about $2 \mathrm{MMBtu} /$ ton or less. Drying the manure on site would incur costs to the farm, and then the manure would have to be sold at a profit for the farmer. These costs would be in addition to transportation costs, which would typically be about $\$ 10 /$ ton. Transporting wet manure would increase costs (because of increased volume and hence increased number of trucks) beyond what is economically feasible. Because of the expenses of liquid removal, transportation, and anaerobic digestion equipment, using manure for energy generation at Fort Hood is not feasible.

\section{Dedicated Crops}

Dedicated energy crops include switchgrass, hybrid poplar, willow coppice, and other SRWC (short rotation woody crops). These are fast-growing plants that can be harvested for use as energy in various forms. Switchgrass is a native prairie grass that grows best in warm dry climates like the Midwest. SRWC need lots of water and do well in colder climates like the Northeast. They need at least 16 inches of rainfall per year, or need to be located on a body of water. Using dedicated crops as biomass is an option, but they are not a readily available resource. Rather, agricultural land where the crops can be grown is the resource to be evaluated, and the feedstock cost would be based on the cost to farm that land, harvest the resource, and deliver it to the generation plant on post.

SWRC would not grow well near Fort Hood, but switchgrass is native to the area. According to Ugarte, et al., the production costs of switchgrass in the Fort Hood region would average \$21.99/ton plus a transportation cost of $\$ 10 /$ ton. At this price, it would require a 110-MW gasification plant to generate cost-effective electricity, using over one-half million tons of switchgrass per year. At a yield of 4.3 tons/acre, the land requirement would be about 120,000 acres. This land could come from converting some or all of the current grazing land on Fort Hood; otherwise, sufficient land does not appear to be available in the Fort Hood region.

\section{Forest Biomass}

\section{Forest Thinnings and Logging Slash}

Logging slash includes branches, stumps, and other material that is generated during logging practices but left behind because it is not useful to the loggers looking for large tree trunks. Once this slash is cut and left on the forest floor, it dries out, becoming good fuel for fires. It also can get in the way of machinery during replanting efforts. Sometimes it is gathered into small piles and burned in a controlled manner to reduce the risk of widespread forest fire, but this practice pollutes the air and may be restricted by air quality regulations. Instead, it can be collected and transported to a biomass facility where the emissions can be controlled and the wood waste can be put to good use.

Forested areas near Fort Hood are limited, but there are a few. There were about 11,000 tons of slash left in the forests within 60 miles of Fort Hood in 2006. Assuming a recoverability factor of $50 \%$ because of site accessibility, steepness of slopes, and retrieval efficiency, about 5,500 tons are available. This amount could power a plant of only about $0.75 \mathrm{MW}$.

Forest resources are also limited on post. Mesquite and juniper grow on Fort Hood, but mesquite is protected because it is habitat for endangered species. Juniper is an invasive species, whose growth is 
stimulated by training activities. There is an active program to control this growth, primarily through hand-cutting and prescribed burning when the trees are small, and through mechanical methods when the trees grow larger. The cuttings are burned when they can't be reached by the mulching machine, but otherwise mulched and used for ground cover on site. Tree trimmings from the cantonment area are mulched with pallets and used as mulch for family housing, or composted. This woody waste is kept on site grounds to return the nutrients to the soil. Therefore, no thinnings or other woody waste is available for biomass use on Fort Hood. Forest residue is not a feasible option for energy production at Fort Hood.

Industrial Biomass

Industrial biomass includes mill residue, food processing waste, textile waste, or waste from other specialized operations.

\section{Mill Residue}

There are many types of mills that use wood to produce various products, including lumber, shake and shingle, pulp, veneer and plywood, log chips, and posts, poles, and pilings. These processes generate waste in the form of sawdust and wood pieces, which are useful materials. In fact, most mill residue is currently used for fiber, fuel, or other uses. There are no mills in the Fort Hood region.

\section{Other Residue}

There are a number of small businesses near Fort Hood that produce woody or fibrous waste that would be useful for generating energy. Conversations with a few of these surrounding industrial facilities showed that over 10,000 tons of waste might be available on an annual basis. Assuming an average heat content of $10 \mathrm{MMBtu} / \mathrm{ton}$, almost 7,000 to about 9,000 tons of industrial waste would be needed per MW of electrical generation power. In order to build a plant that would produce only 1 to $2 \mathrm{MW}$ of electricity at the Fort Hood commercial rate, suppliers would have to pay Fort Hood to take their waste away, at rates of over $\$ 60 /$ ton. Unfortunately, this would not be feasible; many of the businesses are looking to sell their waste products. Using other industrial residues is not a viable option for Fort Hood.

\section{Landfill Gas}

Methane generated from decomposing waste is a combustible pollutant that must be controlled. It is typically vented or collected and flared to avoid buildup and hence, danger of explosion. Collected methane can also be used as a fuel to generate heat or electricity.

Fort Hood's landfill opened in 1992 and only has one cell closed so far, with two active cells. One of these will close in about 2 years, and the other will close 5 years after that. The landfill currently has about 795,000 tons of waste in place, and has a permitted capacity for 3.3 million tons, allowing it to remain active until around 2096.

There are no methane collection requirements for this region, so the closed cell is only vented through four vents. One of the vents has a pipe system to the bottom of the cell because of a previous methane leak investigation. These vents currently release approximately 140,000 kcf of methane per year, with a modeled maximum potential of 153,000 kcf per year to be reached in 2071 . Between 60 and $80 \%$ of this could be recoverable, resulting in less than $1 \mathrm{MW}$ of electricity production in the near future, and just over $1 \mathrm{MW}$ at the maximum. This is not a large enough project to be considered for development. 
In the case of a waste-to-energy plant being built, the landfill would be capped in the next few years and no more waste would be added. The total amount of waste in place would be less than 1 million tons, and a landfill gas project would not be cost effective at a landfill this small.

\section{Waste Biomass}

\section{Municipal Solid and Urban Wood Waste}

Municipal solid waste (MSW) and construction and demolition (C\&D) waste are being generated at greater rates each year while landfills are filling up, resulting in greater hauling distances and increasing prices for waste disposal. Recycling is one way to reduce the strain on landfills; using the waste to generate energy is another. Some recyclables, like metals, must be separated out before waste is used for energy generation. All carbon-based materials, however, can be used to generate energy.

Fort Hood produces approximately 25,000 tons of MSW per year that goes to the landfill, including waste from family housing. The Killeen Transfer Station processes over 95,000 tons of waste per year, and is located just outside of Fort Hood in Bell County. Copperas Cove Transfer Station is also nearby, just across the county line in Coryell County, and processes almost 26,000 tons of waste each year. The Temple Landfill collects almost 264,000 tons of waste each year, and is located in Bell County less than 10 miles from Fort Hood. These are summarized, with their respective tipping fees, in Table B-1. The Copperas Cove tipping fee is unknown; for the purposes of this analysis, $\$ 0$ is assumed as a conservative estimate.

Using Fort Hood, Killeen, and Copperas Cove waste, the MSW could generate up to 21 MW of electricity. Fort Hood waste only could produce up to $4 \mathrm{MW}$. Temple Landfill waste could generate up to $36 \mathrm{MW}$. Therefore, adequate waste is theoretically available for a waste-to-energy plant.

The easy option is to use only Fort Hood's waste, but because of the small amount available, the costeffective options will be limited here. The second option is using the nearby transfer station waste with Fort Hood's waste, to improve economy of scale but also maintain relatively high tipping fees for increased plant revenue. This option will require some discussion with the surrounding communities and transfer stations to determine how much waste could be made available, and their willingness to pass on some or all of the tipping revenue. 
Table B.1: Municipal Solid Waste Near Fort Hood

\begin{tabular}{||l|l|c|c|c||}
\hline \multicolumn{1}{|c|}{ Site } & \multicolumn{1}{|c|}{$\begin{array}{c}\text { Collection } \\
\text { Location }\end{array}$} & $\begin{array}{c}\text { Miles from } \\
\text { Hood }\end{array}$ & $\begin{array}{c}\text { Tipping } \\
\text { Fee (\$) }\end{array}$ & $\begin{array}{c}\text { Available } \\
\text { MSW } \\
\text { (tons/year) }\end{array}$ \\
\hline \hline Fort Hood & Fort Hood & 0 & $\$ 38.46$ & 25,000 \\
\hline Killeen Transfer Station & Killeen, TX & 1 & $\$ 51.40$ & 95,000 \\
\hline $\begin{array}{l}\text { Copperas Cove Transfer } \\
\text { Station }\end{array}$ & Copperas Cove, TX & 5 & Unknown & 26,000 \\
\hline Temple Landfill & Temple, TX & 10 & $\$ 2.40$ & 264,000 \\
\hline \multicolumn{1}{|l}{} & & TOTAL & $\mathbf{4 1 0 , 0 0 0}$ \\
\hline
\end{tabular}

A third option would be using Temple Landfill's waste, either alone or with the other waste. This waste is not as attractive because of the low tipping fees, but it could greatly improve economies of scale. Discussions would also be needed here to determine availability of the waste and tipping revenue.

The technologies considered for waste conversion include combustion, gasification, and plasma melting. Combustion releases more emissions than the other options, making it less desirable and more difficult to permit. One technology, the zero-emission energy recycling oxidation system (ZEROS), has been proposed to Fort Hood for use on site and is similar to the plasma melting process considered here. A discussion of the ZEROS process and proposal is provided below.

C\&D waste is included with MSW in this region. C\&D-only landfills are not located near Fort Hood, and are not being considered separately. 


\section{Wastewater Treatment Plant (WWTP) Sludge}

WWTP sludge is the remains after wastewater is treated and the clean water is returned to the ground or other body of water. It has a high-energy content when dried, but the drying process is energy-intensive and necessary for any transportation. Sludge is similar in substance to manure; it is a very watereddown substance that is best processed on site, where energy is generated with anaerobic digestion. Therefore only on-site sources of sludge are reasonable to use for energy generation.

Fort Hood does not have a wastewater treatment plant on site; wastewater is sent to Killeen to be treated. Therefore, anaerobic digestion of WWTP sludge is not a viable option.

\section{ZEROS Discussion}

A waste-to-energy facility has been proposed for Fort Hood and the City of Killeen. The facility would use the proprietary ZEROS technology to generate $39 \mathrm{MW}$ of electricity, at an estimated (by ZEROS) 5.8-6.0 $\$ / \mathrm{kWh}$. The technology is a gasification-oxidation system, in which the MSW will be gasified and then oxidized to produce $\mathrm{CO}_{2}$ and steam. The steam is used to produce electricity, and the $\mathrm{CO}_{2}$ is extracted as a liquid. It can be sold along with the other byproducts, including nitrogen, hydrogen, metals, volcanic-like glass, distilled water, and fly ash. The sale of these byproducts allows the electricity to be sold at a relatively low price.

This system seems to be an attractive process that would allow Fort Hood to purchase inexpensive electricity at no additional cost, if all assumptions are valid. However, there are a few issues that should be investigated prior to any agreements being made.

$\checkmark$ This unit needs to process 346,239 tons of MSW per year. Fort Hood only produces 25,000 tons of MSW per year and Killeen produces 95,000 tons per year. There is no mention of other sources of MSW. Temple Landfill collects 264,000 tons of MSW per year, which may be an additional source but has a much lower tipping fee. Copperas Cove only generates about 25,500 tons per year, and other surrounding communities are similarly small. The costs of transport must also be incorporated into the costs gained from tipping fees.

$\checkmark$ The assumed Btu value for MSW (6,500 Btu/lb) is high. A better assumption is 5,000 Btu/lb, although this may also be high, depending on the waste contents.

$\checkmark$ A more detailed explanation of the technology needs to be obtained and reviewed. For example, it is not clear how the chambers are maintained at such high temperatures.

$\checkmark$ This technology is new and therefore high risk. Third-party ownership and operation will mitigate this risk; however, it must be emphasized that technologies with minimal testing or previous operation tend to have increased problems and operational issues. What will be done to minimize or eliminate the effect on Fort Hood?

$\checkmark$ Because the price of electricity is dependent on sale of other byproducts, a market for these byproducts should be demonstrated.

$\checkmark$ No cost estimates were made for land acquisition. Is Fort Hood donating the land? Or will it be leased (and therefore increase operational costs)?

$\checkmark$ There is no mention of how the wastewater would be transported to the site. Who would build the pipelines, and where would they be located? 
These are just a few concerns based on a review of limited information provided about the proposed technology. If Fort Hood is seriously considering pursuing this option, these concerns should be addressed, and a detailed critical review needs to be completed. It is recommended to further investigate this option, but not commit to anything until all concerns are resolved.

\section{Biomass and Waste-to-Energy: Economic and Other Analysis Parameters}

Data used in this analysis were obtained from local sources when possible, and the economic assumptions were generally conservative. The economic performance of MSW plants determined through a more detailed, design-level analysis should lie in the same ballpark as results presented here. Our assumptions are presented in the report. However, any significant changes to important assumptions may change outcomes-opportunities that are barely economic in this report may no longer be economic if the values are changed significantly.

\section{Findings: Biomass and Waste-to-Energy Opportunities}

The following biomass fuels are not worth pursuing because of a lack of resource availability:

$\checkmark$ Animal waste

$\checkmark$ Forest thinnings \& logging slash

$\checkmark$ Mill residue

$\checkmark$ WWTP sludge

$\checkmark$ Landfill gas.

The following biomass fuels are not worth pursuing because of unfavorable economics:

$\checkmark$ Crop residue $(10 \$ / \mathrm{kWh})$

$\checkmark$ Dedicated biomass crops (not enough land available to produce cost-effective amount)

$\checkmark$ Other industrial waste (requires suppliers to pay over $\$ 60 /$ ton for removal).

MSW, including urban waste wood, is the best option for generating electricity at Fort Hood. Project economics will depend on the availability and price of waste, and actual plant size, capital costs, and operating costs. The economic assumptions used to analyze each scenario are listed in Table B-2. The assumptions that vary per scenario are listed below with the results. The average cost of electricity that Fort Hood would pay for the renewable energy was assumed to be $8.5 \$ / \mathrm{kWh}$. Because Texas is a deregulated state, power from a biomass or waste power plant could be purchased from nearby rather than produced on site. That would add some transmission costs to the delivered price of power, but may avoid challenges presented by locating a plant on site. 
Table B.2: Economic Assumptions, constant \$2007

\begin{tabular}{|c|c|}
\hline \multicolumn{2}{|l|}{ Economic Factors } \\
\hline Inflation & $1.9 \%$ \\
\hline Interest Rate & $10.0 \%$ \\
\hline Debt/Equity Ratio & N/A \\
\hline Real Discount Rate & $3.0 \%$ \\
\hline \multicolumn{2}{|l|}{ Tax Considerations } \\
\hline Federal Depreciation & MACRS \\
\hline Federal Tax Rate & $35 \%$ \\
\hline Texas State Income Tax Rate & $1.0 \%$ \\
\hline State Sales Tax & $6.75 \%$ \\
\hline $\begin{array}{l}\text { Property Tax Rate (Combustion } \\
\text { Technologies) }\end{array}$ & $0.5 \%$ \\
\hline $\begin{array}{l}\text { Property Tax Rate (Gasification } \\
\text { Technologies) }\end{array}$ & $0.0 \%$ \\
\hline \multicolumn{2}{|l|}{ Incentives } \\
\hline Federal Production Tax Credit & $\$ 0.01 / \mathrm{kWh}$ \\
\hline State Production Tax Credit & $\$ 0.00 / \mathrm{kWh}$ \\
\hline Federal Energy Tax Credit & $0 \%$ \\
\hline State Energy Tax Credit & $0 \%$ \\
\hline Utility Rebate & $\$ 0 / \mathrm{kW}$ \\
\hline \multicolumn{2}{|l|}{ Technology } \\
\hline Plant Life & 30 years \\
\hline $\begin{array}{l}\text { Capacity Factor (basis net kW } \\
\text { output): Total System }\end{array}$ & $85 \%$ \\
\hline $\begin{array}{l}\text { Real Escalation in Construction } \\
\text { Cost }\end{array}$ & $0 \%$ \\
\hline $\begin{array}{l}\text { Misc. Depreciable Cost (last } \\
\text { year of construction) }\end{array}$ & $\$ 0$ \\
\hline $\begin{array}{l}\text { Sales Tax on Misc. Depreciation } \\
\text { Cost }\end{array}$ & $\$ 0$ \\
\hline Land Cost & $\$ 0 / \mathrm{kW}$ \\
\hline Startup Cost & $\$ 0 / \mathrm{kW}$ \\
\hline
\end{tabular}

As previously mentioned, there are multiple options to consider when using MSW for energy production: site waste only, site waste with city transfer station waste, site waste with landfill waste, and all waste. In addition, each of these options can use combustion, gasification, or plasma melting. The combinations that are cost effective or close to cost effective are presented in Tables B-3 and B-4. 
Table B.3: MSW Waste-to-Energy Results for Combustion Technologies

\begin{tabular}{|c|c|c|c|c|}
\hline Waste Source(s) & Hood & $\begin{array}{l}\text { Hood, Killeen TS, } \\
\text { Copperas Cove TS }\end{array}$ & $\begin{array}{c}\text { Hood, } \\
\text { Temple LF }\end{array}$ & All \\
\hline Technology & Combustion & Combustion & Combustion & Combustion \\
\hline Plant Size & $2.75 \mathrm{MW}$ & $16.1 \mathrm{MW}$ & $31.8 \mathrm{MW}$ & $45.1 \mathrm{MW}$ \\
\hline Feedstock Amount & 25,000 tons/yr & 145,898 tons/yr & $\begin{array}{c}288,882 \\
\text { tons/yr }\end{array}$ & 409,780 tons/yr \\
\hline Total Plant Cost & $\$ 4860.9 / \mathrm{kW}$ & $\$ 3415.8 / \mathrm{kW}$ & $\$ 2979.6 / k W$ & $\$ 2778.4 / \mathrm{kW}$ \\
\hline Capital Cost & $\$ 4553.5 / \mathrm{kW}$ & $\$ 3199.8 / \mathrm{kW}$ & $\$ 2791.2 / \mathrm{kW}$ & $\$ 2602.7 / \mathrm{kW}$ \\
\hline Sales Tax & $\$ 307.4 / \mathrm{kW}$ & $\$ 216.0 / \mathrm{kW}$ & $\$ 188.4 / \mathrm{kW}$ & $\$ 175.7 / \mathrm{kW}$ \\
\hline Fixed O\&M Cost & $\$ 234.6 / \mathrm{kW}$ & $\$ 102.9 / \mathrm{kW}$ & $\$ 89.38 / \mathrm{kW}$ & $\$ 85.32 / \mathrm{kW}$ \\
\hline Variable O\&M Cost & $-3.5 \$ / k W h$ & $-3.6 \$ / k W h$ & $0.56 \$ / k W h$ & $-0.70 \$ / \mathrm{kWh}$ \\
\hline Feedstock Cost & \$38.46/ton & \$40/ton & $\$ 5.52 /$ ton & \$15.86/ton \\
\hline SIR & 1.0 & 2.5 & 1.6 & 2.2 \\
\hline Simple Payback & 13.4 years & 5.6 years & 8.5 years & 6.3 years \\
\hline Internal Rate of Return (IRR), No Financing & $9.05 \%$ & $20.55 \%$ & $15.16 \%$ & $19.47 \%$ \\
\hline
\end{tabular}


Table B.4: MSW Waste-to-Energy Results for Gasification and Plasma Melting Technologies

\begin{tabular}{|c|c|c|c|c|}
\hline Waste Source(s) & $\begin{array}{l}\text { Hood, Killeen TS, } \\
\text { Copperas Cove TS }\end{array}$ & $\begin{array}{l}\text { Hood, } \\
\text { Temple LF }\end{array}$ & All & $\begin{array}{c}\text { Hood, Killeen TS, Copperas } \\
\text { Cove TS }\end{array}$ \\
\hline Technology & Gasification & Gasification & Gasification & Plasma Melting \\
\hline Plant Size & $21.2 \mathrm{MW}$ & $42.1 \mathrm{MW}$ & $59.7 \mathrm{MW}$ & $10.9 \mathrm{MW}$ \\
\hline Feedstock Amount & 145,898 tons/yr & 288,882 tons/yr & $\begin{array}{c}409,780 \\
\text { tons/yr }\end{array}$ & 145,898 tons/yr \\
\hline Total Plant Cost & $\$ 3492.5 / \mathrm{kW}$ & $\$ 3046.5 / \mathrm{kW}$ & $\$ 2840.8 / \mathrm{kW}$ & $\$ 6948.4 / \mathrm{kW}$ \\
\hline Capital Cost & $\$ 3271.7 / \mathrm{kW}$ & $\$ 2853.9 / \mathrm{kW}$ & $\$ 2661.2 / \mathrm{kW}$ & $\$ 6509.0 / \mathrm{kW}$ \\
\hline Sales Tax & $\$ 220.8 / \mathrm{kW}$ & $\$ 192.6 / \mathrm{kW}$ & $\$ 179.6$ & $\$ 439.4 / \mathrm{kW}$ \\
\hline Fixed O\&M Cost & $\$ 171.3 / \mathrm{kW}$ & $\$ 106.4 / \mathrm{kW}$ & $\$ 84.03 / \mathrm{kW}$ & $\$ 276.7 / \mathrm{kW}$ \\
\hline Variable O\&M Cost & $-3.1 \Phi / k W h$ & $0.12 థ / k W h$ & $-0.83 \$ / k W h$ & $-6.6 \$ / k W h$ \\
\hline Feedstock Cost & $\$ 40 /$ ton & $\$ 5.52 /$ ton & $\$ 15.86 /$ ton & \$40/ton \\
\hline SIR & 1.8 & 1.6 & 2.2 & 1.0 \\
\hline Simple Payback & 7.8 years & 8.7 years & 6.3 years & 13.9 years \\
\hline $\begin{array}{l}\text { Internal Rate of } \\
\text { Return (IRR), No } \\
\text { Financing }\end{array}$ & $16.16 \%$ & $15.22 \%$ & $19.82 \%$ & $8.54 \%$ \\
\hline
\end{tabular}

These scenarios show that a number of options are available to Fort Hood. For only non-combustion options, which are preferred because of reduced emissions, using all regional waste is the most economic choice. However, the increased energy production and more attractive economics must be weighed against the increased difficulty of obtaining and storing all of the additional waste, and the need to manage more contracts and more traffic on site. Only Fort Hood can determine which way to go.

The scenarios assume that all waste collected or processed at these facilities will be available, at the price currently paid for disposal. These total amounts may not be available, and these total revenues may not be available, possibly resulting in less attractive options. Because the Copperas Cove tipping fee was unknown and assumed to be $\$ 0$, options using this waste may be more attractive if an existing tipping fee can be avoided.

\section{Biomass and Waste-to-Energy: Next steps}

Using MSW to generate electricity is a potentially viable option for Fort Hood and should be pursued. The ZEROS proposal should be critically reviewed, and questions posed above answered, at a minimum. Whether this proposal is accepted or not, the following steps must occur in order to implement a waste-to-energy plant.

Find a location for the plant. A site is needed that is large enough for the equipment, feedstock storage, and access, can be accessed by trucks for feedstock delivery (both on site and off site), and can be connected to the site electric grid. 
Quantify the waste that is realistically available. The regional waste collection entities need to be approached in order to characterize potential waste quantities and prices. This may be the determining factor as to which option is pursued.

If the ZEROS process is not selected for implementation as an unsolicited proposal, the potential interest of other developers should be assessed via a request for information (RFI) or other process. Once the development interest and feedstock source for the energy are secured, plans can proceed with the design and final economic calculations.

It is not recommended to pursue other options at this time.

\section{Biomass and Waste-to-Energy References}

Aabakken, J. “Power Technologies Energy Data Book.” National Renewable Energy Laboratory. Fourth Edition. NREL/TP-620-39728. August 2006.

Askey, Phil. "Diversion Trends and Opportunities on the Horizon.” 2007 MORA Conference. Johnson County Environmental Department. 2007. http://www.mora.org/docs/conference/2007Presentations/Phil_Askey-DiversionTrends.pdf.

Bain, RL, et al. "Biopower Technical Assessment: State of the Industry and Technology.” National Renewable Energy Laboratory. NREL/TP-510-33123. March 2003.

Burke, Dennis. “Dairy Waste Anaerobic Digestion Handbook.” Encyclopedia of Animal Science. Environmental Energy Company. June 2001. http://www.makingenergy.com/Dairy\%20Waste\%20Handbook.pdf.

City of Killeen. "Public Works / Solid Waste / Transfer Station." http://www.ci.killeen.tx.us/index.php?section=120. Accessed February 2008.

Cornelius, John, Fort Hood Chief of Natural Resources. Personal communications. March 2008.

Database of State Incentives for Renewables and Efficiency. "Texas Incentives for Renewables and Efficiency."

http://www.dsireusa.org/library/includes/map2.cfm?CurrentPageID=1\&State=TX\&RE=1\&EE=1. Accessed March 2008.

Energy Information Administration. "Average Heat Content of Selected Biomass Fuels." http://www.eia.doe.gov/cneaf/solar.renewables/page/trends/table10.html. Accessed September 2007.

Environmental Protection Agency Landfill Methane Outreach Program. http://www.epa.gov/lmop/proj/index.htm. Accessed October 2007.

Frazier, Edwin, Fort Hood General Engineer. Personal communications. February 2008.

Gallagher, Paul, et al. "Biomass from Crop Residues: Cost and Supply Estimates.” United States Department of Agriculture, Office of the Chief Economist. February 2003. http://www.usda.gov/oce/reports/energy/AER819.pdf. 
Haq, Zia. “Biomass for Electricity Generation.” Energy Information Administration. July 2002. http://www.epa.gov/solar/pdf/haq apr20.pdf.

IEA Energy Technology Essentials. "Biomass for Power Generation and CHP.” http://www.iea.org/textbase/techno/essentials3.pdf. January 2007.

Lamar, David, Integrated Environmental Technologies, LLC. Personal communications. October 2007. Lynn, Bobby, Fort Hood Energy Manager. Personal communications. February 2008.

McDaniel, Edward, Engineer. ES Alternatives. Personal communications. March 2008.

Research Reports International. “The Use of Biomass for Power Generation in the U.S.” July 2007.

Salmon, Jeff, Fort Hood MSW Management. Personal communications. March 2008.

Shanahan, J.F., et al. “Crop Residues for Livestock Feed.” Colorado State University Extension Agriculture. http://www.ext.colostate.edu/pubs/CROPS/00551.html. September 1998.

Smith, Carl Benjamin, et al. "Lesser Known Energy Sources: A Study of Biogas and Tire Based Fuel.” Lockheed Martin. September 2007.

http://www.aeecenter.org/DivisionNewsletters/AREDI/Fall07/biogas-tires.pdf.

Soil Quality National Technology Development Team. "Crop Residue Removal for Biomass Energy Production: Effects on Soils and Recommendations.” National Resources Conservation Service. http://soils.usda.gov/sqi/management/files/sq_atn_19.pdf. August 2006.

State Energy Conservation Office. "Energy Crops for Fuel.”

http://www.seco.cpa.state.tx.us/re_biomass-crops.htm. Accessed February 2008.

Stone, Robert, et al. "Universal Soil Loss Equation (USLE).” Ministry of Agriculture, Food and Rural Affairs. http://www.omafra.gov.on.ca/english/engineer/facts/00-001.htm\#tab2. May 2000.

Systems International, Inc. “50 MW Waste to Energy Killeen/Ft Hood Project.” ZEST-TX, LLC. January 2008.

Systems International, Inc. “Killeen/Ft Hood Waste to Energy Plant Proforma.” ZEST-TX, LLC. January 2008.

Texas Commission on Environmental Quality. "Municipal Solid Waste in Texas: A Year in Review 2006 Data Summary and Analysis.” Waste Permits Division. http://www.tceq.state.tx.us/assets/public/comm_exec/pubs/as/187 07.pdf. November 2007.

Texas Environmental Profiles. "Forestland in Texas.” http://www.texasep.org/html/lnd/lnd 3for.html. Accessed February 2008.

United States Department of Agriculture Forest Service. "Forest Inventory \& Analysis Mapmaker Program on Timber Products Output Studies.” http://www.fia.fs.fed.us/program-features/tpo/. Accessed February 2008. 
United States Department of Agriculture National Agricultural Statistics Service.

http://www.nass.usda.gov/Data and Statistics/Quick Stats/. Accessed February 2008.

United States Environmental Protection Agency. Turning a Liability into an Asset: A Landfill Gas-toEnergy Project Development Handbook. Landfill Methane Outreach Program. September 1996.

Walsh, Marie E., et al. "Biomass Feedstock Availability in the United States: 1999 State Level Analysis.” Oak Ridge National Laboratory. January 2000.

http://bioenergy.ornl.gov/resourcedata/index.html. 
Renewable Energy Opportunities at Fort Hood, Texas Pacific Northwest National Laboratory, June 2008

B. 18 
APPENDIX C

Analysis of Geothermal Power Plant Opportunities 
Renewable Energy Opportunities at Fort Hood, Texas Pacific Northwest National Laboratory, June 2008 


\section{Appendix C: Analysis of Geothermal Power Plant Opportunities}

\section{Geothermal Power Plant Technology}

Geothermal power plants use steam from hot water reservoirs found deep below the Earth's surface. The steam rotates a turbine that activates a generator, producing electricity. There are three commercial types of geothermal power plants used to generate electricity (dry steam, flash steam, and binary cycle), and several newer technologies are entering the marketplace (hot dry rock and engineered geothermal systems). They type of plant depends on the state of the fluid (whether it is steam, hot water, or mixed) and its temperature.

$\checkmark$ Dry Steam power plants use underground steam piped directly from wells to the power plant, where it passes through separators to remove small particles before it is directed into a turbine/generator unit. There are only two known underground resources of steam in the United States: The Geysers in northern California and Yellowstone National Park in Wyoming. The only dry steam plants in the country are at The Geysers.

$\checkmark$ Flash Steam power plants use geothermal resources that produce high-temperature hot water or a combination of steam and hot water. This very hot water (reservoirs greater than $360^{\circ} \mathrm{F}$ or $182^{\circ} \mathrm{C}$ ) flows up through wells in the ground under its own pressure. As it flows upward and the pressure decreases, some of the hot water boils (flashes) into steam. The steam is then separated from the water and used to power a turbine/generator. Any leftover water and condensed steam are injected back into the reservoir, making this a sustainable resource. Depending on the temperature resource, is may be possible to use a second flash tank where more steam at a lower pressure is separated for generation (double flash plant).

$\checkmark$ Binary Cycle power plants utilize a second fluid in a closed cycle to operate the turbine, instead of direct geothermal steam. These plants operate on water at lower temperatures of about $225^{\circ}$ to $360^{\circ} \mathrm{F}\left(107^{\circ}\right.$ to $\left.182^{\circ} \mathrm{C}\right)$. The heat from the hot water is used to boil a working fluid, usually an organic compound with a low boiling point. The working fluid is vaporized in a heat exchanger and used to turn a turbine. The water is then injected back into the ground to be reheated. The water and the working fluid are kept separated during the whole process, so there are minor or no air emissions. The advantage of the Binary Cycle plant is that it can operate with lower temperature water by using working fluids that have an even lower boiling point than water. Binary power plants are available in smaller scales such as 200 to 1,000 kW.

$\checkmark$ Hot Dry Rock (HDR) geothermal production utilizes high temperature rocks found deeper (several kilometers) below the surface by pumping high-pressure water down a borehole into a heat zone. The water captures the heat of the rock by traveling through fractures until it is forced out a second borehole and used to generate electricity. Once the water has cooled, it is pumped back underground to heat up again. This process is most easily utilized in locations with natural geothermal systems with existing cracks or pore spaces.

$\checkmark$ Engineered or Enhanced Geothermal Systems (EGS). In locations where there are some cracks and connected pore spaces, or little to no cracks or connectivity, cracks can be created or enhanced. The advantage of HDR or EGS is that geothermal resources can be captured for production in non-tectonically active regions. This technology is still very new and expensive. 


\section{Geothermal Energy Analysis Approach}

In the 2004 DoD Renewable Energy Assessment, the Navy's Geothermal Office was responsible for the DoD geothermal power assessment. That task was subcontracted to Innovative Technical Solutions, Inc. (ISTI). The Navy and ISTI ranked installations based on their assessment of potential. The utility grade geothermal assessment included 18 installations identified by the DoD. Of those installations, five sites were found to have high potential for utility grade systems (ITSI 2003).

Funding limited the number of sites that could be inspected and assessed. ISTI visited some locations and collected information through site inspections (for things like hot springs), field measurements, and review of temperature readings from water well drilling logs. This information was compiled in site reports and used to recommend further analysis, typically the drilling of test wells to measure temperature and assess subsurface conditions (ITSI 2003). Drilling test wells is the next in a progression of steps and is generally very expensive, on the order of $\$ 1$ million per well.

Fort Hood was one of the "utility-scale" geothermal power projects evaluated in the DoD study. We used that information and other available data, including:

$\checkmark$ Existing power plant operation or developer activity

$\checkmark$ One or more wells tested with temperatures in excess of $100^{\circ} \mathrm{C}\left(212^{\circ} \mathrm{F}\right)$ logged downhole (at depths less than $3000 \mathrm{~m}$ )

$\checkmark$ Demonstrated high fluid flow rates on the order of 1000 gallons per minute per MW

$\checkmark$ Heat flow rates greater than $80 \mathrm{~mW} / \mathrm{m}^{2}(\mathrm{~mW}=$ milliWatts and $\mathrm{m}=$ meters)

$\checkmark$ Other exploration data and information available $\left(>=100^{\circ} \mathrm{C}\left(212^{\circ} \mathrm{F}\right)\right.$ not proven $)$

Since the 2003 DoD geothermal assessment, additional R\&D has been done on other geothermal development techniques that may be applicable to additional installations. We attempt to interpret this new information for economic applicability to this list of sites. Expensive drilling tests ( $\sim 1$ million per well) are required to accurately measure temperature and determine subsurface conditions for the actual development of geothermal power plants.

\section{Geothermal Resource Characterization}

Geothermal resources include hot springs and geysers and underground resources of pressurized water and steam accessible via wells, as well as dry steam, hot water, hot dry rocks, and low-temperature geothermal heat. A known geothermal resource area (KGRA) is an area in which the geology, nearby discoveries, competitive interests, or other indicators would show a potential for extraction of geothermal steam or associated geothermal resources are good enough to warrant consideration.

Geothermal wells are drilled to depths of 200 to 1,500 meters for low and medium temperature systems. For high temperature systems, well are drilled 700 to 3,000 meters deep. Each well costs \$1 million to $\$ 4$ million to drill and a geothermal field may consist of between 10 and 100 wells.

For commercial use, it is necessary to have a geothermal reservoir capable of providing hydrothermal (hot water and steam) resources in sufficiently high flow rates. Successful geothermal electrical power generation requires fluid flow rates equal to or greater than 1,000 gpm (gallons per minute) per MW (megawatt). For example, $1.5 \mathrm{MW}$ of electricity at a reservoir temperature of $300^{\circ} \mathrm{F}$ requires a flow rate of about 1,000 gpm, or about 1,029,000 bbs/month (McKenna, USACE) 
Geothermal plants operate in regions with high heat flow rates. Heat flow values above $80 \mathrm{~mW} / \mathrm{m}^{2}$ are considered characteristic of a geothermal system. Productive heat flows are generally greater than 150 $\mathrm{mW} / \mathrm{m}^{2}$ (Blackwell et al. 2003).

Geothermal electrical generation plants are currently operating in Alaska, California, Nevada, Utah, and Hawaii with proposed projects in Arizona, Oregon, Idaho, New Mexico, Texas, Washington, and Wyoming.

There are no operating geothermal power plants in Texas. At one time there was a test plant operating in Brazoria County, which operated between September 1989 and May 1990. The design power plant output was $905 \mathrm{~kW}$. The project was described as a success in the final report (Campbell and Hattar, 1991), but the project was never commercialized because of the low cost of alternative resources at the time, specifically oil and gas. Many things have changed since this time, and developer interest in geothermal energy generation in several regions in Texas has since re-emerged (CEED 2008). However, there is no known developer activity in the region around Fort Hood.

In the ITSI analysis, the Fort Hood utility grade geothermal potential was found to be "low." According to the report:

A designation of low geothermal potential means that the likelihood of utility-grade geothermal production, given knowledge, is low to nonexistent... Relatively low temperatures plus a dearth of other relevant geological features along the Balcones/Ouachita trend indicate that the geothermal potential at Fort Hood, Lackland AFB, and Randolph AFB (all Gulf Coast installations) is low.

The report based this conclusion on the lack of evidence for significant upflow or downflow of groundwater from well in the vicinity of Fort Hood, the relatively low heat flow known to prevail in the area of Fort Hood, and indications that the area occupied by Fort Hood lies outside the designated area of geothermal potential for the Hosston/Trinity aquifer based on probable low temperatures and expected high TDS values (ITSI 2003).

Utility grade geothermal energy requires temperatures in excess of $100^{\circ} \mathrm{C}\left(212^{\circ} \mathrm{F}\right)$ at depths less than 3 km. The Geothermal Temperature at Depth Map for the Continental United States from INL (2005) shows only $75-100^{\circ} \mathrm{C}$ at $3 \mathrm{~km}$ in the Fort Hood area. A Texas specific map produced by the Army Corps of Engineers (McKenna 2006) shows $100^{\circ} \mathrm{C}$ at $4 \mathrm{~km}$ and $126^{\circ} \mathrm{C}$ at $6 \mathrm{~km}$ in the area of Fort Hood. These temperatures are not sufficiently high at shallow enough depth for economic generation using current technology.

Utility grade geothermal energy requires heat flow rates greater than $80 \mathrm{~mW} / \mathrm{m}^{2}$ (milliWatts/square meter). The Southern Methodist University Geothermal Map of the United States (2004) shows heat flow rates of between 55 and $59 \mathrm{~mW} / \mathrm{m}^{2}$ in the area of Fort Hood. This indicates heat flow rate are not sufficient at Fort Hood.

The findings for Fort Hood all contribute to a rating of low potential for utility grade geothermal electricity production. This assessment did not examine the potential for direct use applications of geothermal resources such as space heating, aquaculture, and industrial processes. 


\section{Geothermal Power Plants: Economic and Other Analysis Parameters}

\section{Installed costs of technology}

Geothermal power costs are influenced by capital costs for land, drilling, and the physical plant. Also by the costs for operation and maintenance $(\mathrm{O} \& \mathrm{M})$, the amount of power generated and the market value for the power. Capitol costs range from $\$ 1500$ to $\$ 4000$ per installed $\mathrm{kW}$. Capital costs for flash steam plants tend to be less expensive than binary plants. Plant life spans are typically between 30 and 45 years.

Capitol costs include (WGA 2005):

$\checkmark$ Initial development work: land leasing, exploration, permitting, test well costs

$\checkmark$ Infrastructure: roads, water supply, utilities

$\checkmark$ Well field drilling: production wells in addition to already drilled confirmation wells

$\checkmark$ Steam and brine gathering system: pipes and brine separation equipment

$\checkmark$ Power plant: physical equipment for energy conversion, including substation

$\checkmark$ Interconnection: link of the power plant substation to the transmission corridor

$\checkmark$ Soft costs: developers' fees, overhead, financing costs, legal fees, etc.

Operating plants at over $90 \%$ capacity will result in higher O\&M costs. Larger plant size mean lower O\&M costs. Operating costs range from of 0.4 to $2.6 \$ / \mathrm{kWh}$ costs for conventional power plants (Shibaki 2003, Hance 2005).

\section{Findings: Geothermal Power Plant Opportunities}

According to existing data, Fort Hood lacks naturally occurring hot water/steam fields and elevated temperatures at economic depths (less than $3000 \mathrm{~m}$ ). Fort Hood also lacks sufficient heat flow rates for geothermal energy production. Thus, the economic calculations for geothermal energy production at the installation were not run. At this time, Fort Hood is not a candidate for utility-scale geothermal energy production.

\section{Geothermal Power Plants: Next Steps}

Because there is no viable geothermal resource proximate to Fort Hood, no further action should be taken unless the situation changes dramatically. Factors that could change the situation include:

$\checkmark$ New data emerging demonstrating high temperatures at depths that can be harvested

$\checkmark$ An oil or gas producer found near the post with fluid production at elevated temperatures

$\checkmark$ A reduction in costs for the capture of geothermal energy utilizing newer technologies

$\checkmark$ A reduction in cost for drilling to deeper reservoirs of geothermal heat

$\checkmark$ An large increase in energy prices paid by Fort Hood

Hot Dry Rock or Enhanced Geothermal Systems have potential for the future, but the technology is still new and costly. Consideration could be given to the future potential of developing geothermal reservoirs from co-produced hot waters from oil and gas production. A review of existing oil and gas well production data in Texas shows high water production from oil and gas wells in Texas in general, 
however Bell \& Coryell Counties indicate no water re-injection and only 0 to 6 gpm disposal water flow rates (McKenna 2006). But these data are limited, and it is possible that a nearby producer could be interested in partnering with Fort Hood. If this scenario presents itself, the economics of a coproduction project should be considered.

\section{Geothermal Power Plant References}

Blackwell, David D. et al, Department of Geological Sciences Southern Methodist University, Geothermal Resource Analysis and Structure of Basin and Range Systems, Especially Dixie Valley Geothermal Filed, Nevada. June 2003. http://www.osti.gov/energycitations/servlets/purl/813485smnwbs/native/813485.PDF

California Energy Commission. Renewable Resources Development Report. California Energy Commission Report. November 2003. http://www.energy.ca.gov/reports/2003-11-24_500-03$\underline{\text { 080F.PDF }}$

Campbell, R.G., and M.M. Hatter, 1991, Design and operation of a geopressured geothermal hybrid cycle power plant: Final report vol. I, 180 p. and vol. II, 172; Eaton Operating Company, Inc. and United States Department of Energy, The Ben Holt Co., DOE contract DE-ACO7-85ID12578.

Center for Energy and Economic Diversification (CEED). Geothermal Energy In Gulf Coast Texas. The University of Texas of the Permian Basin. Last modified Monday, March 03, 2008. http://www.utpb.edu/ceed/renewableenergy/gulf_coast_texas.htm

Office of Energy Efficiency and Renewable Energy (EERE). Appendix F - GPRA05 Geothermal Technologies Program Documentation. Projected Benefits of Federal Energy Efficiency and Renewable Energy Programs (FY 2005-FY 2050). 2005.

http://www1.eere.energy.gov/ba/pdfs/gpra fy05 appendix f.pdf

GeothermEx, Inc. Public Interest Energy Research Report. New Geothermal Site Identification and Qualification. California Energy Commission. April 2004. http://www.geothermex.com/CECPIER Report New Geothermal Site Identification and Qualification.pdf

Hance, Cédric Nathanaël. Factors Affecting Costs of Geothermal Power Development. Geothermal Energy Association. August 2005. http://www.geo-

energy.org/publications/reports/Factors\%20Affecting\%20Cost\%20of\%20Geothermal\%20Power\%20De velopment\%20-\%20August \%202005.pdf

Idaho National Laboratory, Temperature at Depth Maps for the Continental United States. Estimated Temperature at 3 Kilometers. 4/12/2005. http://geothermal.id.doe.gov/maps/

Innovative Technical Solutions (ITSI). 2003. Geothermal Energy Resource Assessment on Military Lands. Prepared for NAWS China Lake. Contract No. N68936-02-R-023. October 2003. http://www.geothermal.org/GEO_0001.PDF

Joost J. Brasz, Bruce P. Biederman, and Gwen Holdmann. Power Production from a Moderate Temperature Geothermal Resource. GRC Annual Meeting September 25-28th, 2005; Reno, NV, USA. http://www.yourownpower.com/Power/grc\%20paper.pdf 
McKenna, Jason R. 2006. U.S. Army Corps Engineer Research \& Development Center. Increasing Electrical Power Capacity for Military Applications. U.S. Army Corps Engineer Research \& Development Center. http://www.smu.edu/geothermal/Oil\&Gas/Mckenna_Army\%20Corps.pdf

MIT-led interdisciplinary panel. The Future of Geothermal Energy: Impact of Enhanced Geothermal Systems (EGS) on the United States in the 21st Century. DOE. 2006 http://geothermal.inl.gov/publications/future_of_geothermal_energy.pdf

NOAA Satellite and Information Center. Thermal Springs National Geophysical Data Center. Thermal Springs of the United States. http://map.ngdc.noaa.gov/website/seg/hot_springs/viewer.htm

Petty, Susan. Engineering Geothermal Systems in Oil \& Gas Reservoirs. Presentation at the Southern Methodist University (SMU) Geothermal Lab conference on Geothermal Energy Utilization Associated with Oil and Gas Development. June 12 and 13, 2007.

http://www.smu.edu/geothermal/Oil\&Gas/2007/Petty Susan\%20Engineering\%20Geothermal\%20Syste ms\%20in\%20Reservoirs.pdf

Rafferty, Kevin. Geothermal Power Generation: A Primer on Low-temperature, Small-scale Applications. Geo-Heat Center. January 2000. http://geoheat.oit.edu/pdf/powergen.pdf

Shibaki, Masashi. Geothermal Energy for Electric Power. A Renewable Energy Policy Project (REPP) Issue Brief. December 2003. http://www.crest.org/articles/static/1/binaries/Geothermal_Issue_Brief.pdf

Southern Methodist University Geothermal Lab. Geothermal Map of the United States, 2004 (heat flow map).

http://www.smu.edu/geothermal/heatflow/geothermal_all_us_clipped_150dpi_pagesize_legend.gif

WGA (Western Governors Association) Geothermal Task Force. Near-Term Geothermal Resource Assessment. WGA. November 3, 2005. http://www.geoenergy.org/information/developing/WGA\%20GEOTHERMAL\%20TASK\%20FORCE\%20RESOURC E\%20ASSESSMENT\%20NOV\%203\%2020051.pdf 
APPENDIX D

\section{Analysis of Ground Source Heat Pump Opportunities}


Renewable Energy Opportunities at Fort Hood, Texas Pacific Northwest National Laboratory, June 2008 


\section{Appendix D: Analysis of Ground Source Heat Pump Opportunities}

\section{Ground Source Heat Pump Technology}

Ground source heat pumps (GSHPs) use the stable temperatures of the Earth and groundwater to improve the coefficient of performance of heating and cooling applications for buildings. Common GSHP configurations include open-loop, horizontal closed-loop, and vertical closed-loop systems.

$\checkmark$ Open-loop systems use open wells or bodies of water as direct heat transfer mediums to provide cool temperatures in the summer and warm temperatures in the winter. Heat transfer is only needed once, at the building, because groundwater is used directly, and the limited drilling and trenching needed results in a lower first cost.

$\checkmark$ Closed-loop systems use heat transfer fluid inside a sealed pipe to exchange heat with the earth. Closed-loop systems have lower pumping requirements and are more efficient than open-loop systems. However, soil type and moisture content is more critical to the performance of these systems, and the trenching and drilling significantly increases first cost. Horizontal loops require trenching, so that all the piping lies at the same depth in the ground.

$\checkmark$ Vertical closed-loop GSHPs are deployed in vertical boreholes, and are the most efficient configuration.

GSHPs are applicable in almost any building with both heating and cooling. They can be used in buildings as small as 100 square feet, or up to a million square feet. Multiple GSHPs can be used in a single building to meet the load. The same ground loop can be shared across multiple buildings.

Ground source heat pumps require certain local soil and/or water characteristics that depend upon the GSHP configuration. Open-loop GSHPs need a water source and sink. The source can be a well or open body of water. The sink can be a secondary well, the source body of water, another body of water, or a storm drain. Water volume requirements depend on the size of GSHP installed, but typically between 1.5 and 3.0 gallons per minute are needed per cooling ton. Concerns surrounding the use and disposal of water may eliminate many projects, as environmental managers often will not risk groundwater contamination (with reinjection) or depletion (with storm drain disposal).

Horizontal closed-loop GSHPs have a different limiting factor-adequate land area for deployment of heat transfer pipes. The heat transfer for these systems occurs in pipes laid in trenches that are 100 to 400 feet long per cooling ton, spaced 6 to 12 feet apart. The soil characteristics and number of pipes per trench determine the trench length; more pipes (up to six) per trench save land space but require more piping.

Where significant land area or water volumes are not available, vertical closed-loop GSHPs will be the only GSHP option. In these systems the heat transfer pipes are placed vertically in the ground, at depths of between 75 and 300 feet. Some land area is still required, as the pipe wells need to be spaced at least 15 to 20 feet apart. About 200 to 600 feet of pipe are needed per cooling ton. 


\section{Ground Source Heat Pump Analysis Approach}

In this assessment, GSHPs were evaluated using the 2008 Facility Energy Decision System (FEDS) analysis data for Fort Hood (part of the Energy Engineering Analysis Program, or EEAP, assessment). Open-loop, horizontal closed-loop, and vertical closed-loop configurations were analyzed for all buildings.

The FEDS building energy model (see Appendix A) was used to develop a representation of Fort Hood using data collected in a March 2008 site audit. Building data were entered for groups of similar buildings, based on age, size, and use type (see Table D-1). The model was run with current fuel prices and local technology and labor prices to determine GHSP economics across the site. Site-specific TMY (typical meteorological year) weather data and soil/ground characteristics were used in the analysis.

Table D.1: Building Groups Analyzed in FEDS for GSHPs

\begin{tabular}{|c|c|c|c|c|c|}
\hline \multirow[b]{2}{*}{$\begin{array}{c}\text { Group } \\
\text { ID }\end{array}$} & \multicolumn{4}{|c|}{ Building Group Description } & \multirow[b]{2}{*}{ Example Building(s) } \\
\hline & Use Type & $\begin{array}{l}\text { Average } \\
\text { Size (sf) }\end{array}$ & $\begin{array}{l}\text { Average } \\
\text { Vintage }\end{array}$ & $\begin{array}{l}\text { Number of } \\
\text { Buildings } \\
\text { Represented }\end{array}$ & \\
\hline 1 & Access Control Facilities & 325 & 1995 & 123 & 4504 \\
\hline 2 & Observation Towers & 300 & 1999 & 44 & 56246 \\
\hline 3 & Administration & 3,020 & 2006 & 63 & 340 \\
\hline 4 & Administration & 40,906 & 2007 & 2 & 10053,33050 \\
\hline 5 & Administration & 41,853 & 2006 & 9 & 43020 \\
\hline 6 & Administration & 316,996 & 1989 & 1 & 1001 \\
\hline 7 & Administration & 130,355 & 1984 & 2 & 410,28000 \\
\hline 8 & Administration & 191,496 & 2001 & 1 & 33009 \\
\hline 9 & Administration & 5,261 & 1942 & 62 & 4419 \\
\hline 10 & Administration & 6,265 & 1964 & 71 & 12001, 91044 \\
\hline 11 & Administration & 29,720 & 1963 & 8 & 4612 \\
\hline 12 & Administration & 5,272 & 1976 & 68 & 29013 \\
\hline 13 & Administration & 21,490 & 1976 & 23 & 39042 \\
\hline 14 & Administration & 3,919 & 1999 & 108 & 91230 \\
\hline 15 & Administration & 15,965 & 1994 & 31 & 14010 \\
\hline 16 & Fire Stations & 10,699 & 1999 & 8 & 52940 \\
\hline 17 & Police Stations & 7,410 & 1991 & 5 & 23020 \\
\hline 18 & Clinics & 10,757 & 1988 & 33 & 33003 \\
\hline
\end{tabular}


Table D.1: Building Groups Analyzed in FEDS for GSHPs (continued)

\begin{tabular}{|c|c|c|c|c|c|}
\hline 19 & Hospital & 553,838 & 1966 & 1 & 36000 \\
\hline 20 & Barracks & 40,053 & 1953 & 14 & 10007 \\
\hline 21 & Barracks & 41,907 & 1967 & 9 & 16003 \\
\hline 22 & Barracks & 42,193 & 1956 & 10 & 10010 \\
\hline 23 & Barracks & 46,538 & 1966 & 11 & 21006 \\
\hline 24 & Barracks & 51,479 & 1958 & 8 & 9210 \\
\hline 25 & Barracks & 143,293 & 1972 & 5 & 34006 \\
\hline 26 & Barracks & 4,209 & 1979 & 59 & 56430,56433 \\
\hline 27 & Barracks & 31,698 & 1977 & 18 & 39006 \\
\hline 28 & Barracks & 26,532 & 1968 & 10 & 5786,87013 \\
\hline 29 & Barracks & 42,278 & 1975 & 12 & 29008,87020 \\
\hline 30 & Barracks & 174,395 & 1999 & 2 & 91210,91220 \\
\hline 31 & Barracks & 168,223 & 2006 & 3 & 18015 \\
\hline 32 & Barracks & 1,560 & 2006 & 76 & 360 \\
\hline 33 & Dining & 5,371 & 1984 & 60 & 56425,34008 \\
\hline 34 & Exchange & 14,219 & 1984 & 22 & 85001 \\
\hline 35 & $\mathrm{PX}$ & 307,330 & 1977 & 1 & 50004 \\
\hline 36 & Laundry & 1,380 & 1997 & 10 & 3535 \\
\hline 37 & Storage - Range Facilities & 2,107 & 1995 & 60 & 56251 \\
\hline 38 & Hazmat Storage & 816 & 1987 & 126 & 26014 \\
\hline 39 & Weapons Storage & 2,038 & 1969 & 139 & 92196 \\
\hline 40 & Storage & 8,204 & 1943 & 47 & 4237 \\
\hline 41 & Storage & 3,420 & 1973 & 105 & 4660 \\
\hline 42 & Storage & 10,572 & 1998 & 68 & 19036 \\
\hline 43 & Storage & 264,496 & 1991 & 1 & 89010 \\
\hline 44 & Hangar & 39,417 & 1978 & 20 & 7007 \\
\hline 45 & Maintenance Shops & 2,558 & 1971 & 146 & 91059 \\
\hline 46 & Maintenance Shops & 4,330 & 1997 & 68 & 26007 \\
\hline 47 & Maintenance Shops & 99,550 & 1992 & 4 & 88036 \\
\hline
\end{tabular}


Table D.1: Building Groups Analyzed in FEDS for GSHPs (continued)

\begin{tabular}{||r|r|c|c|c|c||}
\hline 48 & $\begin{array}{r}\text { Vehicle Maintenance } \\
\text { Shops }\end{array}$ & 14,828 & 1961 & 49 & 15011 \\
\hline 49 & Vehicle Maintenance & 17,755 & 1980 & 45 & 9553 \\
\hline 50 & $\begin{array}{r}\text { Shops } \\
\text { Vehicle Maintenance } \\
\text { Shops }\end{array}$ & 15,535 & 1998 & 49 & 13100 \\
\hline 51 & Simulators & 16,851 & 1987 & 20 & 7050,22027 \\
\hline 52 & Electronics & 3,180 & 1980 & 65 & 13 \\
\hline 53 & Restrooms, Fitness \\
Centers & 2,599 & 1971 & 126 & 31006 \\
\hline 54 & MWR & 8,079 & 1980 & 68 & 24008 \\
\hline
\end{tabular}

In this assessment, FEDS was used to determine the most cost-effective GSHP configurations for each building type. These results provide a reliable first indication as to whether GSHPs might be economically feasible, and narrow the range of possibilities for potential projects, generating a list of building types that are worthwhile to investigate further.

These results do not provide an adequate basis for initiating a project. Additional site-specific data are required to narrow the options further and to provide a basis for project design. For instance, the model does not consider site limitations like land area or water source availability. The model assumes that there are sufficient thermal sources and sinks available. A thorough evaluation of land/water availability and soil characteristics is necessary before the system can be designed and actual costs can be determined. Soil characteristics can change across the same site, so findings at one location may not be universal across the post.

\section{Ground Source Heat Pump Resource Characterization}

GSHP assessments using FEDS have been completed at many DoD sites in the past using the same analytic approach. The results developed here agree with previous findings. In general, conditions favoring replacement of existing heating and cooling systems with GSHPs include:

$\checkmark$ Replacing old equipment. Equipment at the end of its useful life that will soon be replaced provides further economic incentive for GSHP installations, particularly if existing ductwork can be reused.

$\checkmark$ More extreme climates. Cold winters, hot summers, or large daily temperature swings allow GSHPs to operate more efficiently than other electric cooling and heating systems. The cost of heating operation is comparable to non-electric heating systems.

$\checkmark$ High cost of non-electric fuels. If electricity is less than approximately 3.5 times as expensive per Btu than other fuels, GSHPs will generally be cost effective. If no other fuel option is available and electric costs are high, GSHPs will be less expensive to operate than air-source heat pumps. 
GSHPs are often not cost effective in a building that:

$\checkmark$ Does not have both cooling and heating. A building needs to be both heated and cooled to take advantage of the GSHP efficiency in both modes.

$\checkmark \quad$ Is located in a mild climate. Buildings in fairly mild climates don't have the temperature extremes that make the ground loop important. A standard air-source heat pump would probably suffice.

$\checkmark$ Uses an air-source heat pump. An air-source heat pump has many of the benefits of a GSHP except in extreme temperature conditions. These extreme temperature conditions often aren't enough to justify replacement.

$\checkmark$ Does not currently have ductwork. Installing an entirely new air distribution system in addition to the conditioning equipment generally adds too much cost for a GSHP retrofit, unless individual GSHP units are installed in each room in a barracks, for instance.

$\checkmark \quad$ Is newer. Newer buildings (less than about 4 years old) generally have fairly efficient equipment (or at least the performance has not yet degraded significantly). As a result, premature replacement with a GSHP is generally uneconomic. In addition, the building envelope tends to be better, lengthening payback duration.

$\checkmark \quad$ Is connected to a central energy plant (unless the CEP will be abandoned). Although we often consider central energy systems as big energy wasters, on a building-by-building basis (which doesn't account for distribution losses) it's difficult to justify replacement. Centralized chiller plants can use larger, more efficient water-cooled units and can stage several chillers to run closer to full load (most efficient mode).

\section{Ground Source Heat Pump: Economic and Other Analysis Parameters}

FEDS allows two primary financing options: appropriated funding (ECIP) and alternative financing (UESC/ESPC). The parameters for alternative financing can be adjusted to match the options available to the site. For this assessment, a project life of 25 years and a third-party interest rate of $5 \%$ were used.

We used the site electric rate schedule and energy costs to determine fuel costs and savings for GSHP retrofits. The entire rate schedule is used so that consumption and demand can be calculated on a timeof-use basis. At Fort Hood, electricity is priced at $7.9667 \$ / \mathrm{kWh}$ with a $\$ 5.3077 / \mathrm{kW}$ demand charge. Natural gas costs $\$ 9.54 / \mathrm{MMBtu}$, based on historical and future trends according to NIST.

The estimated installed costs of open-loop GSHPs for the buildings found to be cost effective are shown in Table D-2. The difference in costs reflects differences in technology, and economies of scale working in favor of larger buildings. Where fewer or smaller units are being installed, the unit price increases. 
Table D.2: Average Installed Costs for GSHPs

\begin{tabular}{|c|c|c|c|c|c|}
\hline & & \multicolumn{4}{|c|}{ Appropriated Funding } \\
\hline \multicolumn{2}{|c|}{ GSHP Type } & Cost per & Avg Units & Cost per & Avg kBtu/hr \\
\hline Open Loop & $\begin{array}{c}\text { High } \\
\text { Efficiency }\end{array}$ & $\$ 6,818$ & 158.5 & $\$ 112.46$ & 0.38 \\
\hline $\begin{array}{l}\text { Horizontal Closed } \\
\text { Loop }\end{array}$ & $\begin{array}{c}\text { High } \\
\text { Efficiency }\end{array}$ & $\$ 7,103$ & 2 & $\$ 174.56$ & 20.35 \\
\hline
\end{tabular}

\section{Findings: Ground Source Heat Pumps}

As stated above, we evaluated all GSHP opportunities using both alternative financing and appropriated funding mechanisms. No cost-effective projects were identified for alternative financing scenarios. All project results described below are based upon appropriated funding mechanisms (e.g., ECIP).

The FEDS findings are provided below, organized by heating and cooling equipment types that are replaced. All of the combinations of existing heating and cooling systems analyzed are laid out in Table D-3 column and row headings, although only a few are applicable at Fort Hood. Empty cells indicate GSHPs are not cost effective for any building with those characteristics. Other cells show the number of the building group for which the technology combination was found to be cost effective. Table D-1 defines the building characteristics pertaining to the cost-effective options. The intent of Table D-3 is to show the economic technology combinations. Detailed results in Tables D-4 through D-5 show which building types, sizes, and vintages contain each of these replaceable equipment combinations, and which types of GSHP can economically replace the existing equipment.

Note that the buildings within each group do not all have the same heating and cooling technologies. Therefore when reviewing the results, note that if group 37 is said to be cost effective with an electric furnace and package AC unit, only the buildings in group 37 that currently use those technologies have been found to be cost effective. To that end, the average building characteristics listed in Table D-1 may not exactly represent the cost-effective buildings. 
Table D.3: Economic Evaluation of GSHP Opportunities at Fort Hood Empty cells identify HVAC combinations where no cost-effective retrofits were found

\begin{tabular}{|c|c|c|c|c|c|c|c|}
\hline & $\begin{array}{c}\text { Chiller / Air } \\
\text { Handling } \\
\text { Unit }\end{array}$ & $\begin{array}{c}\text { Chiller / } \\
\text { Fan Coil } \\
\text { Unit }\end{array}$ & $\begin{array}{c}\text { Chilled Water / } \\
\text { Air Handling } \\
\text { Unit }\end{array}$ & $\begin{array}{c}\text { Chilled } \\
\text { Water / Fan } \\
\text { Coil Unit }\end{array}$ & $\begin{array}{c}\text { Package } \\
\text { DX } \\
\text { Units }\end{array}$ & $\begin{array}{c}\text { Window } \\
\text { / Wall } \\
\text { Units }\end{array}$ & $\begin{array}{c}\text { Air- } \\
\text { Source } \\
\text { Heat } \\
\text { Pump } \\
\end{array}$ \\
\hline $\begin{array}{l}\text { Gas Boiler / Air } \\
\text { Handling Unit }\end{array}$ & 6,35 & & & & & & \\
\hline $\begin{array}{l}\text { Gas Boiler / } \\
\text { Fan Coil Unit }\end{array}$ & & & & & & & \\
\hline $\begin{array}{l}\text { Gas Boiler / } \\
\text { Radiator }\end{array}$ & & & & & & & \\
\hline $\begin{array}{l}\text { Hot Water / Air } \\
\text { Handling Unit }\end{array}$ & & & 14 & & & & \\
\hline $\begin{array}{l}\text { Hot Water / } \\
\text { Fan Coil Unit }\end{array}$ & & & & & & & \\
\hline $\begin{array}{l}\text { Hot Water / } \\
\text { Radiator }\end{array}$ & & & & & & & \\
\hline $\begin{array}{l}\text { Electric } \\
\text { Furnace } \\
\end{array}$ & & & & & 37 & & \\
\hline Gas Furnace & & & & & & & \\
\hline $\begin{array}{l}\text { Electric } \\
\text { Baseboard }\end{array}$ & & & & & & & \\
\hline $\begin{array}{l}\text { Air Source } \\
\text { Heat Pump }\end{array}$ & & & & & & & \\
\hline
\end{tabular}

As expected, retrofit of many heating/cooling combinations is not cost effective for any building. Airsource heat pumps and technologies without ductwork (i.e., fan coil units, window AC units) cannot economically be replaced with GSHPs, regardless of the building type, size, or vintage. Chillers and boilers with air handling units tend to be the most cost-effective technology combination.

Tables D-4 and D-5 show the cost-effective GSHP options and their respective simple paybacks. Simple paybacks are noted in brackets. Only two buildings were found to be cost effective for openloop GSHP retrofits (Table D-4) at Fort Hood - two large buildings, an administrative building (Building 1001) and the PX (Building 50004).

The following phrases are used below to describe the cost-effective ground source heat pump technologies.

$\checkmark$ High efficiency, open-loop: coefficient of performance (COP) $=4.2$ for heating; $\mathrm{COP}=4.4$ for cooling

$\checkmark$ High efficiency, closed-loop: $\mathrm{COP}=4.3-4.4$ for heating; $\mathrm{COP}=4.4$ for cooling 
Table D.4: Cost-Effective Open-Loop GSHPs with Appropriated Funding

\begin{tabular}{|c||c||}
\hline \hline HEATING/COOLING TECHNOLOGY & Chiller with Air Handling Unit \\
\hline \hline $\begin{array}{c}\text { Gas Boiler with } \\
\text { Air Handling Unit }\end{array}$ & $\begin{array}{l}\text { Admin; 316,996sf; 1989 - high efficiency [7.1 yrs] } \\
\text { PX; 307,330sf; 1977 - high efficiency [6.3 yrs] }\end{array}$ \\
\hline
\end{tabular}

Table D.5: Cost-Effective Closed-Loop GSHPs with Appropriated Funding

\begin{tabular}{||c||c|c||}
\hline & $\begin{array}{c}\text { Chilled Water with } \\
\text { Air Handling Unit }\end{array}$ & Package DX Units \\
\hline \hline $\begin{array}{c}\text { Hot Water with } \\
\text { Air Handling Unit }\end{array}$ & $\begin{array}{l}\text { Admin; 3,919sf; 1999 - horizontal } \\
\text { high efficiency [*] }\end{array}$ & \\
\hline Electric Furnace & & $\begin{array}{l}\text { Range Facilities; 2,107sf; 1995 - } \\
\text { horizontal high efficiency [12.4 yrs] }\end{array}$ \\
\hline \hline
\end{tabular}

*All retrofits from central heating and cooling are cost effective only if the CEP loop is abandoned.

With closed-loop GSHPs, only buildings using electric heating and cooling, and projects gaining savings from abandoned distribution lines were found to be cost effective. These buildings are listed in Table D-6.

Table D.6: Fort Hood Buildings with the Potential for Cost-Effective GSHP Retrofit

\begin{tabular}{|c|c|c|c|c|c|c|c|c|}
\hline 91230 & 56004 & 56152 & 56184 & 56206 & 56231 & 56250 & 56275 & 56285 \\
\hline 91231 & 56006 & 56161 & 56187 & 56212 & 56233 & 56251 & 56276 & 56286 \\
\hline 91232 & 56007 & 56173 & 56190 & 56214 & 56235 & 56255 & 56277 & 56290 \\
\hline 91233 & 56117 & 56174 & 56192 & 56215 & 56237 & 56257 & 56278 & \\
\hline 91234 & 56118 & 56177 & 56197 & 56223 & 56240 & 56266 & 56279 & \\
\hline 91235 & 56120 & 56179 & 56200 & 56225 & 56244 & 56267 & 56281 & \\
\hline 91236 & 56126 & 56180 & 56202 & 56227 & 56245 & 56270 & 56282 & \\
\hline 91237 & 56143 & 56181 & 56203 & 56230 & 56248 & 56271 & 56284 & \\
\hline
\end{tabular}

If retrofits are realized in all 69 of these buildings, then about 20,924 MMBtus could be saved per year. The maximum electric load of this equipment, based on rated size, would be about 6.7 MW.

\section{Ground Source Heat Pumps: Next steps}

Fort Hood needs to determine whether water for open-loop systems is available, and if so, if it is environmentally acceptable to use it for GSHP development. For closed-loop projects, land area information should be collected for cost-effective buildings to determine horizontal closed-loop GSHP feasibility. For all projects determined to have the requisite site characteristics, project design by an experienced designer can then be pursued.

\section{Ground Source Heat Pump References}

Federal Technology Alert. "Ground Source Heat Pumps Applied to Federal Facilities - Second Edition.” Federal Energy Management Program. DOE/EE-0245. March 2001. 
APPENDIX E

\section{Analysis of Solar Opportunities}

Renewable Energy Opportunities at Fort Hood, Texas Pacific Northwest National Laboratory, June 2008 
Renewable Energy Opportunities at Fort Hood, Texas Pacific Northwest National Laboratory, June 2008 


\section{Appendix E: Analysis of Solar Opportunities}

\section{Solar Technologies}

There is a wide range of solar technologies and applications. Solar technologies can be classified by the specific method for converting solar energy into useful energy for direct use as a substitute for a conventional energy source. Solar energy is unique in that the sun's energy can be captured to provide electrical energy, heating energy (solar thermal), or a combination of both. Solar electric collectors are either photovoltaic (PV) arrays or concentrating solar arrays. There are three major PV array subcategories, as follows:

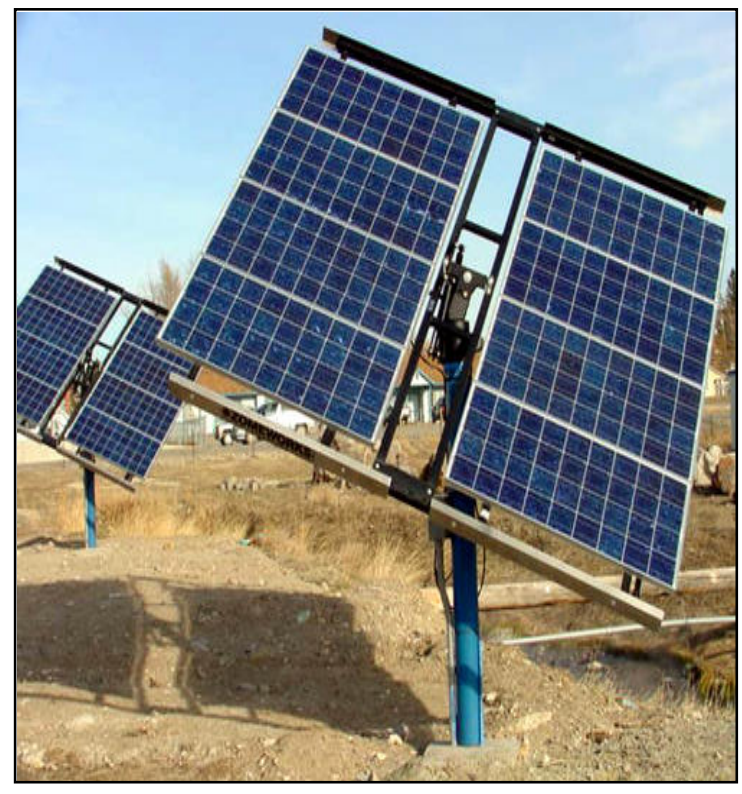

Figure E.1: Axis tracking PV array

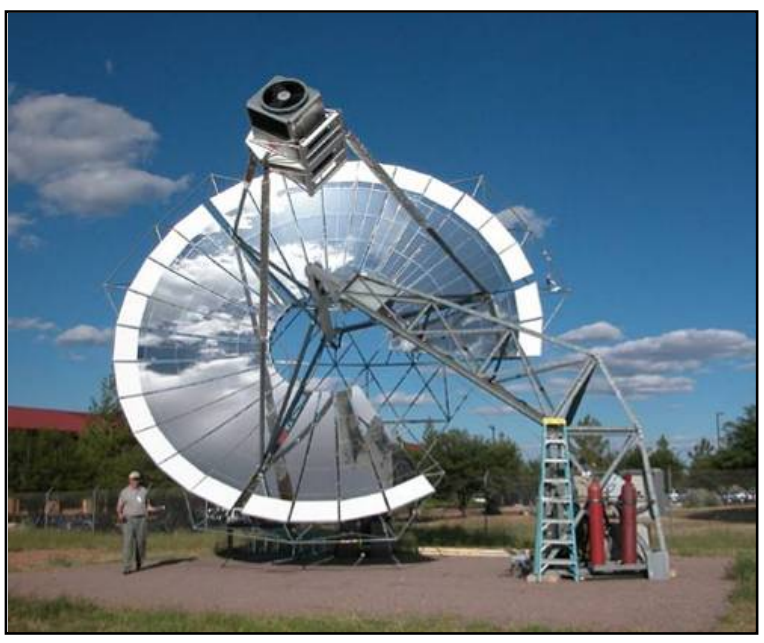

Figure E-3: Fort Huachuca Stirling solar engine
* Flat Panel. Arrays of PV modules mounted on racks either at ground level or on rooftops at a fixed angle - generally this angle is equal to the location latitude.

* Axis Tracking. PV arrays mounted on an assembly that moves throughout the day keeping the array pointed directly at optimum angle to capture sunlight (Figure E-1).

* Integrated PV Products. PV is available integrated with building materials which provides a cleaner look than stand-alone panels. PV comes as replacements for standard three-tab shingles, metal standing-seam roofing, and membrane roofing for flat roofs (Figure E-2).

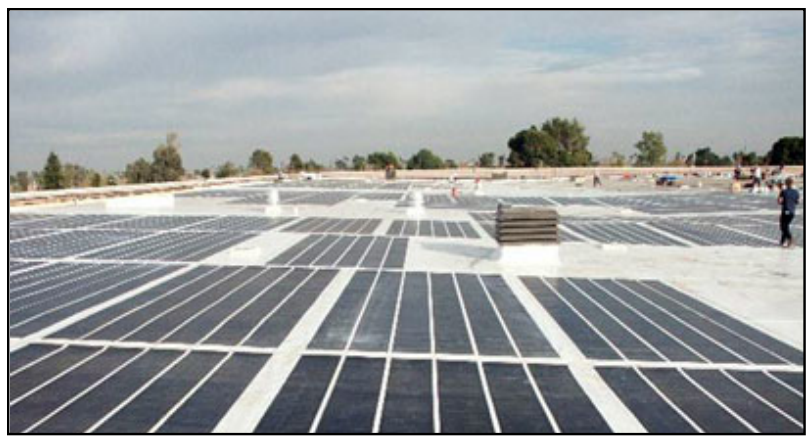

Figure E-2: Integrated PV on Base

Concentrating solar power (CSP) systems use mirrors to concentrate the sun's energy on a central receiver, delivering higher temperatures for power production. There are three primary configurations for CSP as follows:

* Stirling Engine. A stirling engine is a mechanical device that when heated by the sun uses expanding and contracting gases to drive a piston that produces energy (Figure E-3). 
* Central tower. Very large arrays of mirrors concentrate the sun's energy on a central receiver tower to produce steam to drive a generator.

* Solar Trough. When used for power generation these very large arrays concentrate the sun's energy on a pipe containing a liquid which in turn is used to generate steam to drive a generator.

Rather than electricity as the end product, solar energy can be used to heat air directly, heat water that is used for space heating, or heat water that is directly used for service hot water (SHW) or swimming pools. Solar thermal collectors can take many forms, including:

* Transpired solar collector. These collectors sometimes called solar walls - preheat incoming air to a building by drawing intake air through perforated panels installed on the southern exposure of buildings (Figure E-4).

* Solar Trough. Similar in design to troughs used to generate power, but smaller in scope, solar troughs can be used to heat/pre-heat water for hydronic systems.

* Flat-plate collector. Glazed flat-plate collectors are insulated, weatherproofed boxes that contain a dark absorber plate under one or more glass or plastic (polymer) covers.

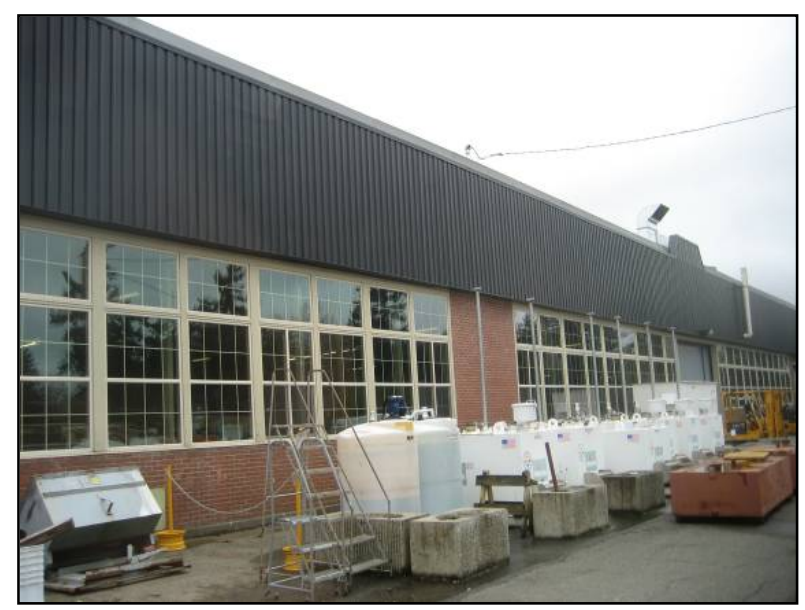

Figure E-4: Solar wall installed at Fort Lewis

* Evacuated-tube solar collector. They feature parallel rows of transparent glass tubes. Each tube contains a glass outer tube and metal absorber tube attached to a fin. The fin's coating absorbs solar energy but inhibits radiative heat loss.

Finally, daylighting fixtures are becoming important. Modern version of traditional skylights have better insulating properties and light dispersion. Some are integrated into a standard 2x4 foot fluorescent fixture. Light shelves, atriums, and solar tubes are examples of daylighting fixtures (Figure E-5).

Solar technologies can be further categorized by their scale. Large-scale solar projects can be massive in scope with hundreds of collectors and solar energy output expressed in hundreds of kilowatts of energy. Smaller-scale projects, often called building-integrated, are also possible and may be more desirable because of space limitations, for aesthetics, or other reasons. Certain solar technologies, like photovoltaic, can

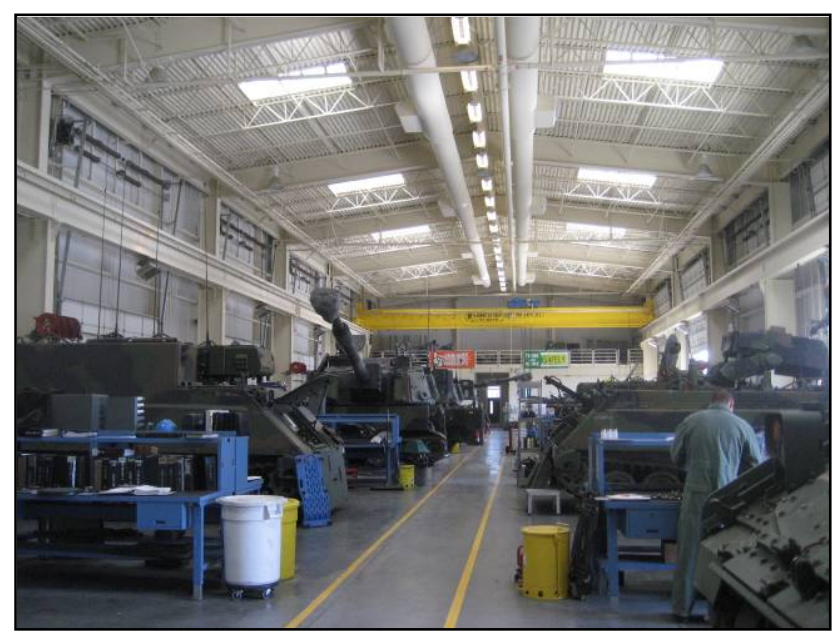

Figure E.5: Daylighting fixtures at the Yakima Training Center 
be either large-scale or small-scale, while technologies like solar walls are only found at the building level.

\section{Solar Analysis Approach}

A 2003 DOD report looking for solar energy applications on military bases selected Fort Hood as one of only 33 installations out of the 500 sites screened for further evaluation. Only solar thermal for swimming pool heating was selected for additional analysis, although daylighting, solar hot water, and transpired solar collectors were estimated to be cost effective with a 6 to 9 year simple payback. Although the cost data in the 2003 report are out-dated, the results do not disagree with current analysis.

This analysis was restricted to solar-electric technologies. The analytic approach for the solar energy assessment consists of the following steps:

(1) Characterize the solar resource-Determine seasonal and annual solar radiation from existing sources

(2) Understand the utility environment—Obtain electric rate tariff information, evaluate state and local regulations, and identify grants, incentives, and other support.

(3) Determine applicable solar technology_-Identify and evaluate potential large-scale and smallscale solar electric technologies.

(4) Identify Potential Development Areas-Identify installation-specific sites and potential users of generated energy for both on- and off-site uses. Study existing electrical transmission system for potential siting opportunities.

(5) Establish project economics-Determine project capital investment cost, project operations \& maintenance costs, and estimate economic value of expected electric production based on selected solar technology and market prices.

\section{Solar Resource Characterization}

Resource potential was estimated using the solar potential estimates in the National Aeronautics and Space Administration (NASA) report, Surface meteorology and Solar Energy (SSE). The SSE data set is a continuous and consistent 10 -year global climatology of insolation and meteorology data on a $1^{\circ}$ by $1^{\circ}$ grid system. The SSE data within a particular grid cell are not necessarily representative of a particular microclimate (or point within the cell), as the data are considered to be the average over the entire area of the cell. However, these data are accurate enough for preliminary feasibility studies of new renewable energy projects. In addition, SSE provides year-to-year variability in terms of 10 -year maximums and minimums for a number of parameters.

For each site, the average solar insolation is shown for three different types of surfaces: flat roof surface, a flat panel with a tilt equal to the latitude, and a flat wall mounted panel. Average monthly insolation is given in $\mathrm{kWh} / \mathrm{m}^{2}$-day for the following conditions:

$\checkmark$ Tilt 0 - Collectors install flat (i.e., on a flat roof surface)

$\checkmark$ Tilt (lat-15) - A tilt of latitude minus 15 degrees would favor energy production in the summer when the sun is higher

$\checkmark$ Tilt lat - Tilting a PV array at an angle equal to the latitude is a generally accepted way to optimize electricity production 
$\checkmark$ Tilt (lat+15) - A tilt of latitude plus 15 degrees would favor energy production in the winter when the sun is lower

$\checkmark$ Tilt 90 - Collector installed against a vertical surface (i.e., wall)

$\checkmark$ OPT Tilt - If a collector were tilted at the optimum tilt angle for each month this would be electricity production

$\checkmark$ OPT ANG - This is the optimum tilt angle for each month of the year.

\section{Solar Resource}

The solar resource data shows that a flat collector tilted at $31^{\circ}$ has an average yearly solar potential of $5.18 \mathrm{kWh} / \mathrm{m}^{2} /$ day for Fort Hood (see table E.1). A PV array set to the optimum angle each month will receive $5.44 \mathrm{kWh} / \mathrm{m}^{2} /$ day incident solar radiation.

Table E.1: Monthly Averaged Radiation Incident On An Equator-Pointed Tilted Surface (kWh/m²/day)

\begin{tabular}{|l|c|c|c|c|c|c|c|c|c|c|c|c|c|}
\hline & & & & & & & & & & & & Annual \\
& Jan & Feb & Mar & Apr & May & Jun & Jul & Aug & Sep & Oct & Nov & Dec & Average \\
\hline Tilt 0 & 2.61 & 3.32 & 4.45 & 5.38 & 5.67 & 6.36 & 6.54 & 5.85 & 4.92 & 4.06 & 2.96 & 2.34 & 4.54 \\
\hline Tilt 16 & 3.41 & 4.08 & 5.1 & 5.77 & 5.72 & 6.27 & 6.5 & 6.1 & 5.51 & 4.9 & 3.81 & 3.09 & 5.03 \\
\hline Tilt 31 & 3.96 & 4.55 & 5.4 & 5.79 & 5.42 & 5.8 & 6.07 & 5.96 & 5.74 & 5.39 & 4.38 & 3.61 & 5.18 \\
\hline Tilt 46 & 4.27 & 4.75 & 5.39 & 5.46 & 4.83 & 5 & 5.28 & 5.49 & 5.63 & 5.56 & 4.69 & 3.92 & 5.02 \\
\hline Tilt 90 & 3.71 & 3.76 & 3.61 & 2.81 & 2.03 & 1.8 & 1.94 & 2.6 & 3.51 & 4.22 & 3.98 & 3.47 & 3.12 \\
\hline OPT & 4.34 & 4.76 & 5.44 & 5.83 & 5.75 & 6.38 & 6.58 & 6.11 & 5.74 & 5.56 & 4.74 & 4 & 5.44 \\
\hline OPT ANG & 57 & 49 & 38 & 24 & 10 & 4 & 7 & 18 & 34 & 46 & 55 & 58 & 33.2 \\
\hline
\end{tabular}

Figure E-6 shows the incident solar radiation on a flat roof surface ( $0^{\circ}$ tilt), a fixed array (tilt=latitude), and a wall mounted system ( $90^{\circ}$ tilt). 


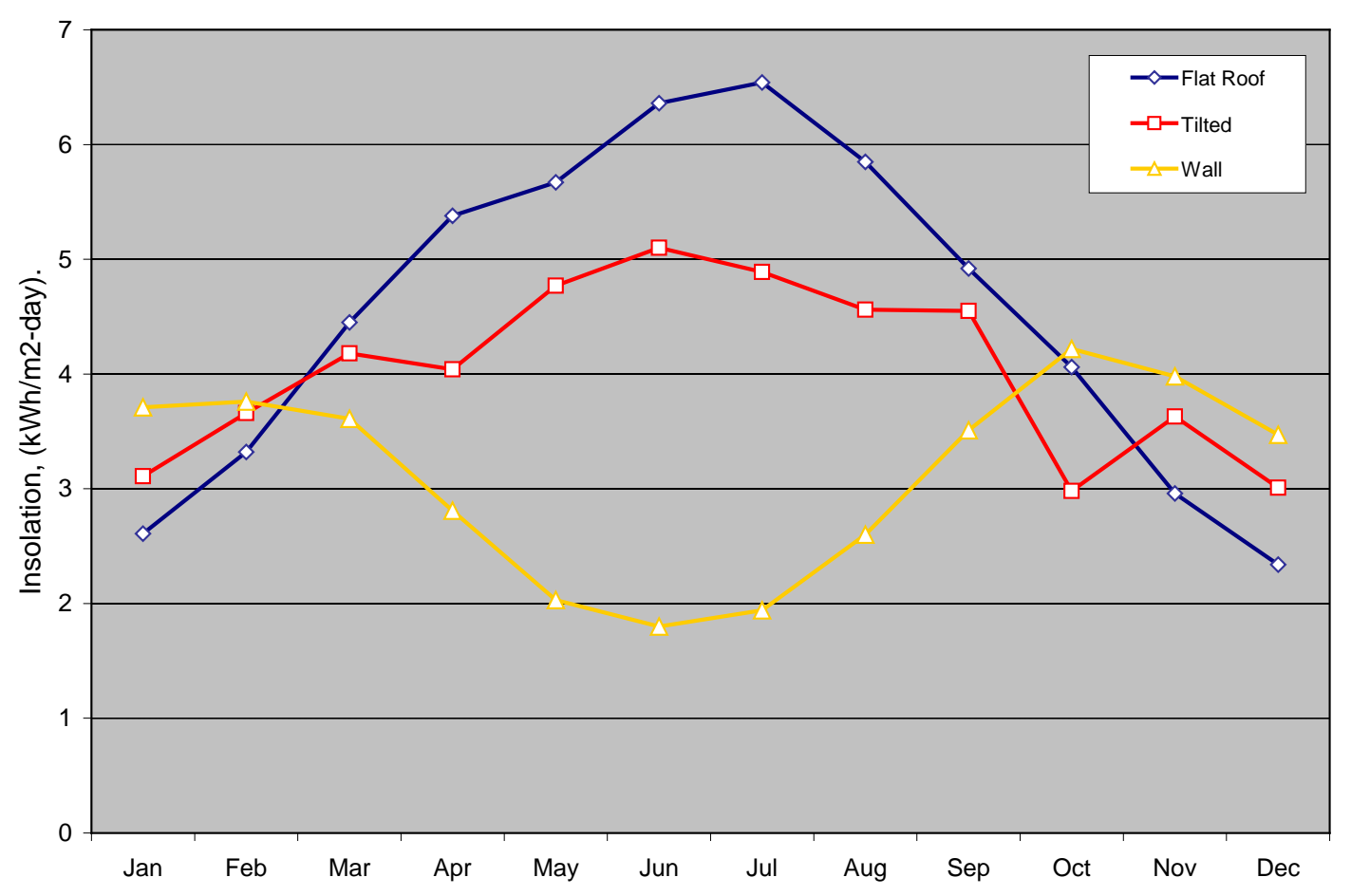

Figure E.6: Fort Hood Average Daily Solar Radiation 


\section{Solar Electric Production}

Based on the solar resource data, a flat collector tilted at an angle equal to the latitude $\left(31^{\circ}\right)$ has an average yearly solar potential of $5.18 \mathrm{kWh}_{\text {solar }} / \mathrm{m}^{2} /$ day. Solar conversion is an inefficient process, where typical PV cells have a conversion efficiency ranging from $10 \%$ to $16 \%$. Whereas solar potential is expressed in $\mathrm{kWh}_{\text {solar }} / \mathrm{m}^{2}$, PV array production is generally express as annual energy produced per rated $1 \mathrm{~kW}$ of PV array. A typical 1-kW PV array might range in size from 8 to $9 \mathrm{~m}^{2}$. Taking into account the annual solar potential, the size of typical PV array, and the efficiency of a typical PV system, electric output would be expected to produce 1,530 $\mathrm{kWh}_{\mathrm{e}}$ per $1 \mathrm{~kW}$ of installed PV capacity. The system would have a capacity factor of $17 \%$.

An axis-tracking PV array that follows the sun's trajectory throughout the day can produce $30 \%$ to $40 \%$ more energy than a stationary PV array and has a much flatter generation profile during the day. The tracking racks add to the cost of an installation by $\$ 1$ to $\$ 2$ per installed $\mathrm{kW}$. Because of this additional cost based on the size of array installed, tracking arrays will likely contain PV technologies with higher output per surface area in spite of the additional cost. An axis-tracking array should produce 2,007 $\mathrm{kWh}_{\mathrm{e}}$ annually per $1 \mathrm{~kW}$ of installed PV capacity. The system would have a capacity factor of $23 \%$.

Building-integrated solar products such as standing seam roofs and membrane embedded PV should be considered for new construction and major renovations where cost savings can be leveraged. For example, if a roof needs to be replaced, the replacement would be an avoided cost for the solar project. For example, a membrane-integrated PV product installed on a flat roof would be expected to produce $1,488 \mathrm{kWh}_{\mathrm{e}}$ annually per $1 \mathrm{~kW}$ of installed capacity. The system would have a capacity factor of $17 \%$.

Building integrated PV products would be especially attractive at Fort Hood where available land is constrained. Looking for applicable roof space using satellite imagery shows 149 buildings with 1.5 million square feet of roof area that could host PV arrays. Fort Hood could install $5.1 \mathrm{MW}_{\text {peak }}$ of roofintegrated PV, which would produce approximately 7,435 $\mathrm{MWh}_{\mathrm{e}}$ annually.

\section{Solar: Economic and Other Parameters}

Constellation Energy provides electricity to Fort Hood. The energy charges amount to $\sim 7.9 \$ / k W h$ with a total demand component that works out to $\sim 0.6 \$ / \mathrm{kWh}$. Based on these numbers life-cycle costs were developed for solar projects that could be implemented on Fort Hood using federal funding such as ECIP.

\section{Findings: Solar Energy}

The fixed-grid PV had a 0.3 SIR and a 55.4-year simple payback. In fact, to get a positive net-presentvalue the system would have to offset power costing $41 \$ / \mathrm{kWh}$. Even with carbon taxes and selling renewable energy credits this project would be extremely difficult to justify. The axis-tracking PV system did only slightly better (as a result of its better capacity factor) at 49.9 year simple payback producing power at $38 \mathrm{\$} / \mathrm{kWh}$. It is also important to note that a very large PV project could also incur large exit or stand-by charges from the serving utility to continue to maintain capacity when the solar project is not producing, making the projects even less cost effective.

A second mechanism to install solar projects would be to utilize a third party to develop the projects under a power purchase agreement (PPA) or other vehicle. Under a PPA a private company would develop, fund, and install the solar project. The third party, being a private company, could take 
advantage of tax credits for renewable energy projects and might also wish to sell the "green tags" for this renewable energy.

Fort Hood's electric provider, Constellation Energy, does not currently offer any incentives for renewable energy production.

\section{Solar Energy-Next Steps}

Based on the solar energy potential and current economic analysis, Fort Hood has no reasonable prospects for utility-scale economic PV energy projects. Smaller projects could, however, prove cost effective if they eliminate some capital costs necessary to deliver commercial power to a remote site.

\section{Solar Energy: References}

NASA Surface Meteorology and Solar Energy (release 5.1) [http://eosweb.larc.nasa.gov/sse/].

RETscreen International, Clean Energy Decision Support Centre, CANMET Energy Technology Centre - Varennes, Natural Resources Canada. (c) Minister of Natural Resources Canada 1997 - 2005.

“Global Concentrating Solar Power Markets and Strategies, 2007-2020” Emerging Energy Research, LTD, Cambridge, MA, November 2007.

TMY data from the Solar and Wind Energy Resource Assessment Programme, the International Weather for Energy Calculations (Version 1.1). 
Renewable Energy Opportunities at Fort Hood, Texas Pacific Northwest National Laboratory, June 2008

\section{E.8}


APPENDIX F

\section{Analysis of Wind Opportunities}

Renewable Energy Opportunities at Fort Hood, Texas Pacific Northwest National Laboratory, June 2008 
Renewable Energy Opportunities at Fort Hood, Texas Pacific Northwest National Laboratory, June 2008 


\section{Appendix F: Analysis of Wind Opportunities}

\section{Wind Technology}

There is a vast wind resource in the United States. The American Wind Energy Association states that domestic wind resources, which are economically viable in at least 46 states, could theoretically supply all of the nation's electricity needs. At the current time, however, less than $1 \%$ of the nation's power is generated from wind. This situation is changing. In 2005 and 2006, wind was the second largest source of new electricity generation in the United States.

Wind projects, often referred to as wind farms, can be categorized by scale. Large, utility-scale projects tend to be $50 \mathrm{MW}$ and above, with the world largest single wind farm being the 735-MW Horse Hollow Wind Energy Center in Texas. Smaller projects under $50 \mathrm{MW}$ are referred to as community wind projects or distributed generation projects. Community wind projects involve local ownership structures, often with corporate partners taking advantage of the Federal Production Tax Credit. Distributed generation (DG) projects are designed to offset the owner's retail electricity purchases by producing power that is used on site, with any surplus sold to a commercial utility.

Wind turbines come in many different sizes and configurations. Wind turbines in the U.S. generally employ the Danish configuration - a horizontal axis, three bladed rotor, an upwind orientation, and an active yaw system to keep the rotor oriented into the wind.

Utility-scale turbines for bulk power production tend to be $660 \mathrm{~kW}$ to $3 \mathrm{MW}$ in size. Hub heights can range from 50 meters (164 ft.) to 80 meters (262 ft.). Industrial turbines for consumer and remote grid production are found in the range of $50 \mathrm{~kW}$ to $250 \mathrm{~kW}$. Hub heights range between 25 meters (80 ft.) and 40 meters $(131 \mathrm{ft}$.). Residential scale wind turbines are used for remote power, battery charging, or net-metering generation. These turbines tend to be 400 watts to $50 \mathrm{~kW}$. For turbines greater than $1 \mathrm{~kW}$, the hub heights range from 12 meters ( $40 \mathrm{ft}$.) to 36 meters (120 ft.).

The land required for a single utility-scale wind turbine is typically 3 acres, including access roads, turbine base, and other equipment. A wind plant located on a ridgeline in hilly terrain will require less space than one on flat land, as little as two acres per megawatt. The proper spacing of turbines is essential to reduce wake interference and optimization of the wind resource. In open flat terrain, a utility-scale wind plant will require about 60 acres per megawatt of installed capacity.

Although more difficult to finance and lacking in economies of scale, smaller wind generation projects (including potential projects at Fort Hood) offer some potential benefits over large-scale wind farms:

$\checkmark$ A smaller project is often easier to permit and may be less likely to interfere with other land uses (including military missions).

$\checkmark$ On-site power generation that is integrated into the site electrical system provides energy security.

$\checkmark$ It may be possible to avoid building a costly substation if a suitably-sized power interconnection is located near a promising site for wind turbines. 


\section{Wind Analysis Approach}

\section{DoD Assessment Approach}

The DoD Renewables Study relied upon the National Renewable Energy Laboratory (NREL) wind potential maps to identify the installations with best potential for commercial-scale wind farmsconsidering both the wind resource and compatibility with the installation's mission. About 20 installations with potential for projects were selected for follow-on detailed assessments. Fort Hood was not on this list because of its low rank on the NREL wind resource potential map.

As part of the detailed study, the DoD funded the installation of a meteorological tower at selected sites for a 1-year wind resource assessment. Wind assessments were conducted by Global Energy Concepts (GEC) under a subcontract to NREL. Typically, GEC erected a meteorological tower and collected data for a year. These data were analyzed with other information from a site visit to develop a sample wind turbine siting plan appropriate for the site and resource, as well as an estimate of developmental costs. These data were then used for preliminary economic analyses under IPP and ECIP scenarios.

In general, projects at least $20 \mathrm{MW}$ in size and a 30\% capacity factor, with at least a 15\% IRR were considered to be attractive to potential financers. Smaller projects, and those with IRRs between 10\% and $15 \%$, were considered marginally financeable. Projects with payback periods less than 20 years and SIRs of at least 1.25 were considered to be eligible for ECIP funds.

\section{Updated Wind Analysis Approach}

In this analysis, PNNL used the following approach to analyze the economic potential for wind energy at Fort Hood. More detail on the financing scenarios, generic analytic approach, and economic and other parameters used in this analysis are documented in Appendix A of this report.

(1) We relied upon existing meteorological data (on site and near site) and wind maps, including the GEC-generated data set (if available).

(2) We evaluated the existing on-post interconnection and transmission capacity and its available capacity.

(3) We interviewed a local wind developer to assess potential interest in developing projects on DoD land.

(4) We evaluated available turbine models to establish cost and performance parameters.

(5) We estimated total project cost, including project development, generation equipment, balance of plant construction, interconnection and transmission, operation and maintenance, taxes, and tax credits and other policy incentives.

(6) We determined economic feasibility utilizing different financing scenarios: independent power producer ownership (IPP) and DoD ownership (ECIP).

(7) We determined project feasibility and recommended next steps. 


\section{Wind Resource Characterization}

There appears to be plenty of available land on Fort Hood with the potential for a low-to-medium quality wind resource. The best wind resource is typically available in areas with increased elevation. There are many hills within the boundaries of Fort Hood that could have potentially good wind. The installation of a meteorological tower and the gathering of wind data for a minimum of one year are necessary to determine the true viability of the wind resource on site. For this assessment, a wind farm size of approximately $140 \mathrm{MW}$ was assumed, since this was the size of a recent commercial wind proposal that had been evaluated by the Fort.

According to the Texas Wind Resource Map Bell County has Class 2 winds in the range of 12.5 to 4.3 mph $(5.60$ to $6.40 \mathrm{~m} / \mathrm{s})$. Wind projects in Texas tend to occur in areas with winds of Class 4 or better. The Texas Wind Resource Map is not very refined and has not been updated since it was generated in the 1980s.

NASA Langley Research Center Atmospheric Science Data Center was used to correlate the average wind speed for the Ft. Hood area. Using the Surface Meteorology and Solar Energy (SSE) data over a 10-year period from July 1983 to June 1993, the annual average wind speed was found to be $5.73 \mathrm{~m} / \mathrm{s}$ at 50 meters above the surface of the Earth. NASA SSE data also provides for wind speed predictions at greater heights with adjustment for surface level roughness. At 80 meters (hub height for a typical wind turbine), the wind speed is estimated to be $6.5 \mathrm{~m} / \mathrm{s}$. (NASA 2007). Even though this speed is higher, it is still well below the average wind speeds that wind project developers in Texas would typically target.

As a secondary source of wind speed potential, the Firstlook wind map from 3TIER was consulted. At 50-m height above ground, the potential average annual wind speed is estimated to reach a high of 5.8 $\mathrm{m} / \mathrm{s}$. At 80 meters, a speed of $6.3 \mathrm{~m} / \mathrm{s}$ is estimated as the highest on site potential average annual wind speed (3TIER 2008).

To achieve a more accurate predication of the wind potential, a careful review of the topography of the potential development sites would need to be conducted with the purpose of erecting one or more meteorological (met) towers for measuring wind speed, wind direction, and temperature. A minimum of one 50-meter met tower with 1 year of recorded wind data is needed to determine the actual potential for a wind project.

\section{Additional Siting Considerations}

Another siting consideration for wind projects is transmission availability and capacity. Projects need to be located within approximately 1 mile of existing transmission lines, or new lines will need to be constructed at considerable cost. See Figure F-1 below for the location of transmission lines on and near Fort Hood. There are several 138-kV transmission lines located near and across the southern boundary of the installation. This size line would potentially allow for a wind project greater than $100 \mathrm{MW}$. There are also 69-kV lines located near the North Fort Hood boundary. These lines could potentially accommodate up to $100 \mathrm{MW}$. An interconnection and transmission analysis would need to be conducted to determine the actual capacity available on these lines prior to moving forward with a wind project.

Another consideration that could affect the viability of wind generation at Fort Hood is potential interference with airport operations. Killeen-Fort Hood Regional Airport is located within the footprint 
of the installation. The FAA requires notice of proposed construction for a project so that it can determine if there would be adverse impacts to air navigation safety. One of the triggering criteria is whether the project would be located within 20,000 ft $(6,096 \mathrm{~m})$ or less of an existing public or military airport (Section 4.7.3). Another FAA criterion triggering the notice of proposed construction is any construction or alteration of more than $200 \mathrm{ft}(61 \mathrm{~m})$ in height above ground level. This criterion applies regardless of the distance from the proposed project to an airport. A determination of No Hazard to Air Navigation must be obtained from the FAA prior to constructing a wind project (FAA 2007). The potential development locations near the $138-\mathrm{kV}$ lines at Fort Hood are within the 6,096-m perimeter of Killeen-Fort Hood Regional Airport. Siting a project this close to the airport could prove difficult and it would require a determination of No Hazard to Air Navigation prior to moving forward with a wind project. Given the siting considerations, the targeted location for an on-site project may need to be the northern portion of Fort Hood to avoid potential conflict with the airport. If power from such a project were to be used by the installation, it would have to be wheeled from the northern edge of the site to the cantonment area using the transmission lines to the east of the post. The power could also be sold into the Texas power grid and wheeled to other customers.

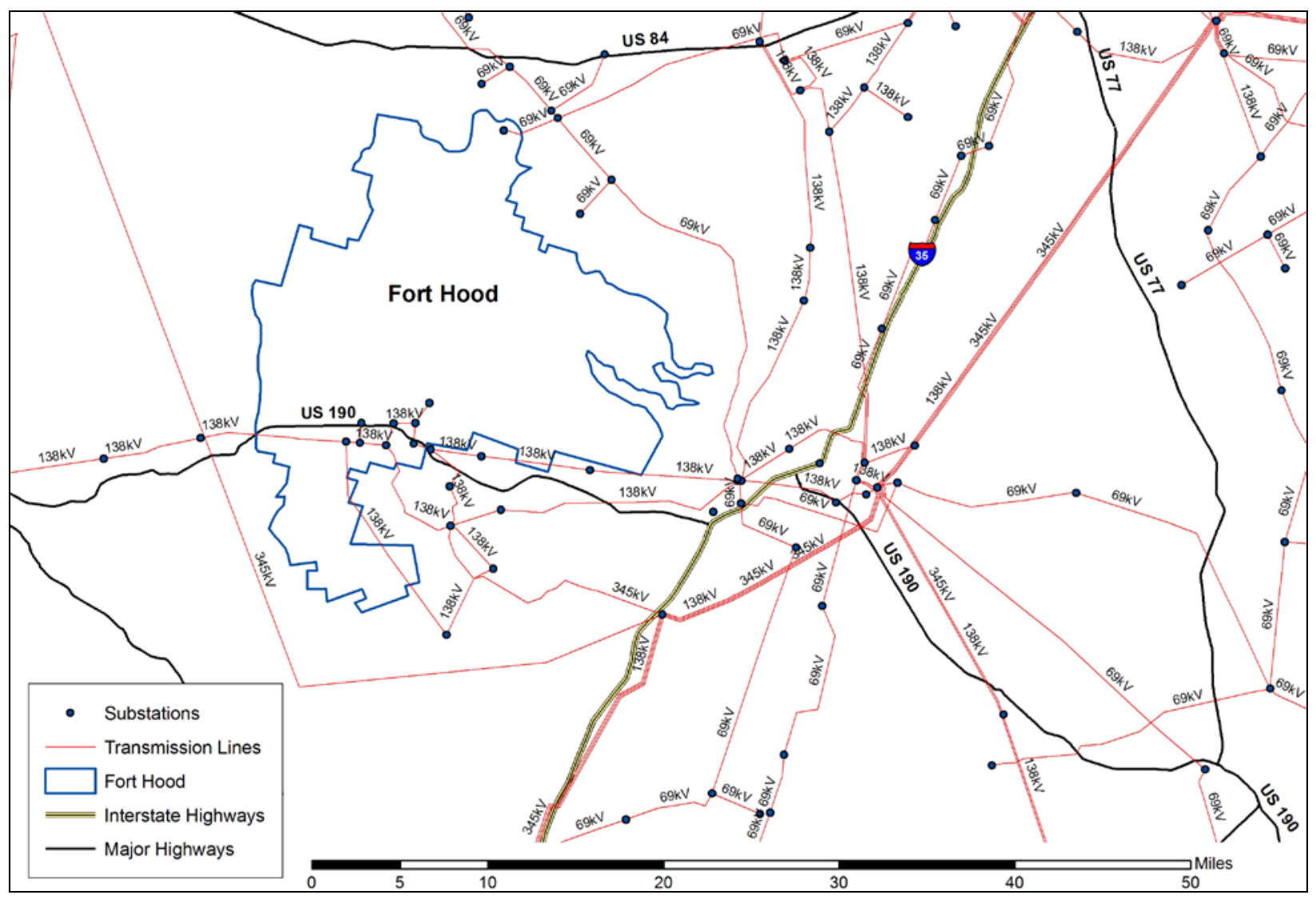

Figure F.1: Location of Transmission Lines in Relation to Fort Hood

A potential mission conflict was also identified by personnel at Fort Hood. There are building restrictions on some portions of Fort Hood because of low-flying helicopters. Further details are needed on the exact locations of these restricted areas and the range of impact on tall wind tower structures. This restriction could further limit the potential development areas. 
This assessment considered the current Federal wind incentive - a $2.0 \$ / \mathrm{kWh}$ renewable energy production credit, 5-year accelerated depreciation, and the Texas renewable energy income and property tax exemption. During the original DoD renewable energy assessment in 2005, the installed cost of capital was approximately $\$ 1,400 / \mathrm{kW}$; at the current time prices range from $\$ 1,900$ to $\$ 2,100 / \mathrm{kW}$ because of a world-wide turbine shortage and increased costs for components. The capital cost was assumed to be $\$ 1,965.50$ per $\mathrm{kW}$ for this economic assessment.

For the economic analysis, the wind speed was assumed to be $6.5 \mathrm{~m} / \mathrm{s}$ at an 80 -meter hub height, yielding a capacity factor of $29 \%$. Fixed O\&M (operation and maintenance) cost was assumed to be $\$ 20 / \mathrm{kW}$.

The analysis assumed that either a $138-\mathrm{kV}$ or $69-\mathrm{kV}$ transmission line located on or near Fort Hood would be available to transmit power without substantial additional investment. See the transmission map in Figure F-1 to view potential interconnection locations.

Several years ago, Fort Hood received a proposed to purchase $140 \mathrm{MW}$ of wind from a commercial wind farm located off site. For comparison purposes, a 141-MW wind project using 1.5-MW wind turbines was assumed for the on-site economic assessment. If only the northern portion of Fort Hood is available for development because of siting constraints, this project size may need to be lowered (to 100 MW or less depending on the capacity of the 69-kV lines). Alternatively, additional transmission infrastructure could be constructed at additional cost.

Further details on the analysis methodology and the economic and incentive parameters are documented in Appendix A of this report.

\section{Findings: Wind Energy}

Wind generation is almost economic at Fort Hood. The cost of production is close to the cost of commercial power currently provided by Constellation Energy, and wind generation is likely to become more competitive as commercial electricity costs increase in the future. In making this judgment, the economic hurdle is the $7.9 \$ / \mathrm{kWh}$ energy component of the total $8.5 \$ / \mathrm{kWh}$ electricity price paid by the Fort. The energy component is the appropriate metric because wind energy, being variable on a temporal basis, requires backup power. This means that the Fort must still pay demand charges for its full consumption level, even if little power is being purchase.

This potential Fort Hood wind project is close to being economic under IPP, ECIP and UESC scenarios. IPP projects require at least a $10 \%$ internal rate of return (IRR) after tax to attract private investment (15\% is more representative). At a commercial energy cost of $7.9 \$ / \mathrm{kWh}$, a $140-\mathrm{MW}$ project at Fort Hood would provide a $7.97 \%$ internal rate of return (IRR), which is low, but close to being financeable. At $9.5 \% / \mathrm{kWh}$, the project yields a $10.22 \%$ IRR. ECIP projects require an SIR of 1.25 , while UESC requires payback by life of renewable and SIR $>1.0$. Competing against the $7.9 \$ / \mathrm{kWh}$, the SIR is 1.14 and the payback is 12.6 years.

Note that these analyses assumed that an on-post wind project of $141 \mathrm{MW}$ would not trigger new standby or other fees from the local utility. If it is necessary to wheel power from the northern part of the installation to the cantonment over utility transmission lines, transmission costs will be incurred. The rules for use of utility transmission lines in Texas are being changed for a second time. As a result, it is not clear what these fees may be. The pending changes will charge for transmission use based on 
avoided generation costs during congested periods. This charge could be very high. Because wind is intermittent, power from a wind farm would need to be blended with power from other sources to ensure reliable power to the post. This may complicate power procurement compared to a purchase from a conventional supplier. If a wind project is pursued further, the potential impact of transmission charges and other utility and marketing fees must be included in the economic analysis.

\section{Wind Energy: Next Steps}

Horizon Wind, a wind energy developer working in Texas, was consulted regarding the potential for a project on or near Fort Hood. Horizon Wind has investigated the feasibility of a wind project in an area north of Gatesville, a community just north of Fort Hood. The company erected meteorological towers to determine the wind potential at this site. Horizon is not now actively pursuing the development of the Gatesville project because of other projects in Texas that are demonstrating much higher wind potential.

Transmission constraints are beginning to restrict the delivery of the strong winds of west Texas to the population centers in eastern Texas. This is leading to more developers trying to locate viable wind project sites in parts of Texas outside the outstanding wind areas of West Texas and the Panhandle. Horizon Wind told PNNL that it is very interested in discussions with Fort Hood if Fort Hood is interested in being an off-taker (long-term power buyer) for energy generated just off post, or for developing a wind project on site at Fort Hood.

It makes sense to pursue wind generation projects on post at this time because the current cost of commercial power is only slightly lower than the wind generation projection. One important characteristic of wind power is that its cost is not dependent upon the cost of fossil fuels. Because the cost of fossil-generated energy is expected to increase on a continuing basis, it may be possible to negotiate a fixed-price long-term (20-year) supply contract now that will save considerable money over the term of the contract. The deregulated market in Texas is based on spot market pricing that is difficult to predict. This may add a level of uncertainty in the rates that can be achieved for Fort Hood. This was one of the difficulties associated with the previous wind energy proposal to Fort Hood.

Fort Hood may want to consider the possibility of buying energy off post through a negotiated renewable energy tariff with Constellation Energy, or a partnership with a wind developer for a project located either on post or off post.

\section{Wind Energy References}

3TIER Environmental Forecast Group, Inc., 2008. Firstlook Wind Assessment Map. http://firstlook.3tiergroup.com/wind

Federal Aviation Administration (FAA). 2007. Advisory Circular (AC 70/7460-1K) Obstruction Marking and Lighting. Effective: February 2, 2007.

http://www.airweb.faa.gov/Regulatory_and_Guidance_Library/rgAdvisoryCircular.nsf/0/b993dcdfc37fc dc486257251005c4e21/\$FILE/AC70 7460 1K.pdf

NASA Langley Research Center Atmospheric Science Data Center (NASA. 2007. Last Updated November 12, 2007. http://eosweb.larc.nasa.gov/sse/. 
Pacific Northwest national Laboratory (PNNL). 1986. "Wind Resource Atlas of the United States." http://rredc.nrel.gov/wind/pubs/atlas/

State Energy Conservation Office (SECO). “Texas Tax Code Incentives for Renewable Energy.” http://www.seco.cpa.state.tx.us/re incentives-taxcode-statutes.htm\#171107

Wind Power Today, American Wind Energy Association

http://www.awea.org/pubs/factsheets/WindPowerToday 2007.pdf 
Renewable Energy Opportunities at Fort Hood, Texas Pacific Northwest National Laboratory, June 2008 


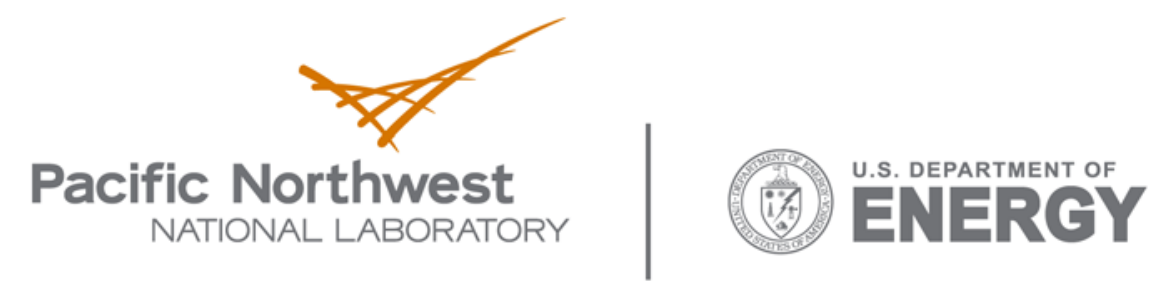

902 Battelle Boulevard

P.O. Box 999

Richland, WA 99352

1-888-375-PNNL (7665)

www.pnl.gov 